HNF-SP-0903

Revision 7

\title{
National Environmental Policy Act Source Guide for the Hanford Site
}

Prepared for the U.S. Department of Energy

Assistant Secretary for Environmental Management

Project Hanford Management Contractor for the

U.S. Department of Energy under Contract DE-AC06-96RL13200

Fluor Hanford

P.O. Box 1000

Richland, Washington 
HNF-SP-0903

Revision 7

\section{National Environmental Policy Act Source Guide for the Hanford Site}

Date Published

September 2000

Prepared for the U.S. Department of Energy

Assistant Secretary for Environmental Management

Project Hanford Management Contractor for the

U.S. Department of Energy under Contract DE-AC06-96RL13200

Fluor Hanford

P.o. Box 1000

Richland, Washington

$\frac{\text { Chris/ Mrillexigham } 7 / 26 / 00}{\text { Date }}$ 
LEGAL DISCLAIMER

This report was prepared as an account of work sponsored by an agency of the United States Government. Neither the United States Government nor any agency thereof, nor any of their employees, nor any of their contractors, subcontractors or their employees, makes any warranty, express or implied, or assumes any legal liability or responsibility for the accuracy. completeness, or any third party's use or the results of such use of any information, apparatus, product, or process disclosed, or represents that its use would not infringe privately owned rights. Reference herein to any specific commercial product, process, or service by trade name, trademark, manufacturer, or otherwise, does not necessarily constitute or imply its endorsement, recommendation, or favoring by the United States Government or any agency thereof or its contractors or subcontractors. The views and opinions of authors expressed herein do not necessarily state or reflect those of the United States Government or any agency thereof.

This report has been reproduced from the best available copy.

Printed in the United States of America 
CONTENTS

TERMS

ix

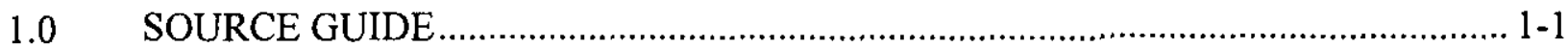

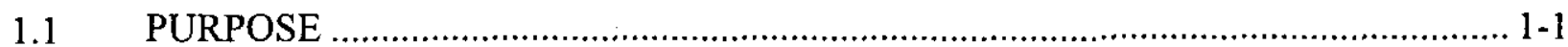

1.2 PERSONAL COMPUTER ACCESS TO INFORMATION ……............................. 1-1

1.3 LIBRARIES ................................................................................................... 1-1

1.4 HISTORY OF NATIONAL ENVIRONMENTAL POLICY ACT

DOCUMENTATION ON THE HANFORD SITE .................................................. 1-1

1.5 NUCLEAR WASTE POLICY ACT OF 1982 ……........................................... 1-2

$2.0 \quad$ ENVIRONMENTAL ASSESSMENTS............................................................. 2-1

DOE/EA-0021 Decommissioning and Decontamination Activity, Hanford Building

Disposal Demonstration Project, REDOX Plutonium Concentration

(233-S) Building ....................................................................................... 2-1

DOE/EA-0030 Operation of N Reactor and Fuels Fabrication Facilities............................. 2-1

DOE/EA-0044 Support Services Building ………….................................................... 2-1

DOE/EA-0048 National Waste Terminal Storage Program, Exploratory Borehole

Drilling Activity ....................................................................................... 2-2

DOE/EA-0052 National Waste Terminal Storage Program, Near-Surface Test Facility....... 2-3

DOE/EA-0102 Steam Generator Tube Integrity Program, Surry Steam Generator Project... 2-4

DOE/EA-0111 Maintenance and Storage Facility............................................................. 2-4

DOE/EA-0116 Fuels and Materials Examination Facility .................................................. 2-5

DOE/EA-0120 100 F Area Decommissioning Program.................................................... 2-6

DOE/EA-0188 Basalt Waste Isolation Project, Exploratory Shaft Construction .................... 2-7

DOE/EA-0210 Characterization of the Hanford Site Pursuant to the Nuclear Waste

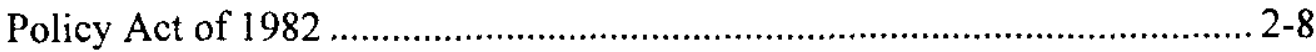

DOE/EA-0258 Breeder Reprocessing Engineering Test (BRET) Facility ............................. 2-8

DOE/EA-0259 Decommissioning of Strontium Semiworks Facility .................................... 2-8

DOE/EA-0312 Grouting and Near-Surface Disposal of Low-Level Radioactive

Phosphate/Sulfate Wastes from N Reactor Operation ................................... 2-9

DOE/EA-0318 SP-100 Ground Engineering System Test Site .......................................... 2-10

DOE/EA-0358 Handling and Transportation of Isotopic Heat Sources .............................. 2-12

DOE/EA-0370 Fast Flux Test Facility Power Addition .................................................... 2-12

DOE/EA-0383 Hanford Environmental Compliance Project............................................... 2-12

DOE/EA-0411 Fuel Assembly Area....................................................................... 2-13

DOE/EA-0429 Environmental and Molecular Sciences Laboratory ................................... 2-13

DOE/EA-0479 Collecting Crust Samples from Level Detectors in Tank SY-101 ............... 2-14

DOE/EA-0495 Preparation for Crust Sampling of Tank 241-SY-101 ............................... 2-15

DOE/EA-0511 Characterization of Tank 24l-SY-101 .................................................. 2-16

DOE/EA-0533 Vapor Space Sampling of Ferrocyanide Tanks ........................................ 2-17

DOE/EA-0535 105-KE and 105-KW Basins Fuel Encapsulation and Repackaging,

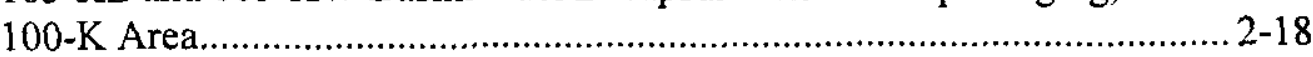




\section{CONTENTS (cont)}

DOE/EA-0538 Storage of Fast Flux Test Facility Unirradiated Fuel in the

PFP Complex

DOE/EA-0581

Upgrading of the Ventilation System at the 241-SY Tank Farm.

2-20

DOE/EA-0582 Expedited Response Action for the 200 West Area Carbon Tetrachloride

Plume

2-20

DOE/EA-0596

Intrusive Sampling and Testing of Ferrocyanide Tanks

$2-21$

DOE/EA-0618

Integrated Voice/Data Telecommunications System.

2-22

DOE/EA-0696

Construction of Temporary Mobile Office Complex, 200 West Area

$2-22$

DOE/EA-0787

Shipment of Low Enriched Uranium Billets to the United Kingdom

$2-23$

DOE/EA-0802

Tank 241-SY-101 Equipment Installation and Operation to Enhance

Tank Safety

$2-24$

DOE/EA-0803

Proposed Pump Mixing Operations to Mitigate Episodic Gas Releases

in Tank 241-SY-101

DOE/EA-0809

Thermocouple Tree System Installation and Operation in Non-Leaking

Ferrocyanide Tanks.

$2-25$

Final RI/FS - EA Report for 1100-EM-1 Operable Unit ......................... 2-26

DOE/EA-0829

Construction and Operation of Particle Accelerator Bio-Physical

Laboratory,

DOE/EA-0881

Tank 241-C-103 Organic Vapor and Liquid Characterization and

Supporting Activities. ......................................................................... 2-26

DOE/EA-0904

Access Road From State Route 240 to the 200 West Area..

$2-27$

DOE/EA-0915

Waste Tank Safety Program

2-27

DOE/EA-0921

DOE/EA-0933

Proposed Relocation and Resumption of DOE Radon Research Program

in the 300 Area.

2-28

Tank 241-C-106 Past-Practice Sluicing Waste Retrieval

2-29

DOE/EA-0942

Return of Isotope Capsules to the Waste Encapsulation and Storage

Facility

DOE/EA-0944

DOE/EA-0959

222-S Radioactive Liquid Waste Line Replacement and

219-S Secondary Containment Upgrade

Resiting, Construction, and Operation of the Environmental and

Molecular Sciences Laboratory . $2-33$

DOE/EA-0978

Sludge Stabilization at the Plutonium Finishing Plant

$2-33$

DOE/EA-0980

DOE/EA-0981

300 Area Process Sewer Piping Upgrade and 300 Area Treated Effluent

Disposal Facility Discharge to the City of Richland Sewage System ........ 2-34

Solid Waste Retrieval Complex, Enhanced Radioactive and Mixed

Waste Storage Facility, Infrastructure Upgrades, and Central Waste

Support Complex

$2-35$

DOE/EA-0982

Special Case Material, Construction and Operation of a Storage Unit.

$2-36$

DOE/EA-0983

DOE/EA-0984

Inert/Demolition Waste Landfill (Pit 9).

$2-37$

Deactivation of the $\mathrm{N}$ Reactor Facilities

$2-38$

DOE/EA-0985

DOE/EA-0986

Relocation and Storage of TRIGA Reactor Irradiated Fuel.

2-40

Project L-116, 200 Area Sanitary Sewer System. 2-40

Disposition of Alkali Metal Test Loops.

2-41 


\section{CONTENTS (cont)}

DOE/EA-0988 Transfer of Plutonium-Uranium Extraction Plant and N Reactor Irradiated Fuel for Storage at the $105-\mathrm{KE}$ and $105-\mathrm{KW}$ Fuel Storage

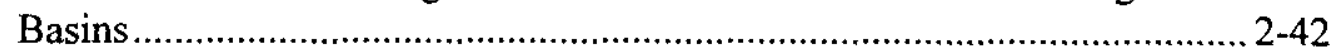

DOE/EA-0992 Decommissioning of Building 233-S, Plutonium Concentration Facility ... 2-43 DOE/EA-0993 Shutdown of Fast Flux Test Facility ....................................................... 2-44 DOE/EA-1005 Disposition and Transportation of Surplus Radioactive Low Specific Activity Nitric Acid. .......................................................................... 2-46

DOE/EA-1030 Characterization of Stored Defense Production Spent Nuclear Fuel and Associated Materials at Hanford Site ......................................................... 2-47

DOE/EA-1098 Decommissioning and Decontamination of Building 232- $Z$ at the

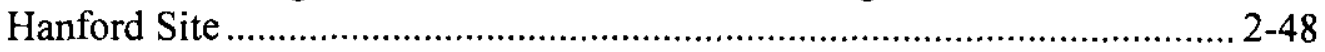

DOE/EA-1111 K Pool Fish Rearing............................................................................ 2-49

DOE/EA-1112 Sludge and Solid Residue Stabilization at the Plutonium Finishing

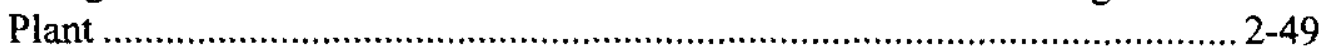

DOE/EA-1123 Transfer of Normal and Low-Enriched Uranium Billets to the United

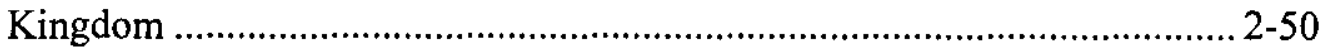

DOE/EA-1135 Offsite Thermal Treatment of Low-Level Mixed Waste ............................ 2-50

DOE/EA-1142 200 West Area Raw Water Line ……....................................................... 2-51

DOE/EA-1177 Salvage/Demolition of 200W, 200E, and 300 Areas Steam Plants ..............2-51

DOE/EA-1178 300 Area Steam Replacement ........................................................ 2-52

DOE/EA-1182 200 Area Emergency Facilities Campus.................................................. 2-52

DOE/EA-1185 Management of Hanford Site Non-Defense Production Reactor Spent

Nuclear Fuel....................................................................................... 2-52

DOE/EA-1189 Solid Low-Level Waste (LLMW) Non-Thermal Treatment ........................ 2-53

DOE/EA-1203 Trench 33 Widening in 218-W-5 Low-Level Burial Ground ...................... 2-53

DOE/EA-1210 Lead Test Assembly Irradiation and Analysis, Watts Bar Nuclear Plant .... 2-53

DOE/EA-1211 Relocation and Storage of Isotopic Heat Sources...................................... 2-54

DOE/EA-1259 WPPSS (Supply System) Sublease for an Aluminum Smelter Plant .......... 2-54

DOE/EA-1260 Transfer of 1100 Area, Southern Rail Connection, and Rolling Stock ....... 2-54

DOE/EA-1276 Widening Trench 36 of the 218-E-12B Low-Level Burial Ground ............. 2-54

DOE/EA-1319 Disposition of Surplus Hanford Site Uranium............................................ 2-55

3.0 MISCELLANEOUS ENVIRONMENTAL ASSESSMENTS ….............................. 3-1

DOE/RW-0070 Reference Repository Location................................................................ 3-1

EIA/WPR/77-3 Environmental Impact Assessment: Coring Well ......................................... 3-1

RHO-BWI-CD-19-REV Constructing a Near-Surface Test Facility ...................................... 3-2

4.0 U.S. ATOMIC ENERGY COMMISSION, ENVIRONMENTAL STATEMENTS (WASH) - HANFORD SITE ..................................................................................... 4-1

WASH-1510

WASH-1520

WASH-1521
Fast Flux Test Facility, U.S. Atomic Energy Commission............................. 4-1

Contaminated Soil Removal Facility, U.S. Atomic Energy Commission..... 4-2

Radioactive Waste Evaporator and Auxiliaries, U.S. Atomic Energy

Commission 4-3 


\section{CONTENTS (cont)}

5.0 U.S. ENERGY RESEARCH AND DEVELOPMENT ADMINISTRATION

EVIRONMENTAL IMPACT STATEMENTS - HANFORD SITE .......................... 5-1

ERDA-1538

ERDA-1550

ERDA-1556
Waste Management Operations $5-1$

Final Environmental Impact Statement: High-Performance Fuel Laboratory. $5-2$

High-Flux Neutron Source Facility, Hanford Reservation
DOE/EIS-0017

DOE/EIS-0046

DOE/EIS-0063

DOE/EIS-0080

DOE/EIS-0089

DOE/EIS-0113

DOE/EIS-0115

DOE/EIS-0119

DOE/EIS-0189

DOE/EIS-0200

DOE/EIS-0203

DOE/EIS-0212

DOE/EIS-0222

DOE/EIS-0229

DOE/EIS-0244

DOE/EIS-0245

DOE/EIS-0250

DOE/EIS-0259

DOE/EIS-0276

DOE/EIS-0283

DOE/EIS-0285

DOE/EIS-0286

DOE/EIS-0287

DOE/EIS-0306
Fusion Materials Irradiation Testing Facility

Management of Commercially Generated Radioactive Waste

Waste Management Operations, Double-Shell Tanks for Defense

High-Level Radioactive Waste Storage

Decommissioning of the Shippingport Atomic Power Station.................... 6-5

Addendum: Operation of PUREX and Uranium Oxide Plant Facilities.

Disposal of Hanford Defense High-Level, Transuranic and Tank Waste

Process Facility Modifications Project 6-13

Decommissioning of Eight Surplus Production Reactors at the

Hanford Site 6-14

Tank Waste Remediation System 6-16

Office of Environmental Management Programmatic Environmental Impact Statement (PEIS).

Programmatic Spent Nuclear Fuel Management and Idaho National

Engineering Laboratory Environmental Restoration and Waste

Management Programs

Safe Interim Storage of Hanford Tank Wastes 6-22

Hanford Comprehensive Land-Use Plan Environmental Impact

Statement.

Storage and Disposition of Weapons Usable Fissile Materials

Plutonium Finishing Plant, 200 West Area

Management of Spent Nuclear Fuel From the K-Basins at the Hanford Site

Geologic Repository for the Disposal of Spent Nuclear Fuel and

High-Level Radioactive Waste at Yucca Mountain

Disposal of Decommissioned, Defueled Cruiser, Ohio Class, and

Los Angeles Class Naval Reactor Plants

Interim Storage of Plutonium at the Rocky Flats Environmental

Technology Site $6-32$

Surplus Plutonium Disposition 6-32

Transmission System Vegetation Management Program

Hanford Site Solid Waste (Radioactive \& Hazardous) Program EIS ......... 6-33

Idaho High-Level Waste and Facilities Disposition..... $6-33$

Treatment and Management of Sodium-Bonded Spent Nuclear Fuel 
HNF-SP-0903, Rev. 7

\section{CONTENTS (cont)}

DOE/EIS-0310 Programmatic Environmental Impact Statement for Accomplishing Expanded Civilian Nuclear Energy Research and Development and Isotope Production Missions in the United States, Including the Role of the Fast Flux Test Facility 6-34

SEPA EIS Commercial Low-Level Radioactive Waste Disposal Site on the Hanford Site 6-35

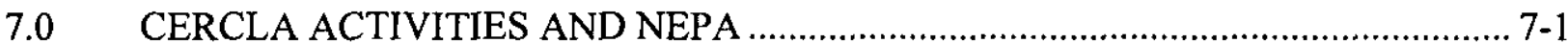

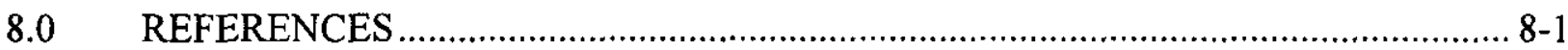


HNF-SP-0903, Rev. 7

This page intentionally left blank. 


\section{TERMS}

\begin{tabular}{|c|c|}
\hline $\begin{array}{l}\text { AEC } \\
\text { ALARA } \\
\text { ATG } \\
\text { BHI } \\
\text { BPA } \\
\text { BWIP }\end{array}$ & $\begin{array}{l}\text { U.S. Atomic Energy Commission } \\
\text { as low as reasonably achievable } \\
\text { Allied Technology Group, Inc. } \\
\text { Bechtel Hanford, Inc. } \\
\text { Bonneville Power Administration } \\
\text { Basalt Waste Isolation Project }\end{array}$ \\
\hline $\begin{array}{l}\text { CEQ } \\
\text { CERCLA } \\
\text { CH }\end{array}$ & $\begin{array}{l}\text { Council on Environmental Quality } \\
\text { Comprehensive Environmental Response, Compensation, and Liability Act of } 1980 \\
\text { contact handled }\end{array}$ \\
\hline $\begin{array}{l}\text { D\&D } \\
\text { DOE } \\
\text { DOE-HQ } \\
\text { DOT } \\
\text { DST }\end{array}$ & $\begin{array}{l}\text { decontamination and decommissioning } \\
\text { U.S. Department of Energy } \\
\text { U.S. Department of Energy, Headquarters } \\
\text { U.S. Department of Transportation } \\
\text { double-shell tank }\end{array}$ \\
\hline $\begin{array}{l}\text { EA } \\
\text { Ecology } \\
\text { EIA } \\
\text { EIS } \\
\text { EMSL } \\
\text { EPA } \\
\text { ERDA }\end{array}$ & $\begin{array}{l}\text { environmental assessment } \\
\text { Washington State Department of Ecology } \\
\text { environmental impact assessment } \\
\text { environmental impact statement } \\
\text { Environmental and Molecular Sciences Laboratory } \\
\text { U.S. Environmental Protection Agency } \\
\text { U.S. Energy Research and Development Administration }\end{array}$ \\
\hline $\begin{array}{l}\text { FFTF } \\
\text { FH } \\
\text { FMEF } \\
\text { FONSI } \\
\text { FY } \\
\text { FR }\end{array}$ & $\begin{array}{l}\text { Fast Flux Test Facility } \\
\text { Fluor Hanford } \\
\text { Fuels and Materials Examination Facility } \\
\text { finding of no significant impact } \\
\text { fiscal year } \\
\text { Federal Register }\end{array}$ \\
\hline $\begin{array}{l}\text { HEPA } \\
\text { HFNS } \\
\text { HLW } \\
\text { HPFL } \\
\text { HWVP }\end{array}$ & $\begin{array}{l}\text { high-efficiency particulate air (filter) } \\
\text { High-Flux Neutron Source (Facility) } \\
\text { high-level waste } \\
\text { High-Performance Fuel Laboratory } \\
\text { Hanford Waste Vitrification Plant }\end{array}$ \\
\hline $\begin{array}{l}\text { LFL } \\
\text { LLW } \\
\text { LMFBR }\end{array}$ & $\begin{array}{l}\text { lower flammability limit } \\
\text { low-level waste } \\
\text { liquid metal fast breeder reactor }\end{array}$ \\
\hline $\begin{array}{l}\text { MASF } \\
\text { mrem } \\
\text { MWt }\end{array}$ & $\begin{array}{l}\text { Maintenance and Storage Facility } \\
\text { millirem } \\
\text { megawatt thermal }\end{array}$ \\
\hline
\end{tabular}




\section{TERMS (cont)}

$\begin{array}{ll}\text { NEPA } & \text { National Environmental Policy Act of } 1969 \\ \text { NRC } & \text { U.S. Nuclear Regulatory Commission } \\ \text { NSTF } & \text { near-surface test facility } \\ \text { NWPA } & \text { Nuclear Waste Policy Act of } 1982 \\ \text { PFM } & \text { process facility modification } \\ \text { PFP } & \text { Plutonium Finishing Plant } \\ \text { PNL } & \text { Pacific Northwest Laboratory } \\ \text { PNNL } & \text { Pacific Northwest National Laboratory } \\ \text { PUREX } & \text { Plutonium-Uranium Extraction (Facility) } \\ \text { R\&D } & \text { research and development } \\ \text { RCRA } & \text { Resource Conservation and Recovery Act of 1976 } \\ \text { rem } & \text { roentgen equivalent man } \\ \text { ROD } & \text { record of decision } \\ & \\ \text { SST } & \text { single-shell tank } \\ \text { TCT } & \text { thermocouple tree } \\ \text { TEDF } & \text { Treated Effluent Disposal Facility } \\ \text { TRU } & \text { transuranic (waste) } \\ & \\ \text { UO3 } & \text { Uranium-Trioxide (Plant) } \\ \text { USQ } & \text { unreviewed safety question } \\ \text { WASH } & \text { Washington, D.C. } \\ \text { WHC } & \text { Westinghouse Hanford Company } \\ \text { WIPP } & \text { Waste Isolation Pilot Plant }\end{array}$




\subsection{SOURCE GUIDE}

This Source Guide will assist those working with the National Environmental Policy Act (NEPA) of 1969 to become more familiar with the environmental assessments (EA) and environmental impact statements (EIS) that apply to specific activities and facilities on the Hanford Site. This document should help answer questions concerning NEPA coverage, history, processes, and the status of many of the buildings and units on and related to the Hanford Site.

\subsection{PURPOSE}

This document summarizes relevant EAs and EISs by briefly outlining the proposed action of each document and the decision made by the U.S. Department of Energy (DOE) or its predecessor agencies, the U.S. Atomic Energy Commission (AEC) and the U.S. Energy Research and Development Administration (ERDA). The summary includes the proposed action alternatives and current status of the proposed action. If a decision officially was stated by the DOE, as in a finding of no significant impact (FONSI) or a record of decision (ROD), and the decision was located, a summary is provided. Not all federal decisions, such as FONSIs and RODs, can be found in the Federal Register (FR). For example, although significant large-action FONSIs can be found in the FR, some low-interest FONSIs might have been published elsewhere (i.e., local newspapers).

The EA and EIS summaries are arranged in numerical order. The EAs with nonstandard numbering schemes are located in Chapter 3.0.

\subsection{PERSONAL COMPUTER ACCESS TO INFORMATION}

An electronic copy of the NEPA Source Guide is available on the HLAN Hanford Information. A hard copy of this document is available for public reading at the Pacific Northwest National Laboratory (PNNL) Technical Library (509 376-1606), Resource Library (509 372-7303), and at the Environmental Resource Center (509 372-9259). DOE's NEPA Web Site may be found at http://tis.eh.doe.gov/nepa.

\subsection{LIBRARIES}

The PNNL Technical Library, located in the 300 Area, has Hanford Site EAs and EISs on file. The NEPA organizations in Fluor Hanford (FH) and PNNL can assist in locating specific documents or could maintain files of lower-tiered NEPA documents such as categorical exclusions and memorandum to files.

\subsection{HISTORY OF NATIONAL ENVIRONMENTAL POLICY ACT DOCUMENTATION ON THE HANFORD SITE}

The AEC was the first agency to prepare EISs and EAs on the Hanford Site. Originally, the EISs were called environmental statements and EAs were known as environmental impact assessments. When the AEC was reorganized and replaced by the ERDA, the EISs and EAs became ERDA documents. Similarly, when the ERDA became part of the DOE, the EISs and EAs became DOE documents. Before 1978, the EA and EIS process did not culminate in FONSIs or RODs. In 1978, the Council on Environmental Quality (CEQ) published NEPA regulations requiring FONSIs and RODs for these documents. The DOE formally adopted these regulations in July 1979. 
A comprehensive list of all the EISs and EAs published as AEC, ERDA, and DOE documents is available from the DOE Office of NEPA Oversight in Washington, D.C., telephone (202) 896-0125. A complete listing for each document includes the DOE number, title, relevant dates, DOE facility, status, and comments.

The documents identified as draft have not been finalized or were cancelled. Draft documents do not have an official status; therefore, these are referenced as predecisional.

\subsection{NUCLEAR WASTE POLICY ACT OF 1982}

The NWPA specifies the process for selecting a repository site and gives this responsibility to the DOE. Congress approved geologic disposal by declaring that one of the key purposes of the Act is "to establish a schedule for the citing, construction, and operation of repositories that will provide reasonable assurance that the public and the environment will be adequately protected from the hazards posed by high-level waste (HLW) and other such spent nuclear fuel as may be disposed of in a repository." All documents associated with the NWPA and the Hanford Site can be found in Chapter 3.0. Some specific NWPA activities are exempt from the requirements for the NEPA. 


\subsection{ENVIRONMENTAL ASSESSMENTS}

This chapter provides summary information for EAs.

DOE/EA-0021 Decommissioning and Decontamination Activity, Hanford Building Disposal Demonstration Project, REDOX Plutonium Concentration (233-S) Building, Hanford Site, Richland, Benton County, Washington

Background: This EA proposed to decontaminate, dismantle, and decommission a retired nuclear process facility. The Reduction Oxidation Plant Plutonium Concentration Building (233-S) in the 200 West Area was selected as the first demonstration project under the DOE program for disposition of retired contaminated facilities on the Hanford Site.

The project would include decontamination and removal of all building equipment. The building surfaces and shell would be decontaminated to the point where demolition could proceed with minimal expense, with the option of leaving the structure standing and available for other use.

All equipment that could not be decontaminated to acceptable levels would be sealed and placed in a retrievable storage trench designated for transuranic (TRU)-contaminated waste. If the 233-S Building were dismantled, contaminated rubble also would be stored in this trench.

FONSI: $\quad$ The FONSI was not required because the EA was written before the CEQ's final regulations were issued.

Current Status: Soon after the EA was drafted, the DOE determined that the EA would not be finalized, and the EA was canceled In 1992, it was determined that D\&D of the 232-Z Waste Incineration Facility (refer to DOE/EA-0992) would be considered, together with the 233-S Building, in a single document In late 1995, however, a decision was made to address the two facilities in separate EA's (DOE/EA-0992 addresses 233-S, and DOE/EA-1098 addresses 232-Z) because the decommissioning schedules of the two facilities diverged. Please refer to DOE/EA-0992 for status of 233-S decision documentation and the D\&D efforts.

DOE/EA-0030 Operation of N Reactor and Fuels Fabrication Facilities, Hanford Reservation, Richland, Washington, draft.

The EA was abandoned and never finalized.

DOE/EA-0044

Support Services Building, Hanford Reservation, Richland, Washington, July 1978.

Background: This EA proposed construction of a permanent building, the Support Services Building (designated the 4713-B Building), to provide central maintenance shops for nonradioactive equipment; offices; and other administrative support facilities (e.g., conference rooms and a lunchroom). The building would be located in the 400 Area 
of the Hanford Site. The building was scheduled to be completed by the first quarter of fiscal year (FY) 1982. Anticipated design life for the building was to be 20 years.

FONSI: $\quad$ A FONSI was not required because the EA was written before the CEQ's final regulations were issued.

Current Status: The facility was constructed and is operating under the mission stated in the EA.

DOE/EA-0048 National Waste Terminal Storage Program, Exploratory Borehole Drilling Activity, Hanford Reservation, Richland, Washington, June 1978.

Background: $\quad$ This EA proposed drilling five boreholes on the Hanford Site to collect data on in situ rock formations. The project was part of the National Waste Storage Program to find potentially suitable nuclear waste repositories. The five boreholes were to be drilled to obtain subsurface geologic and hydrologic information. The holes would range from 1,160 to 1,525 meters $(3,805$ to 5,002 feet $)$ deep.

Three drilling sites were selected. Site 1 would contain boreholes ARH-DC-4 and ARH-DC-5, approximately 2.4 kilometers ( 1.5 miles) west of the 200 West Area. Site 2 would contain borehole ARH-DC-6, approximately 8 kilometers $(5.0$ miles) east of Gable Mountain near the old Hanford townsite. Boreholes ARH-DC-7 and ARH-DC-8 would be in Site 3 just southeast of the Wye Barricade.

Two different types of boreholes were proposed. Stratigraphic boreholes (ARH-DC-4, ARH-DC-6, and ARH-DC-8) were primarily intended to provide core samples of the various subsurface geologic formations. Hydrologic boreholes (ARH-DC-5 and ARH-DC-7) were primarily intended to provide information on subsurface aquifers.

Special Notice: An EA on exploratory borehole ARH-DC-2 was prepared by the ERDA and assigned the ERDA document control number EIA/WPR/77-3. In addition, the ERDA Assistant Administrator for Environment and Safety determined that an EA was not necessary for exploratory borehole ARH-DC-3, based on the proximity of the borehole to ARH-DC-2 and the EA on borehole ARH-DC-2.

FONSI: $\quad$ A FONSI was not required because the EA was written before the CEQ's final regulations were issued.

Current Status: Borehole ARH-DC-4 was plugged August 5, 1988; the reclamation was completed August 19, 1988. Borehole ARH-DC-5 was plugged July 12, 1988; the reclamation was completed August 1, 1988.

Borehole ARH-DC-6, originally scheduled for abandonment, was reconfigured following a review and concurrence of the recommended change by the Washington State Department of Ecology (Ecology) and was transferred to the PNL. This borehole was retained to support future onsite studies.

Borehole ARH-DC-7 was plugged September 15, 1988; the reclamation was completed September 29, 1988. Borehole ARH-DC-8 was plugged September 22, 1988; the reclamation was completed September 30, 1988. 
DOE/EA-0052 National Waste Terminal Storage Program, Near-Surface Test Facility, Hanford Reservation, Richland, Washington, December 1978.

Background: $\quad$ This EA proposed building a Near-Surface Test Facility (NSTF) to support the Basait Waste Isolation Project (BWIP). The facility would provide the capability for in situ testing of basalt on the Hanford Site to produce data necessary to determine if the basalt was suitable as a commercial radioactive waste repository. The EA proposed mining a portion of the selected underground basalt flow in Gable Mountain, conducting electrical (non-nuclear) heater tests and commercial spent fuel tests for a period of 3 years each, and decommissioning the test facility.

The data obtained from the electrical heater tests and the spent fuel tests would provide information to assist in determining if basalt was suitable as a radioactive waste repository.

The facility would contain approximately 1,000 meters $(3,280$ feet $)$ of underground workings, including three access tunnels, two test rooms, an instrumentation room, and a computer room. Phase I of the tests was to develop the electrical heater test portion of the facility and was scheduled for completion by late 1979. Work on Phase II, the spent fuel test portion, was scheduled for completion by late 1980 .

The construction site for the test facility would be near the site of exploratory borehole ARH-DC-11. An open cut, approximately 15 meters ( 49 feet) deep and 15 meters ( 49 feet) wide, would be made for each of the three portals of the facility to allow access to the Pomona basalt flow. The horizontal access tunnels at the west end of the facility would serve as entrances to the two test areas. The east access tunnel would be used for ventilation purposes and as an emergency exit. Isolation from the environment would be maintained by keeping the Phase II test area at a negative pressure and installing exclusion doors at both ends of the test area.

Following the completion of the 3 year electrical heater and spent fuel tests, decommissioning would begin. The canistered spent fuel would be removed from the NSTF and shipped back to the Engine Maintenance and Disassembly Facility at the Nevada Test Site. Test decommissioning would include removal of test hardware, wiring, and the protective coverings on the test holes. Facility decommissioning would include removal of facility fittings, backfilling the entrance and exit portals with previously mined rock, and restoring the site.

The NSTF would complement efforts to characterize the geologic and hydrologic properties of basalt formations on the Hanford Site. There were five boreholes planned for FY 1978 that obtained information from basalt formations as deep as 465 meters (1,525 feet) underground. The five boreholes (ARH-DC-4, ARH-DC-5, ARH-DC-6, ARH-DC-7, and ARH-DC-8) were designed to provide geologic and hydrologic information and could not be used to obtain information on in situ thermal properties of the basalt formations these penetrated. The NSTF exploratory boreholes ARH-DC-10 and ARH-DC-11 on Gable Mountain would provide specific information about the basalt flows in Gable Mountain.

FONSI: $\quad$ A FONSI was not required because the EA was written before the CEQ's final regulations were issued. 
Current Status: The NSTF was constructed and operated, but all activities at the NSTF were terminated with cancellation of the BWIP. All facility equipment has been removed. Borehole ARH-DC-11 and the NSTF were backfilled with crushed material, and concrete bulkheads were installed.

The exploratory borehole (ARH-DC-10), which was drilled in 1978, was not backfilled. Construction of the NSTF Trailer Village in 1979 resulted in the removal of the collar casing from borehole ARH-DC-10, and alteration of the borehole site. During the summer of 1988 , an excavation attempt to locate the borehole was unsuccessful. A hydrologic evaluation of the subsurface groundwater flow in the vicinity of borehole ARH-DC-10 revealed a natural commingling of the unconfined and confined aquifers in the Gable Gap area. As a result of this naturally occurring erosional window, the impact of leaving borehole ARH-DC-10 open was minimal. This evidence was presented to Ecology for evaluation, resulting in a waiver issued on July 21,1989 , which stated that borehole ARH-DC- 10 could be abandoned in its present condition.

\section{DOE/EA-0102 Steam Generator Tube Integrity Program, Surry Steam Generator Project, Hanford Site, Richland, Washington, March 1980.}

Background: This EA proposed constructing and operating a 150-square meter (1,614-foot) facility, now known as the 377 Building in the 300 Area, to house and conduct extensive investigation of a degraded, out-of-service steam generator from a commercial nuclear power plant. This testing program was intended to provide the U.S. Nuclear Regulatory Commission (NRC) with information regarding the integrity and degradation of the pressurized water reactor primary system.

FONSI: $\quad$ A FONSI was approved March 27, 1980, and published in the FR April 2, 1980 (45 FR 21676).

The following actions were included in the FONSI:

- The transportation of a defective steam generator by oceangoing barge from the Virginia Electric Power Company Surry Nuclear Power Station in Virginia to the DOE Hanford Site.

- The construction of a temporary storage facility for the generator and a steam generator examination facility.

- The performance of various research operations on the steam generator to determine why it failed in service.

Current Status: The 377 Building has been decontaminated and, as of August 1980, is vacant.

DOE/EA-0111 Maintenance and Storage Facility, Hanford Site, Richland, Washington, May 1980.

Background: $\quad$ This EA proposed to build the Maintenance and Storage Facility (MASF), now known as the 437 Building, as a multipurpose service center to support the specialized maintenance needs of the 400 Area facilities. The MASF provided 
sodium removal from, and storage of, nonfuel components for the Fast Flux Test Facility (FFTF) and provided decontamination, repair, and storage of the FFTF maintenance support equipment and operational support equipment.

The MASF would be a concrete and steel structure located in the 400 Area. Approximately 2,080 square meters (22,380 feet) of storage, repair, and process space are serviced by a 60 -ton overhead crane with a hook height of 9 meters ( 29.5 feet). An additional 780 square meters $(8,393$ feet) house process equipment, a liquid waste loadout facility, and personnel support facilities.

The facility was designed for a 25-year operating cycle. The number of personnel working in the facility ranges from 17 (normal complement) to a maximum of 45 personnel during periods of major maintenance and refueling of the FFTF.

Waste from the MASF included radioactive liquids from sodium removal and cleaning, radioactive and nonradioactive solid waste, process and sanitary waste water, and exhaust air. Process and sanitary water are treated and released to the 400 Area ponds. The radioactive liquids and the radioactive and nonradioactive solid waste are handled as described in the EIS (Chapter 5.0, ERDA-1538). No operations involving nuclear fuel or TRU were planned for the MASF.

The project's proposed cost was approximately $\$ 16.7$ million and construction started in FY 1982.

FONSI:

A FONSI is not available; this EA was completed before the CEQ's final regulations were issued in 1980 .

Current Status: The MASF was built as described in the proposed action and is operational. It is being used to support Tank Farms operations' testing.

DOE/EA-0116 Fuels and Materials Examination Facility,

Hanford Site, Richland, Washington, July 1980.

Background: This EA proposed providing the Fuels and Materials Examination Facility (FMEF) with fuel development, fuel fabrication, and irradiated fuel and materials examination capabilities in support of the FFTF and other reactors in the liquid metal fast breeder reactor (LMFBR) program. The FMEF (or 427 Building) would have had approximately 15,793 square meters (169,932 feet) of floor space and was to be located in the 400 Area of the Hanford Site.

The FMEF was to contain laboratory space and facilities to support the development of radioactive fuel fabrication processes, equipment, and handling systems. Laboratory space also was to be provided for fabrication of the FFTF and the LMFBR fuel experiments, and to accommodate the radioactive analytical functions that supported fuel fabrication activities. Post-irradiation examination activities would have been carried out mainly in a centrally located shielding cell complex. This cell complex was to have capabilities for both nondestructive and destructive examination, as well as equipment for disassembly and reassembly of fuel and other reactor core component assemblies. A ground-level entry wing would have provided offices, a lunchroom, a change room, and other support facilities to the operation staff and security personnel. 
FONSI:

Current Status:

Background:
The FONSI was approved July 14, 1980.

The following actions were included in the FONSI:

- The proposed facility had fuel development, fabrication, and examination capabilities in support of the FFTF and other reactors in the LMFBR program, and would have been equipped to receive special nuclear material in powder form; prepare feed stock; analyze fuels and fuel materials; fabricate test fuel pins; and develop fuel manufacturing processes, equipment, and handling systems to meet established safeguards, security, and environmental criteria.

- The proposed facility was equipped to receive; clean; nondestructively examine; and disassemble irradiated fuels, materials, and core components from the FFTF and other LMFBRs. The proposed facility also was to be equipped to receive nondestructively and destructively examined individual fuels, blanket, and absorber pins; and reassembled selected fuel assemblies or other materials for additional irradiation after nondestructive examination.

- The proposed facility was designed to contain all radioactivity in the event of a design-basis tornado or design-basis earthquake.

- All exhaust gases were to be filtered before being released. Exhaust gases from cells and gloveboxes would have passed through a series of three high-efficiency particulate air (HEPA) filters, while exhaust gases from areas containing irradiated fuel material would have passed through HEPA filters and activated charcoal filters. The estimated maximum dose rate at the 400 Area boundary from releases during normal operations of the facility would have been approximately $2.9 \times 10-8$ millirem (mrem) per hour to the whole body, which would have been negligible when compared to natural background radiation levels of about 0.01 mrem per hour.

- The environmental effects of disposal of all radioactive and nonradioactive waste would have been negligible and would not have affected the conclusions reached in ERDA-1538 (refer to Chapter 5.0).

After issuance of the FONSI, a modification to the original mission was addressed in a supplement to DOE/EA-0116. The FMEF Environmental Assessment Supplement for Secure Automated Fabrication (SAF) was issued October 30, 1981.

Construction of the FMEF has been completed. However, proposed activities in the facility have not been performed. The facility has been, and is being, considered for multiple missions. Those missions include fuel fabrication and medical isotope production.

100 F Area Decommissioning Program, Hanford Site, Richland, Washington, October 1980.

The DOE proposed to decommission the 100-F Reactor Area on the Hanford Site. The 100-F Reactor decommissioning program was a full-scale D\&D demonstration project to remove or stabilize all radioactive materials in the $100-\mathrm{F}$ Area. 
FONSI:

Current Status:

DOE/EA-0188

Background:
The FONSI was published in the FR August 22, 1980 (45 FR 56125).

The following actions were included in the FONSI:

- Complete decontamination and dismantling of the 105 Building (the retired $F$ Reactor building), the 115 and 117 Buildings (ancillary buildings near the reactor), the 107-F Retention Basin and 116-F2 Liquid Waste Trench, and the 100-F and 141-C Buildings (biology buildings). In addition, six radioactive solid waste burial grounds and seven contaminated liquid waste disposal facilities (cribs and trenches) in the 100-F Area were isolated in place or, in a few cases, exhumed for removal to more suitable burial grounds.

- All contaminated material resulting from the decommissioning activity was transported within the controlled area of the Hanford Site by truck or rail to approved disposal facilities in the 200 Area. Approximately 454,248 liters ( 120,012 gallons) of contaminated liquid were transported to the 200 West Area by 75,708 -liter $(20,000$-gallon) railway tank cars for evaporation to a solid state and subsequent in-tank storage.

Contaminated waste (approximately 2,830 cubic meters [ 100,000 cubic feet] each year during each of the 4 years of decommissioning) was transported to the 200 Areas.

As of May 1993, the entire 100-F Area was D\&D'd except for the 105-F Building (reactor), the 107-F Retention Basin, and the 108-F Building (biology laboratory). The decommissioning of the 105-F Building has been covered by the EIS for decommissioning of eight surplus production reactors on the Hanford Site [DOE/EIS-0119(F), Chapter 6]. The 108-F Building was scheduled to be decommissioned in 1993. The schedule for decommissioning the 107-F Retention Basin has not been decided. There has not been any activity since 1992. Cocooning on the 105-F tentatively is scheduled for the year 2003.

Basalt Waste Isolation Project, Exploratory Shaft Construction, Hanford Site, Richland, Benton County, Washington, September 1982.

This EA proposed to excavate an exploratory shaft for the BWIP. The BWIP was to be used by the National Waste Terminal Storage Program organization to conduct studies to assess the feasibility of safe geologic disposal of commercial nuclear HLW in basalt formations.

Detailed site studies would be conducted on the Hanford Site through the construction of an exploratory shaft. This EA described the environmental effects expected to result from construction of this shaft. Other activities would have been to characterize the site, such as seismic surveys and underground testing at the base of the shaft, but were determined not to have potential for significant environmental impacts; and, therefore, were not covered in this EA.

The proposed site for the exploratory shaft was located within the area identified for the potential repository, an approximately 47-square-kilometer (18-square-mile) portion about 1.6 kilometers (1 mile) west of the 200 West Area. 
FONSI: $\quad$ The FONSI was published in the FR September 16, 1982 (47 FR 40820).

The following actions were included in the FONSI:

- Construct an exploratory shaft.

- Gather information about the site to aid in evaluating the suitability of the site for use as a nuclear waste repository.

Current Status: The BWIP project was terminated in 1987. The BWIP exploratory shaft was filled with concrete and the surface area around the shaft was replanted with vegetation. No other work has occurred at the site.

DOE/EA-0210 Characterization of the Hanford Site Pursuant to the Nuclear Waste Policy Act of 1982,

Richland, Washington, February 1983.

This is a NWPA document. This EA was revised and became DOE/RW-0070 (refer to Section 3.0).

DOE/EA-0258 Breeder Reprocessing Engineering Test (BRET) Facility,

Hanford Site, Richland, Washington, draft.

The EA was abandoned and never finalized for review and approval by DOE.

DOE/EA-0259 Decommissioning of Strontium Semiworks Facility,

Hanford Site, Richland, Washington, May 1985.

Background: This EA proposed that the Strontium Semiworks Complex be decommissioned to significantly reduce both the potential radiological hazard and the costs of continuing surveillance and maintenance. The Strontium Semiworks Complex is located in the 200 East Area of the Hanford Site. This facility was last used for processing radioactive materials in 1967. From 1967 to 1985, the facilities were maintained in a safe storage mode that required routine surveillance and maintenance.

The Strontium Serniworks Complex included 11 structures. The main structure is the 201-C Process Building, which is made up of three concrete cells in which radionuclides were processed and two other concrete cells for storage and loadout of the product. Attached to the 201-C Process Building were sample and pipe galleries, a maintenance shop, and treatment facilities for process water and air. Other structures in the complex included a solvent handling building, a ventilation system, and underground storage tanks. The proposed decommissioning method for the 201-C Process Building called for demolition of the service galleries and B-Cell to an abovegrade 3 -meter (10-foot) elevation. The remaining service galleries and cells would then be filled with concrete and the site covered with an earthen barrier. Alternatives for the remaining 10 structures were limited to the choice of "no-action" or various degrees of $D \& D$. 
FONSI:

Current Status:
The FONSI was approved May 15, 1985.

The following actions were included in the FONSI:

- Decontaminate three of the buildings and return these to beneficial use.

- Dismantle and demolish the aboveground ancillary structures and entomb the belowground structures with concrete.

- Demolish the main process building to less than or equal to 3 meters ( 10 feet) abovegrade and fill with concrete and rubble.

- Cover all entombed facilities with an engineered earthen barrier equivalent to 5 meters ( 15 feet) of clean soil and stabilize with vegetation.

As of May 1993, the decommissioning of the Strontium Semiworks Facility was partially completed, with the remainder of the cleanup included in later Comprehensive Environmental Response, Compensation, and Liability Act of 1980 (CERCLA) remediation activities.

DOE/EA-0312 Grouting and Near-Surface Disposal of Low-Level Radioactive Phosphate/Sulfate Wastes from $N$ Reactor Operation, Hanford Site, Richland, Washington, December 1986.

Background: This EA proposed that liquid radioactive phosphate and sulfate low-level waste (LLW) generated from $\mathrm{N}$ Reactor operations be disposed in near-surface concrete vaults using cementitious grout. The waste disposal operations would be performed in the 200 East Area of the Hanford Site.

The proposed action was to solidify this waste by mixing the waste with cementitious dry materials (cement, flyash, and clays) to form a grout slurry. The grout slurry would be pumped to vaults located at a near-surface disposal site in the 200 East Area. After the grout solidified, the vaults would be covered with approximately 5 meters ( 15 feet) of soil. The alternative to solidification was continued storage in DSTs.

Analyses of the potential operational and long-term effects of the grout disposal indicated that radionuclide dose rates and chemical releases would be below regulatory limits with no significant adverse health or environmental impacts.

FONSI: $\quad$ The FONSI was approved November 21, 1986.

The following actions were included in the FONSI:

- The two types of liquid LLW generated during $\mathrm{N}$ Reactor operations would be solidified by mixing the waste with cementitious dry materials (cement, flyash, and clays) to form a grout slurry.

- The grout slurry would be pumped into covered vaults located at a near-surface disposal site in the 200 East Area, where the slurry would solidify. 
- After the grout slurry solidified, the vaults would be covered with 5 meters (15 feet) of soil.

- The vault disposal would be designed to meet all Resource Conservation and Recovery Act of 1976 (RCRA) requirements.

- The proposed action to dispose of phosphate and sulfate waste could result in some minor releases of radionuclides to the atmosphere. The total body dose to a maximally exposed offsite individual for routine operations was estimated to be $3 \times 10-12$ mrem for a 1 year dose and $1 \times 10-10$ mrem for a 50-year dose.

Current Status: The Grout Treatment Facility and the phosphate-sulfate waste vault were constructed. The proposed action to fill the vault with grout slurry and solidify the waste was completed in accordance with the FONSI. No further activities have been conducted.

\section{DOE/EA-0318}

Background:

\section{SP-100 Ground Engineering System Test Site, Hanford Site, Richland, Washington, December 1988.}

This EA proposed modifying an existing reactor containment building (decommissioned Plutonium Recycle Test Reactor in the 309 Building) to provide ground-test capability for the prototype SP-100 Reactor. The 309 Building is located in the 300 Area on the Hanford Site.

The DOE, the National Aeronautics and Space Administration, and the U.S. Department of Defense entered into an agreement to jointly develop and fund space nuclear reactor power systems. The goal was to develop safe, compact, lightweight, and durable space reactor power systems to provide electrical power in the range of tens to hundreds of kilowatts. These space reactor power systems would make possible a broad class of emerging military and civil space missions in the early to mid-1990's and beyond. The DOE has primary responsibility for developing and ground-testing the nuclear subsystem. As part of this program, it was proposed that the SP-100 test reactor (maximum rating of 2.5 megawatt thermal [MWt]) be tested in the existing 309 Building. A ground test of a prototype was necessary to demonstrate the readiness of this major subsystem before proceeding with the flight system development and demonstration.

Following the test, it was anticipated that the reactor and associated hardware would be disposed of as LLW on the Hanford Site and that the enriched fuel material would be reprocessed and reused. Any TRU waste generated from reprocessing would be stored on the Hanford Site and ultimately sent to the Waste Isolation Pilot Plant (WIPP) in New Mexico. An alternative to reprocessing would be to dispose of the spent fuel at a DOE geologic repository constructed in accordance with the NWPA. Test facility systems external to the reactor and associated hardware would be put in a safe condition pending future use or ultimate decommissioning. Alternatives for $D \& D$ were still under review when the FONSI was written.

FONSI: $\quad$ Based on the analyses in the EA, the DOE issued a draft FONSI on December 15, 1988 (53 FR 50444), and distributed the EA and proposed FONSI for a 30-day public review period. The review period was later extended to 45 days. The DOE reviewed the comments and concluded that no new information was made available that would 
change the determination that the proposed action did not constitute a major federal action significantly affecting the quality of the human environment within the meaning of the NEPA. The final FONSI was issued September 27, 1989

(54 FR 39564).

The following actions were included in the FONSI:

- Following the test, it was anticipated that the reactor and associated hardware would be disposed of as LLW on the Hanford Site and that the enriched fuel material would be reprocessed and reused.

- Any TRU waste generated from reprocessing would be stored on the Hanford Site and sent to the WIPP in New Mexico when it becomes fully authorized as a disposal facility.

- The projected annual airborne release of argon-41 was 3.7 curies, and the projected release of tritium was 0.047 curies.

- The maximum whole body dose to the nearest resident from these releases was projected to be 0.00045 mrem. The 50 -year whole body dose commitment for the population within 80 kilometers was projected to be 0.0027 person-roentgen equivalent man (rem). The maximum offsite individual whole body dose was significantly smaller than the regulatory limit of $25 \mathrm{mrem}$ per year whole body dose and the annual dose from background radiation of $100 \mathrm{mrem}$. No employee was expected to receive a dose greater than 1 rem per year in everyday work areas or during maintenance.

- Reactor heat (up to $2.5 \mathrm{MWt}$ ) was to be dissipated to the atmosphere using forced-air dump heat exchangers. In addition, air conditioning would remove heat from support areas.

- The SP-100 Ground Engineering System test activities would have generated hazardous, radioactive, and mixed waste. The estimated annual radioactive solid waste volume would have been less than 28 cubic meters ( 990 cubic feet), or 7 percent of the total radioactive solid waste presently generated in the 300 Area.

- Minimal radioactive liquid waste would have been generated (less than 1,136 liters [300 gallons] each year), solidified, and disposed as solid LLW (included in the 28 cubic meters [ 990 cubic feet] discussed previously). No liquid waste was to be disposed in the soil. The LLW and solid mixed waste would have been buried in the 200 Areas Burial Grounds. The projected amounts of LLW and solid mixed waste would have been less than 1 percent of the total volume presently handled by the 200 Areas Burial Grounds.

- The 309 Building would have been modified to contain liquid metals and to minimize the effects of any liquid metal leakage.

- Commonly used hazardous materials, such as ethylene glycol, could be selected as the cooling medium in air conditioning systems. 
- When the FONSI was written, a specific mission was not identified for the SP-100 nuclear reactor power system. Therefore, specific flight system design requirements and mission parameters were not available. When a specific mission using an SP-100 nuclear power system would have been proposed, the potential environmental impacts of that mission would require appropriate NEPA documentation by either National Aeronautics and Space Administration or the U.S. Department of Defense as part of the flight approval process.

Current Status: The proposed SP -100 Ground Engineering System Test Site project was terminated in 1994.

DOE/EA-0358 Handling and Transportation of Isotopic Heat Sources

Prepared at the Hanford Site, Richland, Washington, draft.

The EA was abandoned following identification by Germany that they had no need for the source material.

DOE/EA-0370 Fast Flux Test Facility Power Addition, Hanford Site, Richland, Washington, draft.

The EA was abandoned when U.S. Department of Energy-Headquarters (DOE-HQ) questioned the future of the FFTF.

DOE/EA-0383 Hanford Environmental Compliance Project, Hanford Site, Richland, Washington, November 1991.

Background: $\quad$ This EA proposed covered 14 subprojects that were activities in the Hanford Environmental Compliance Program. The 14 subprojects covered four major types of activities:

- Groundwater monitoring

- Sample analysis capability

- Modifications to existing facilities to reduce environmental impacts

- Waste and effluent treatment, storage, and disposal.

FONSI: $\quad$ A FONSI was approved March 11, 1992.

The following actions were included in the FONSI:

- The subprojects scheduled for FYs 1989 and 1990 included Groundwater Monitoring Wells (W-017H), the B Plant Process Condensate Treatment Facility (W-007H), Waste Management Facilities Cathodic Protection (W-020H), the 300/400 Area Wastewater Facilities (V-791H), the Radioactive Mixed Waste (RMW) Storage Facility (W-016H), the Plutonium Finishing Plant (PFP) Liquid Low-Level Waste System Modification (B-680H), the PFP Liquid Effluent Treatment Facility (C-031H), B Plant Environmental Compliance Upgrades $(\mathrm{W}-010 \mathrm{H})$, and the Waste Sampling and Characterization Facility $(\mathrm{W}-011 \mathrm{H})$. 
- The subprojects scheduled for FY 1991 included B Plant Radiological and Containment Upgrades (W-024H), Environmental Hot Cell Expansion (W-041H), and the 242-A Evaporator/Plutonium-Uranium Extraction (PUREX) Process Treatment Facility (C-018H).

- The subprojects scheduled for FY 1992 included the 300 Area Treated Effluent Disposal Facility (L-045H) and the 200 Areas Treated Effluent Disposal Facility (W-049H).

Current Status: Construction activities are complete and facilities are operating.

DOE/EA-0411 Fuel Assembly Area,

Hanford Site, Richland, Washington, draft.

The EA was abandoned when DOE-HQ questioned the future of the FFTF.

DOE/EA-0429 Environmental and Molecular Sciences Laboratory

at the Hanford Site, Richland, Washington, May 1990.

Background: This EA proposed building a laboratory that would house basic and applied research components of the Environmental Science Research Center and the Molecular Science Research Center. The Environmental and Molecular Sciences Laboratory (EMSL) would provide, in a single location, the office and laboratory facilities necessary to: (1) conduct applied research directed toward environmental compliance and environmental remediation programs carried out by the DOE at the Hanford Site and at other DOE sites, and (2) conduct basic research at the molecular level in support of these and other DOE-sponsored applied-research programs.

The proposed EMSL would respond to a need for both basic and applied research required by the Research Development Demonstration Testing and Evaluation Program, and also would facilitate application of research to the Hanford Site, where as much as one-half of the DOE's hazardous and radioactive waste is stored or buried.

FONSI: $\quad$ The FONSI was approved September 17, 1992.

The following actions were included in the FONSI:

- The proposed laboratory is to be located at the south end of the Hanford Site 300 Area on a 8.093-hectare (20-acre) site near the Washington State University Tri-Cities campus.

- The EMSL would have approximately 18,580 square meters $(200,000$ square feet) of floor space and would contain laboratories, offices, model and machine shops, a graphics shop, conference rooms, a library, a kitchen, a lunchroom, and a lecture hall. Site development would require construction of utility extensions, driveways, parking lots, and landscaped areas.

- The building and site would be arranged to permit integration of laboratory and support activities with those of existing PNL facilities and other 300 Area facilities. 
- The EMSL staff would consist of approximately 200 scientists, technicians, and support personnel. An additional 60 visiting scientists are expected to be working at the facility at any given time.

- If necessary, ear protection devices would be used in accordance with the DOE contractor safety requirements during construction of the proposed facility.

- If necessary, work areas would be sprayed with water to reduce fugitive dust emissions produced during construction activities.

Current Status: The EMSL project broke ground in the fall of 1993. Because of archeological finds, the EMSL had to be relocated on the Hanford Site. Refer to DOE/EA-0959.

DOE/EA-0479

Collecting Crust Samples from Level Detectors in Tank SY-101

at the Hanford Site, Richland, Washington, November 1990.

Background: This EA proposed characterizing waste in 241-SY-101 tank. Characterization would have included removal of three level detectors and analyzing the waste encrusted on the detectors. The EA stated that no terrestrial, aquatic, or air quality impacts would result from the crust sampling and analysis. The EA also stated that no routine or potential accidental impacts of the proposed action would have had a significant impact on the quality of the human environment.

FONSI: $\quad$ The FONSI was approved November 16, 1990.

The following actions were included in the FONSI:

- The 241-SY-101 tank primary ventilation system was to be operational during sensor retrieval to prevent buildup of hydrogen in the tank dome space and to keep airborne radioactive emissions well below the DOE and contractor guidelines.

- Procedures and administrative controls were to be in place before detector retrieval and replacement, so that radiation exposure to onsite personnel was kept below the DOE orders and contractor guidelines ( 5 and 3 rem per year, respectively). These administrative controls would ensure adherence to the philosophy of maintaining exposures as low as reasonably achievable (ALARA).

- Radioactive material, radioactively contaminated equipment (including the retrieved detectors after removal of crust materials), and mixed waste were to be packaged and stored or disposed on the Hanford Site. None of this waste was expected to contribute significantly to the volume of waste generated annually at the Hanford Site.

Current Status: $\quad$ As of September 1995, the proposed activities were complete. 
DOE/EA-0495

Background:

FONSI:
Preparation for Crust Sampling of Tank 241-SY-101, Hanford Site, Richland, Washington, February 1991.

This EA proposed activities that support the anticipated core sampling of the 241-SY-101 tank. These activities included obtaining surface crust samples and installing dome space sampling and monitoring equipment (plus supporting electronics). Installation or replacement of monitoring equipment and sampling of tank contents were normally a routine activity. However, given the concerns with hydrogen accumulation in the 241-SY-101 tank and the potential for secondary crust reactions, a safety assessment and this EA were prepared to ensure that the proposed action was conducted in a safe and environmentally sound fashion.

The FONSI was approved February 15, 1991.

The following actions were included in the FONSI:

- An existing filtered ventilation system was to maintain negative pressure in the tank at all times to ensure that no radiological releases occurred.

- The crust samples were appropriately packaged and transported to Hanford Site laboratories.

- The samples were to be analyzed using approved procedures and analytical methods to determine exotherms, heat of reaction, and total organic carbon content. Thermogravimetric analysis (moisture content and water of hydration), analysis of anions (i.e., nitrate and nitrite), cations (i.e., sodium and aluminum), and other characteristics (i.e., specific gravity and other chemical species) were to be performed.

- The small quantities of waste generated from these analyses were to be properly packaged and stored or disposed in existing facilities on the Hanford Site.

- To maintain airborne radioactive emissions well below the DOE and contractor guidelines, the Tank 241-SY-101 primary ventilation system was to be operational during crust sampling and the installation and operation of the dome space gas sampling system.

- A backup exhaust system was to be available to provide containment if the primary ventilation system was lost.

- Appropriate administrative controls and monitoring procedures were to be in place before crust sampling and installation and operation of the dome space gas sampling system started. During laboratory analyses, these guidelines would keep hazardous chemical and radiation exposure to onsite personnel below the DOE orders and contractor guidelines (5 and 3 rem per year, respectively).

- Small quantities of hazardous materials (i.e., solvents and cleaning agents) generated were to be managed and disposed in accordance with applicable federal and state regulations. 
- Radioactive material, radioactively contaminated equipment, and mixed waste were to be appropriately packaged and stored or disposed in existing facilities on the Hanford Site.

- Assuming no respiratory protection, the operator doses were expected to be no more than $45 \mathrm{mrem}$.

Current Status: As of September 1995, crust sampling of the 241-SY-101 tank waste was complete.

DOE/EA-0511 Characterization of Tank 241-SY-101,

Hanford Site, Richland, Washington, May 1991.

Background: This EA proposed activities to support the characterization of the 241-SY-101 tank, which is located in the 200 West Area of the Hanford Site. Activities were proposed to occur only during the sampling 'windows' shortly after a tank venting (i.e., a major release of hydrogen to the dome space; when remaining hydrogen levels in the waste were the lowest). The proposed activities were the first five activities listed under the FONSI information.

Proposed actions would take place during the venting of 'Window C', which was expected to occur in May 1991. Similar activities (i.e., auger sampling of the crust core drilling) were proposed to be conducted during future sampling windows to obtain additional information. Depending on the initial sample results and conditions in the riser locations, DOE proposed that such sampling activities be conducted up to six times. For each proposed future sampling activity, DOE would reconsider whether the risks of those activities were covered by existing safety and NEPA documentation. If not, an additional NEPA review would be conducted, as appropriate.

Installation or replacement of monitoring equipment, and sampling of tank contents normally would be a routine activity. However, given the unreviewed safety issue of hydrogen accumulation in the 241-SY-101 tank, this EA also was prepared to ensure that the proposed action would be conducted in a safe and environmentally sound fashion.

FONSI:

The FONSI was approved May 10, 1991.

The following actions were included in the FONSI. The first five activities were the EA-proposed actions.

- Install two remote television cameras in the dome space of the 241-SY-101 tank.

- Complete penetrometer testing. As many as five penetrometer tests provided mechanical property data on the crust.

- Obtain as many as five samples of the crust using an auger sampler.

- Operate a microwave radar level gauge to provide additional monitoring of the tank crust surface level. 
- Obtain a full-depth sample of tank contents from the crust to the bottom of the tank using a core drill in the 'push mode' (i.e., no rotational motion would be applied to the drill). This core sample would provide the first waste material sample from beneath the crust. This waste would be analyzed and the data used to determine the validity of synthetic studies and current modeling of hydrogen generation.

- Waste samples were to be appropriately packaged and transported to Hanford Site laboratories. The samples were to be analyzed using approved procedures and analytical methods. Waste generated from analyses were to be properly packaged and stored or disposed in existing facilities on the Hanford Site.

- The primary ventilation system was to be operated during waste sampling and the installation and operation of the dome space gas sampling system to maintain radioactive emissions well below the DOE and contractor limits. A backup exhaust system was to be available to provide containment should the primary ventilation system be lost.

- Appropriate procedures and administrative controls would be in place to keep radiation exposure to workers below the DOE orders and contractor limits ( 5 and 3 rem per year, respectively) in keeping with the ALARA policy.

- Radiation and hazardous chemical levels at the waste site, and exposure of workers directly involved, would be monitored continuously during the proposed actions.

- Small quantities of generated hazardous materials would be managed and disposed in accordance with applicable federal and state regulations.

- Radioactive material, radioactively contaminated equipment, and mixed waste were appropriately packaged and stored or disposed in existing facilities on the Hanford Site.

- The potential consequences of this operation were considered small. Nevertheless, operating conditions were designed to further lessen the doses or likelihood of an accidental occurrence. Those operating conditions included factors such as continuous operation of the primary ventilation system, availability of the backup ventilation system, electrically bonding the riser cover and all equipment in and around the riser to the tank, and the use of spark-resistant tools.

Current Status: Evaluation and monitoring of the hydrogen buildup in 241-SY-101 tank has been completed.

\section{DOE/EA-0533 Vapor Space Sampling of Ferrocyanide Tanks,} Hanford Site, Richland, Washington, July 1991.

Background: $\quad$ This EA proposed sampling the vapor space of 24 Hanford Site SSTs that contain ferrocyanide-nitrate compounds to determine whether the SSTs contained flammable or toxic gases. The DOE needed to take action to help define the required controls to 
prevent or mitigate the potential for an accident during future, more intrusive sampling and monitoring of these tanks. Given the unreviewed safety questions (USQ) associated with the consequences of a potential ferrocyanide-nitrate reaction, a safety assessment and an EA were prepared to ensure that the proposed action was conducted in a safe and environmentally sound manner.

Standard operating procedures for sampling HLW tanks were revised to reflect the potential presence of flammable and toxic gases. The proposed action was conducted using nonsparking materials, spark-resistant tools, a portable containment shelter, and plastic ground cover. The proposed activities involved ferrocyanide-containing tanks located on land dedicated to DOE waste management.

FONSI:

Current Status:
The FONSI was approved August 2, 1991.

Based on anticipated findings, the DOE proposed to sample the vapor space of the 24 Hanford Site SSTs containing ferrocyanide compounds for flammable and toxic gases. This sampling would help define the controls to prevent or mitigate potential accidents during future, more intrusive sampling activities.

The sampling was to be performed in two parts. The first part would involve gas flammability and toxic vapor tests using, respectively, an industry-standard, intrinsically safe gas flammability meter and gas detector (Draeger ${ }^{1}$ ) tubes. The second part would involve cryogenic sampling using a cold trap followed by chemical analyses of the condensed gases in the analytical laboratory. It was anticipated that both types of sampling would be done sequentially on the same day. Appropriate respiratory protection was to be used by personnel during these activities, as required by standard operating procedures. Analyses obtained provided data on the presence of any flammable or toxic gases.

The sampling activities have been completed, with the analyses used in development of ongoing tank waste management activities.

105-KE and 105-KW Basins Fuel Encapsulation and Repackaging, 100-K Area, Hanford Site, Richland, Washington, June 1992.

Background: $\quad$ This EA proposed to provide containment of fuel assemblies with damaged cladding that exposed the metallic uranium to basin cooling water. This containment would be accomplished by encapsulating the fuel assemblies in stainless steel containers. The proposed action would also allow for a full range of options for final fuel disposition.

FONSI: $\quad$ The FONSI was approved June 23, 1992.

The proposed action was divided into two phases that were included in the FONSI:

- Phase I would consist of activities required to support the encapsulation and repackaging work.

\footnotetext{
'Drager is a trademark of Dragerwerk Akliengesellschaft.
} 
- Phase II would consist of encapsulating the fuel currently stored in the $105-\mathrm{KE}$ Basin, repackaging the fuel stored in the 105-KW Basin, and preparing and disposing of all empty canisters.

Current Status: All of the necessary permits are in place. The scope of the FONSI was abandoned and replaced by the Spent Nuclear Fuel Path Forward Document strategy (Integrated Process Strategy for K Basins Spent Nuclear Fuel, WHC-SD-SNF-SP-005). NEPA analysis for the disposition of the K Basins Spent Nuclear Fuel is DOE/EIS-0245 (Management of Spent Nuclear Fuel from the K-Basins).

DOE/EA-0538 Storage of Fast Flux Test Facility Unirradiated Fuel in the PFP Complex, Hanford Site, Richland, Washington, January 1992.

Background: $\quad$ This EA proposed relocating unirradiated fuel, stored for the FFTF, from the 308 Building to Room 192A at the PFP. This relocation reduced security costs and improved the safety of the fuel during a seismic event. The EA analyzed the impact of the radiation exposure on workers during loading, transportation, and storage.

FONSI: $\quad$ A FONSI was approved January 9, 1992.

The following actions were included in the FONSI:

- Remove unirradiated FFTF fuel from the 308 Building and store it inside its shipping containers in Room 192A, 234-5Z Building.

- Modify Room 192A to accommodate placement and routine retrieval of the fuel.

- If actual radiological measurements indicated additional shielding was needed after the fuel was in place, new shielding partitions would be installed.

- A gantry crane was to be assembled in Room 192A to assist in placing the shipping containers.

- Existing criticality detectors, security monitoring devices, and 120-volt electrical service were to be relocated to accommodate placement of the shipping containers.

- Temporary 440-volt electrical service was to be installed, if necessary, to operate the crane.

- All construction activities would occur within the 234-5Z Building.

- The fuel stored in the 308 Building was to be composed of fuel pins and fuel assemblies. Fuel pins were to be placed in shipping containers for shipment from the 308 Building to the 234-5Z Building. The fuel assemblies would be placed in radial reflector shipping containers.

- Both container types would be loaded onto trucks and transported approximately 43.5 kilometers (27 miles) to the $234-5 Z$ Building. Appropriate precautions would be taken to maintain the security of the fuel during transport. 
Current Status: The fuel was relocated and the 308 Building security area was removed May 15, 1992.

DOE/EA-0581 Upgrading of the Ventilation System at the 241-SY Tank Farm, Hanford Site, Richland, Washington, December 1991.

Background: $\quad$ This EA proposed upgrading the ventilation system at the 241-SY Tank Farm in the 200 West Area. Upgrades were necessary to provide safe ventilation to the 241-SY Tank Farm, which had a history of flammable gas buildup within the tanks (SY-101, SY-102, and SY-103).

FONSI: $\quad$ The FONSI was approved December 20, 1991.

The following actions were included in the FONSI:

- Immediate ventilation systems were to be upgraded. Upgrades included such activities as installing a 'tee' section to the ventilation duct, installing a portable exhaust fan at the 'tee' to provide a backup fan, and replacing the existing backup fan with a HEPA-filtered intake unit.

- Proposed future upgrade actions could include installing spark-resistant fans, installing permanent HEPA-filtered intake, and installing a 241-SY Tank Farm backup power supply.

Current Status: $\quad$ As of this publication, the proposed action has been completed.

DOE/EA-0582

Background:
Expedited Response Action for the 200 West Area Carbon Tetrachloride Plume at the Hanford Site, Richland, Washington, February 1992. (Note: This document is also known as an Engineering Evaluation/Cost Analysis - Environmental Assessment, DOE/RL-91-32)

On December 20, 1990, the U.S. Environmental Protection Agency (EPA) and Ecology requested that DOE assess contamination and evaluate alternatives for conducting an Expedited Response Action (ERA). The ERA would address concerns that carbon tetrachloride contamination, located in the unsaturated soil beneath certain disposal sites in the 200 West Area, would continue to migrate, affecting the groundwater. An ERA, also known as a removal action (defined in section 101(23) of the Comprehensive Environmental Response, Compensation, and Liability Act [CERCLA] of 1980, as amended), is intended to provide early remediation to reduce potential threats or prevent significantly-increased degradation that might occur if action were delayed until completion of the CERCLA remedial investigation/feasibility study and implementation of the final remedy selected in the CERCLA record of decision. The DOE prepared an EE/CA-EA to evaluate alternatives for conducting an ERA before completion of the CERCLA remedial investigation/feasibility study for the 200-AP-1 and 200-AP-2 operable units where the carbon tetrachloride disposal sites are located.

The proposed ERA involved the installation and operation of a soil vapor extraction system with recovery of contaminants onto granular activated carbon, and offsite 
activated carbon regeneration at a RCRA permitted facility. The proposed action was intended to reduce the quantity of carbon tetrachloride and other volatile contaminants in the soil column in the 200 West Area. The proposed action would reduce the potential for contaminant migration from the soil column to the groundwater, and reduce potential exposure to workers in the area pending final cleanup remedies for the 200-AP-1 and 200-AP-2 operable units. The proposed action would help make the final remedies to be selected for cleanup of these operable units achievable.

FONSI: $\quad$ The FONSI was approved February 20, 1992.

The proposed ERA actions involved the installation and operation of soil vapor extraction systems with recovery of contaminants onto granular activated carbon, and offsite activated carbon regeneration at a RCRA permitted facility. The proposed action is intended to reduce the quantity of carbon tetrachloride and other volatile contaminants in the soil column in the $200 \mathrm{West}$ Area. This would reduce the potential for contaminant migration from the soil column to the ground water, and reduce potential exposure to workers in the area pending final cleanup remedies for the 200-ZP-1 and 200-ZP-2 operable units. The proposed action would help make the final remedies to be selected for cleanup of these operable units achievable.

Current Status: Three vapor extraction remediation systems are operating continuously in the 200 West Area. The anticipated completion date is the year 2000.

DOE/EA-0596 Intrusive Sampling and Testing of Ferrocyanide Tanks, Hanford Site, Richland, Washington, January 1992.

Background: This EA proposed intrusive sampling, testing, and analysis to support the characterization of 24 SSTs that have been identified as having the potential for explosive mixtures of ferrocyanide and nitrate-nitrite.

The sampling would provide an understanding of the ferrocyanide-nitrate waste and its potentially reactive behavior, so that the tanks could be maintained in a safe condition with minimal risk of explosion. Strategies that could be developed and selected to implement safe interim stabilization and safe ultimate disposal options would be identified. A further objective of the sampling was to obtain data to assess the hazards associated with planned future rotary, full-depth drilling of a core sample in ferrocyanide tanks containing salt cake.

FONSI: $\quad$ The FONSI was approved February 11, 1992. The FONSI discussed the intrusive sampling and testing of the salt cake in 13 of the 24 tanks and sampling of the sludge in the remaining 11 tanks. Equipment to be used by this project would include an auger, a sludge weight, and push-mode core samplers. Testing of the salt cake would use a penetrometer that would provide mechanical property data.

Current Status: $\quad$ Sampling of the ferrocyanide tanks was completed in September 1996. This completed the resolution of the ferrocyanide watchlist tank safety issues. 
DOE/EA-0618

Background:

FONSI:

Current Status: The proposed action has been completed.

The FONSI was approved April 21, 1992. services.
Integrated Voice/Data Telecommunications System, Hanford Site, Richland, Washington, April 1992.

This EA proposed installing a new telecommunication system on the Hanford Site. The updated system would replace the existing telecommunication system and would integrate voice and data capabilities into a single digital network. This new system also would be more efficient and represent a cost savings for the DOE.

The following actions were included in the FONSI:

- Construction of buildings to be used for switching stations. These buildings would be constructed in the 300,100-N, 200 East, 200 West, and 400 Areas on the Hanford Site, and the 700 and 3000 Areas within the City of Richland.

- New communication cables (principal fiber optic cables) would be installed underground between the switching stations both onsite and offsite.

- Normal upkeep of the buildings, including repair and replacement of telecommunication lines, maintenance of buildings and utilities, and custodial

Construction of Temporary Mobile Office Complex, 200 West Area, Hanford Site, Richland, Washington, June 1992.

Background: This EA proposed construction and operation of a temporary mobile office and change room complex near the 272-WA Building in the 200 West Area. The temporary mobile office complex would consist of two 16-module office units, each consisting of approximately 1,362 square meters ( 14,800 square feet) of space and a separate four module change unit of about 340 square meters ( 3,700 square feet) containing change areas for personnel. The mobile office complex would accommodate 180 office personnel and would provide showers and changing areas for up to 50 operating personnel.

Alternatives: The alternatives in this EA were as follows.

- The no-action alternative was to not build the temporary mobile office complex.

- Five alternative sites were considered as possible locations for the temporary mobile office complex. Potential environmental impacts would have been essentially the same for all sites considered, and no alternative site had a higher overall rating than the site in the proposed action; therefore, the five alternative sites were dismissed from further consideration in the EA.

A FONSI was approved June 12, 1992.

The following actions were included in the FONSI: 
- Perform the work described in the proposed action.

- The work would be performed in a previously disturbed area.

- If deemed necessary, because of noise from construction work, ear protection devices would be used in accordance with the DOE contractor safety requirements.

- If deemed necessary, because of increased dust from construction, work areas would be sprayed with water to further reduce fugitive dust emissions.

- No operation at the mobile office complex would involve radioactive or hazardous materials.

- The sanitary sewer system would consist of a conventional septic tank and drain field with the effluent discharged to the soil. The sanitary waste system would be designed and constructed to operate in conformance with current Washington State and Benton-Franklin County regulations.

- An archeological study completed in the 200 West Area in 1990 revealed that the historic White Bluffs Road passes within several hundred feet of the proposed mobile office complex site (Chatters and Cadoret 1990). A buffer zone, which measured 18.3 meters ( $60 \mathrm{feet}$ ) in width, has been established on either side of the historic road, with no construction permitted.

- An archaeological zone, 100 meters (328 feet) wide, was established on either side of the historic road. The proposed action does not fall within this archaeological zone. However, a cultural resources review would be completed before the start of construction if concerns about potential impacts to the archaeological zone arise as a result of the proposed action. Any requirements stipulated by the cultural resources review would be met.

Current Status: The construction of the temporary mobile office complex has been completed and the complex is occupied.

DOE/EA-0787 Shipment of Low Enriched Uranium Billets to the United Kingdom from the Hanford Site, Richland, Washington, August 1992.

Background: $\quad$ This EA proposed shipping approximately 2,500 low-enriched uranium billets to the United Kingdom. These billets were fabricated for the manufacture of fuel by the Hanford Site N Reactor, but are now surplus because defense reactor operations have been discontinued at the Hanford Site. The EA specifically analyzed the loading and transportation of these billets, which would be divided into four shipments.

FONSI: $\quad$ The FONSI was approved August 27, 1992.

The FONSI included the following actions:

- The billets were to be loaded into closed-type International Standards Organization containers. 
- The containers, with the billets enclosed, would be transported by truck to the Port of Seattle, approximately 344 kilometers ( 215 miles).

- After delivery to the port, the containers would be loaded aboard an oceangoing cargo vessel and transported to the United Kingdom.

Current Status: In February 1993, the last of the four shipments reached the United Kingdom.

\section{DOE/EA-0802}

Background:
Tank 241-SY-101 Equipment Installation and Operation to Enhance Tank Safety, Hanford Site, Richland, Washington, August 1992.

This EA proposed enhancing the 241-SY-101 tank safety. The DOE is responsible for the management and storage of HLW accumulated as a result of processing defense reactor irradiated fuels for plutonium recovery on the Hanford Site. The 241-SY-101 tank has been found to release quantities of hydrogen gas at concentrations above the lower flammability limits (LFL).

The proposed action was to install and operate various instruments and equipment designed to mitigate the potential for an accident during continued waste storage in the 24l-SY-101 tank. This EA also aliows for the accumulation of additional data on the chemical and physical properties of the waste in this tank.

The proposed action would include installing and operating the following:

- A multifunctional instrument tree to provide temperature and gas data

- A standard hydrogen monitoring system

- A fourier transform infrared spectrometer and a gas chromatograph to analyze gas constituents

- A velocity, density, and temperature tree to measure pressure as it relates to density and temperature

- A permanent inlet filter.

The EA also allowed for the installation of a plug gauge, removal of existing air lances, and various preparatory activities.

The FONSI was approved August 13, 1992.

The FONSI included the following actions:

- Removal of four existing air lances

- Installation and operation of permanent inlet filters for the 241-SY Tank Farm 
- Installation and operation in the 241-SY-101 tank of a multifunctional instrument tree, standard hydrogen monitoring system, a fourier transform infrared system, gas chromatographs, velocity-density-temperature probes, and a riser plug gauge

- The construction and installation of concrete pads to support the instrumentation and underground conduit for the power and instrumentation lines.

Current Status: $\quad$ As of July 1993, the proposed activities have been completed.

\section{DOE/EA-0803 Proposed Pump Mixing Operations to Mitigate Episodic Gas Releases in Tank 241-SY-101, Hanford Site, Richland, Washington, September 1992.}

Background: This EA proposed defining controls required to mitigate the potential for an accident during continued waste storage in the 241-SY-101 tank. The intent of installing and operating a mixer pump was to test the possibility of mixing the waste that causes trapped gas (hydrogen) bubbles to be released on a continuous basis. Theoretically, releasing gas in this manner would eliminate the episodic gas releases, which periodically caused the gas weight percent to exceed the 25 percent LFL for the tank.

The proposed action consisted of the following activities:

- Remove a slurry distributor from a 106.68-centimeter (42-inch) riser in the tank

- Install, operate, and remove a mixer pump.

FONSI: $\quad$ The FONSI was prepared by the Los Alamos National Laboratory and submitted (by them) to DOE-HQ. The FONSI included the removal of the existing slurry distributor from the 241-SY-101 tank and the installation, operation, and removal of a submersible mixer pump in the tank riser the sluicer was removed from.

Current Status: $\quad$ As of September 1995, the pump was fabricated, installed, tested, and is operational.

DOE/EA-0809 Thermocouple Tree System Installation and Operation in Non-Leaking Ferrocyanide Tanks, Hanford Site, Richland, Washington, September 1992.

Background: This EA proposed the installation and operation of a thermocouple tree system in non-leaking ferrocyanide tanks. The DOE records indicate that 24 high-level waste storage SSTs on the Hanford Site may each contain enough ferrocyanide, if heated sufficiently, to initiate a self-sustaining chemical reaction with the substantial quantity of nitrate-nitrite salts and/or saturated nitrate-nitrite solutions that exist in these tanks. A safety concern associated with the current in-tank temperature data focuses on the potential for localized areas in the waste to develop above-average temperatures (hot spots) as a result of radioactive decay. This could lead to a thermal runaway reaction or an explosion and release of radioactive material from the tanks. Although the proposed action to install one thermocouple tree (TCT) system in each of the 11 nonleaking ferrocyanide SSTs at the Hanford Site would be inadequate to ensure that all hot spots have been located; the additional temperature data provided substantially would improve the DOE's understanding of the ferrocyanide tanks. 
The proposed action is to install and operate one TCT system in each of the 11 nonleaking SSTs containing ferrocyanide compounds at the Hanford Site.

FONSI:

The FONSI was approved September 18, 1992.

The FONSI included the following actions:

- Gas sampling of each tank's vapor space would be conducted to ensure that no flammable gases greater than 20 percent of the respective LFLs were present. If flammable gas above these levels were detected, the TCT systems would not be installed in the tanks until additional evaluations were performed to ensure that flammable gas concentrations were at safe levels.

- The TCT systems would be lowered through a riser in each of the 11 tanks by a hydraulic crane, and up to 5,678 liters (1,500 gallons) of water per tank would be used to jet the TCT systems through the salt cake layer.

- The TCT systems would remain in the tanks indefinitely until future DOE decisions on tank waste remediation are made.

- Signals generated from individual thermocouple elements on the TCT systems would be transmitted by existing or newly installed cables, and the temperature data would be monitored manually or with existing or newly installed data acquisition systems at other Hanford Site locations.

Current Status: As of September 1995, all the thermocouple probes were installed and are operational, which completes the proposed action.

DOE/EA-0829 Final RI/FS - EA Report for 1100-EM-1 Operable Unit, draft, December 1992.

This is not an approved NEPA document. This draft report was prepared in December 1992 under DOE/RL-92-67 (refer to Section 7.0).

DOE/EA-0876

Construction and Operation of Particle Accelerator Bio-Physical Laboratory, draft.

The project has been suspended.

DOE/EA-0881

Tank 241-C-103 Organic Vapor and Liquid Characterization and Supporting Activities, Hanford Site, Richland, Washington, August 1993.

Background: $\quad$ This EA proposed to sample the 241-C-103 tank organic vapor and liquid waste. Because of the potential for ignition of the vapors from the floating organic layer in the 241-C-103 tank, the DOE has declared the tank an Unreviewed Safety Question (USQ). Operations at this tank were curtailed because of this USQ, which had to be resolved before normal waste storage operations and routine surveillance can continue. This EA analyzed the characterization of the vapor space and the organic and aqueous waste layers. This characterization is needed to determine if a flammable condition within the tank is credible. 
FONSI:

Current Status:
The FONSI was approved August 10, 1993.

The FONSI included sampling of the vapor space and organic layer in the tank and measuring the thickness of the organic layer. The FONSI also addressed actions to support the sampling task and to ensure safe operating conditions in the tank, including: routine tank vapor space surveillance activities; instrument calibration; preventive maintenance; installation and removal of small-scale components; breather filter testing; installation and removal of equipment for above ground facilities; installation and operation of a portable exhauster; small volume waste additions to the tank; and other activities that would not alter vapor space flammability.

The liquid sampling of the organic layer was completed December 15, 1993. Routine surveillance of the tank continues.

DOE/EA-0904 Access Road From State Route 240 to the 200 West Area, Hanford Site, Richland, Washington, February 1994.

Background: This EA proposed to construct an access road from State Route 240 to the 200 West Area on the Hanford Site. The DOE determined that dangerous traffic conditions exist with the main highway that connects the city of Richland and the 200 Areas. Traffic studies indicate that there is a high probability of a fatal accident occurring in the next several years. A temporary solution to this problem would be to construct an access road connecting State Route 240 to the 200 West Area. This would reduce the vehicular traffic on the main highway to acceptable levels until future, permanent solutions are proposed and implemented.

FONSI: $\quad$ The FONSI was approved March 10, 1994.

The FONSI included the construction of a 3.5-kilometer (2.2-mile) two-lane road connecting State Route 240 to the 200 West Area. This project would include acceleration and deceleration lanes on State Route 240, a truck turnaround and guardhouse on the new road, and modifications to the security fencing in the area. Habitat enhancement activities, which would likely include revegetation of shrub-steppe habitat at other disturbed locations of the Hanford Site, would be adopted to offset the removal of this habitat.

Current Status: Construction activities were completed and the access road is in use.

DOE/EA-0915 Waste Tank Safety Program, Hanford Site, Richland, Washington, February 1994.

Background: This EA proposed a programmatic NEPA document to cover waste tank safety activities in the tank farms. The DOE determined to actively resolve safety issues associated with the underground storage tanks on the Hanford Site. Specific safety issues associated with these tanks included the following:

- Flammable gas generation and episodic release

- Ferrocyanide-containing waste 
- Floating organic solvent layer in the 241-C-103 tank

- Nuclear criticality

- Toxic vapors

- Infrastructure upgrades

- Interim stabilization of SSTs.

In addition, knowledge of the waste tank contents was incomplete and additional characterization was called for in the Tri-Party Agreement.

FONSI: $\quad$ The FONSI was approved February 25, 1994.

The proposed actions in the FONSI include the following:

- Address safety concerns with the flammable gas generation tanks; the proposed action would install, operate, and remove in-tank monitoring equipment. Other actions needed include waste characterization and ventilation system monitoring and minor modifications.

- The same general activities described for the flammable gas generation tanks also apply to the ferrocyanide-containing tanks. Closure of the ferrocyanide USQ has been accomplished by the DOE.

- Closure of the criticality USQ has been accomplished by the DOE.

- Resolve the unreviewed safety question with the floating organic solvent layer in the 241-C-103 tank, the proposed action would allow for organic characterization and it subsequent removal.

- Include sampling and characterization of vapors from suspect tanks. Ventilation system enhancements and minor modifications to mitigate noxious vapors and toxic vapor emissions also would be allowed.

- Include modernization of facilities, improvements in plant instrumentation and data collection systems, and minor modifications to ventilation systems infrastructure upgrades, as required.

- Remove the pumpable liquid in 43 SSTs to minimize the impact from potential future tank leaks to support interim stabilization of the tanks.

Current Status: The FONSI was approved February 1994. Various activities (e.g., camera and liquid-level monitor installation) have been done under this NEPA coverage in the Tank Farms. This is a programmatic Tank Farm EA that provides ongoing NEPA coverage for Tank Farm activities.

\footnotetext{
DOE/EA-0921 Proposed Relocation and Resumption of DOE Radon Research Program in the 300 Area,

October 1994.
}

Background: This EA proposed the relocation and resumption of a DOE radon research program, relocating the DOE-owned radon generators from Battelle-owned Life Sciences 
Laboratory II (LSL-II), Richland North Area, to DOE-owned Life Sciences Laboratory I (LSL-I, also known as the 331 Building), 300 Area, Hanford Site.

The DOE has identified a need to continue to provide a controlled source of radon-222 for use in physical and biological research. The radon generators were located in the Life Sciences Laboratory II, which is privately owned by Battelle Memorial Institute. The radon generating equipment is owned by the PNL, operated by Battelle, Pacific Northwest Division. The need for relocating the radon generators to the LSL-I facility in the 300 Area was to preclude occurrence of an accident, however unlikely, where a spill of radium-chloride solutions would enter the LSL-II floor drains and contaminate the City of Richland sewer system. Although such an accident would have negligible health impacts, it could result in unnecessary public concern and high clean-up costs.

Radon generators at PNL are a core resource of the overall DOE Radon Research Program and were administratively controlled within the "Radon Hazards in Homes" project. This project primarily focused on radon exposures of animals and addressed the major biologic effects and factors that influence risks of indoor radon exposures.

FONSI:

The FONSI was approved on October 19, 1994.

The proposed action addressed in the FONSI is to relocate DOE-owned radon generators from Battelle-owned LSL-II, to DOE-owned LSL-I in the 300 Area, by:

- Remodel four presently unused rooms in LSL-I

- Fabrication and installation of a radon progeny hold-up ventilation exhaust system

- Installation of exposure chambers

- Removal of the radon-222 generators from LSL-II

- Transportation of the generators to LSL-I

- Installation of the generators and connection to the hold-up system

- Decontamination of present LSL-II radon exposure facilities if necessary

- Resumption of physical and biological research in LSL-I.

Current Status: The modifications to the 331 Building have been completed. The radon source was relocated to the 331 Building. However, the DOE has put a hold on the remainder of the proposed work subsequent to relocating the radon source.

DOE/EA-0933

Tank 241-C-106 Past-Practice Sluicing Waste Retrieval, Hanford Site, Richland, Washington, February 1995.

Background: This EA proposed to sluice the high-heat waste from the 241-C-106 tank to a DST through one of two proposed double-encased (pipe-in-pipe design), bermed lines. 
The DOE has identified a need to take this action to eliminate safety concerns with the storage of high heat waste in the 241-C-106 tank, and demonstrate a tank waste retrieval technology. The system would be a closed loop, continuous sluicing process. The scope of the project is to remove 75 percent, at a minimum, of the high heat waste.

In November 1990, Public Law 101-510, Section 3137, "Safety Measures for Waste Tanks at Hanford Nuclear Reservation" was enacted, which authorized that DOE develop plans for response to safety issues associated with the waste storage tanks at the Hanford Site. The progress of implementation for these plans will be reported to the U.S. Congress. In the resulting "Status Report on Resolution of Waste Tank Safety Issues at the Hanford Site," the 241-C-106 tank is identified as a high heat tank and one of the "Priority 1 " safety issues at the Hanford Site.

Past practice of sluicing underground storage tanks (UST) involves introducing a high-volume, low-pressure stream of liquid to mobilize UST sludge waste before pumping the tank contents.

The 241-C-106 tank is located in the 200 East Area. It has a useable waste depth of approximately 4.8 meters ( 15.7 feet) at the sidewall and is a SST. The waste consists of 746,000 liters (197,073 gallons) of sludge, which is stratified into two layers. The top layer consists of 655,000 liters (173,033 gallons) of sludge, containing a sufficient amount of strontium to be considered high-heat waste that generates approximately $32 \mathrm{~kW}$ of heat. The bottom layer consists of 91,000 liters (24,040 gallons) of low-heat producing hardened material.

FONSI: $\quad$ The FONSI was approved February 17, 1995.

The selected action in the FONSI is as follows.

- Waste retrieval operation will involve introducing a high volume, low pressure stream of liquid through sluicing nozzles to mobilize the sludge waste and prepare the waste for pumping.

- One sluicing nozzle will operate in the existing sluice pit, while the other will operate in the existing pump pit, if needed. Only one sluicer will operate at any one time.

- A new submersible pump will be installed in the 241-C-106 tank to transfer the slurry to the 241-AY-102 tank.

- Remove some of the existing equipment in the pump and sluice pits and stored on the Hanford Site for subsequent treatment and disposal. Clean and apply paint or fiber coating to the inside surfaces of the pits, as appropriate.

- Supernatant will be pumped from the 241-AY-102 tank to allow for sufficient space for the waste transfer from the 241-C-106 tank.

- Supernatant from the 241-AY-101 tank, or other appropriate sluicing fluid, will be pumped to the 241-AY-102 tank to be used as the initial sluicing agent. 
- A new HEPA filtration system will be added to the 241-C-106 tank to minimize releases to the atmosphere. Also, a recirculating air system will be installed to control the temperature and humidity of the vapor space during sluicing.

- Additional instrumentation will be provided in both tanks and in the transfer lines between the tanks.

- A double-wide trailer outside of the 241-C Tank Farm will serve to house centralized monitoring and control instrumentation.

- Support services in the form of raw water, sanitary water, electrical power, telecommunications, and hoisting hardware will be provided.

Current Status: The sluicing system design is complete; system construction, installation, testing, and operational acceptance is being implemented.

DOE/EA-0942 Return of Isotope Capsules to the Waste Encapsulation and Storage Facility, Hanford Site, Richland, Washington, May 1994.

Background: This EA proposed to return isotope capsules to the Waste Encapsulation and Storage Facility (WESF) on the Hanford Site. Historically, DOE has shipped radioactive isotope capsules, containing cesium-137 and strontium-90, to other DOE-controlled sites, as well as commercial facilities. Because of uncertainty regarding the failure of one capsule in a commercial facility (Decator, Georgia), DOE has determined that it needs to return leased capsules from the IOTECH, Incorporated (Northglenn, Colorado); Pacific Northwest Laboratory (Richland, Washington); and Applied Radiant Energy Company (Lynchburg, Virginia), to the WESF.

FONSI: $\quad$ The FONSI was approved May 25, 1994.

The selected action described in the FONSI required remote physical testing of the capsules at their present site to ensure capsule integrity and appropriate handling. The capsules would be packaged according to DOE and NRC guidelines, secured to truck trailers, and transported (according to DOE and DOT procedures) to WESF.

Current Status: All capsules have been returned to the Hanford Site.

DOE/EA-0944

222-S Radioactive Liquid Waste Line Replacement and 219-S Secondary

Containment Upgrade, Hanford Site, Richland, Washington. January 1995

Background: $\quad$ This EA proposed to replace the 222-S radioactive liquid waste line and the 219-S secondary containment system that transfers liquid waste to the 24l-SY Tank Farm. The DOE identified a need to take this action to:

- Bring the 222-S Laboratory (222-S) Complex radioactive liquid waste lines into compliance with existing secondary containment and leak detection requirements specified in Washington Administrative Code (WAC) 173-303 
- Reduce potential risks to the environment and to worker safety

- Reduce the risk of laboratory shutdown due to failure of the waste system

- Upgrade the 219-S Waste Handling Facility.

The 222-S was built in 1951 to support the 202-S Reduction-Oxidation (REDOX) Plant and the 200 Areas tank farms. The laboratory now is used to perform analytical services on radioactive samples in support of the Tank Waste Remediation System (TWRS) Program and Hanford Site environmental restoration programs. Activities conducted at 222-S include decontamination of analytical processing and support equipment and disposal of non-archived radioactive samples. These activities generated low-level liquid mixed waste.

The waste historically was transferred from 219-S through a buried pipeline to the 241-SY Tank Farm in the 200 West Area for storage. However, the current practice is to transfer waste via tanker truck from 219-S to a tank farm in the 200 East Area because of concerns regarding the integrity of the existing line between 219-S and the 241-SY Tank Farm. Ecology is now allowing this to be done on an interim basis under a Part A dangerous waste permit.

The 222-S is expected to remain in use for at least the next 30 years to serve the Hanford Site environmental cleanup mission. Failure of the drain and transfer piping systems or any of the 219-S tanks would result in shutdown of the laboratory complex.

FONSI: $\quad$ The FONSI was approved January 24, 1995.

The FONSI included the following actions:

- Replace drain piping in the 222-S service tunnels, the piping in the underground concrete encased pipe trenches between the 222-S service tunnels and 219-S, and the waste transfer lines between $219-\mathrm{S}$ and the receiving tank farm

- Upgrade 219-S to meet secondary containment, leak detection, and seismic design requirements

- Repair and recoat the cell compartments with a chemically resistant sealer and lined with stainless steel to provide secondary containment and leak detection.

Current Status: The proposed action was performed in two phases. The first phase was to install a new transfer line from the lab to the tank farms. This work was completed in December 1995. The second phase was to renovate the lab piping and cell interiors and is complete. 
DOE/EA-0959 Resiting, Construction, and Operation of the Environmental and Molecular Sciences Laboratory at the Hanford Site, Richland, Washington, July 1994.

Background: The EA proposed to re-site, construct, and operate the Environmental and Molecular Sciences Laboratory (EMSL). The DOE has identified a need for additional laboratory services on the Hanford Site to provide, at one location, the combined office and laboratory facilities necessary to conduct research directed toward environmental restoration programs carried out on the Hanford Site and other DOE sites. In response, the EA analyzed the construction and operation of the EMSL to be located north of the city of Richland. An EA (DOE/EA-0429) originally was written and approved in September 1992 to construct the laboratory on a site closer to the Columbia River. On September 17, 1992, DOE issued a FONSI for the construction and operation of the EMSL on a site overlooking the Columbia River at the south end of the 300 Area. On the second day of construction, April 12, 1994, construction crews uncovered human remains thought to be those of Native Americans. The DOE immediately halted construction and proposed, consistent with the wishes of local Indian tribes and with the spirit of the Native American Graves Protection and Repatriation Act and the American Indian Religious Freedom Act, to relocate the site. This EA, therefore represents the estimated environmental impacts of the construction and operation of the EMSL on a new site.

FONSI: $\quad$ The FONSI was approved July 7, 1994.

The FONSI addressed construction and operation of a 18,500-square meter (200,000-square foot) facility, which would house laboratories, offices, research support shops, a lecture hall, conference rooms, a library, and other miscellaneous functions. The FONSI also allows for infrastructure upgrades in the area to support the operation of the laboratory.

Current Status: Construction is complete and the laboratory is operating.

DOE/EA-0978 Sludge Stabilization at the Plutonium Finishing Plant, Hanford Site, Richland, Washington, October 1994.

Background: This EA proposed to stabilize the sludges in the gloveboxes as an interim action pending completion of the PFP EIS analysis and ROD concerning the proposed cleanout of the PFP and stabilization of the remaining materials within the PFP. This is a result of a need that DOE has identified to reduce worker exposure to radiation at PFP.

The PFP workers account for nearly half of all Hanford Site radiation worker exposure. One of the largest sources of worker exposure that can be decreased is the constant need for proximity of workers to unshielded gloveboxes containing sludges to monitor the conditions of sludge containers, to inventory material, and to perform routine housekeeping and preventative maintenance operations.

FONSI: $\quad$ The FONSI was approved October 19, 1994.

The action described in the FONSI is as follows: 
- Stabilize the chemically reactive, plutonium-bearing sludges within the process gloveboxes in the PFP Plant, and store the stabilized sludges in shielded storage vaults within PFP

- Stabilize the sludges by heating them to a range of approximately $500^{\circ}$ to $1,000^{\circ} \mathrm{C}$ and convert them to plutonium oxide. The other chemicals not driven off by the heat would remain as stable impurities in the resulting solid. The solid plutonium oxide would be stored in sealed containers in the vaults at PFP. There are approximately 300 containers of reactive scrap sludges that require stabilization. Sludge stabilization is expected to take about 14 months.

Current Status: The project is ongoing. Work stoppages at PFP resulted in delays of all activities at the facility; however, this action is expected to be completed in FY 2001.

\section{DOE/EA-0980 300 Area Process Sewer Piping Upgrade and 300 Area Treated Effluent Disposal Facility Discharge to the City of Richland Sewage System, Hanford Site, Richland, Washington, May 1995.}

Background: This EA proposed to upgrade the 300 Area process sewer piping system and connect the treated effluent disposal facility discharge to the city of Richland sewage system. This addressed the DOE's need to:

- Take action to reduce, or where appropriate, eliminate untreated liquid effluents discharged to the soil in the 300 Area

- Reduce anticipated operating costs at the new 300 Area Treated Effluent Disposal Facility (TEDF), which became operational December 1994

- Improve the questionable integrity of the old piping in the existing 300 Area process sewer system (e.g., effluents potentially could be entering the soil from leaking pipes).

The 300 Area process sewer system discharges effluents to the TEDF collection sump and lift station. The construction and operations of the TEDF was addressed in a previously approved environmental assessment (Hanford Environmental Compliance Project, DOE/EA-0383). The process waste liquid effluent was well below the DOE requirements for radiological secondary containment, and is not considered a RCRA hazardous waste or a State of Washington Hazardous Waste Management Act dangerous waste.

FONSI: $\quad$ The FONSI was issued May 25, 1995.

The action described in the FONSI is as follows:

- Upgrade the existing 300 Area process sewer system through the construction and operation of a new collection system

- Construct and operate a combined gravity, vacuum, and pressurized collection system from the TEDF. Design the system for extra capacity of about 25 percent 
for connection of additional buildings as necessary and for future growth. After processing the waste, either pump the effluent to the tie line for transfer to the city of Richland system or directly to the Columbia River. This action will provide two options for discharge of the 300 Area process effluent

- Connect the new collection system to about 36 of the existing buildings that still require process sewer drains

- Reconstruct all asphalt or concrete paving in roads, walkways, and parking lots subsequent to excavating for collection stations and trenching for the new pipe

- Incorporate existing sewer lines in the new system rather than being replaced if found to be in good condition and uncontaminated

- Provide for the construction of a buried discharge line from the TEDF to Lift Station Number One of the new 300 Area sanitary sewer line in the event a decision is made to connect the TEDF to the city of Richland sewage system. This decision is contingent on an agreement with the city of Richland.

Current Status: The actions were completed in May 1996.

\section{DOE/EA-0981 Solid Waste Retrieval Complex, Enhanced Radioactive and Mixed Waste Storage} Facility, Infrastructure Upgrades, and Central Waste Support Complex

Background: This EA proposes to construct and operate the following:

- Solid Waste Retrieval Complex

- Enhanced Radioactive Mixed Waste Storage Facility

- Central Waste Support Complex

- Associated infrastructure upgrades.

These facilities would be located in the 200 West Area to support the Solid Waste Operations Complex operation.

This proposed action would address DOE's need to:

- Retrieve TRU waste

- Provide storage capacity for retrieved and newly generated TRU

- Upgrade the infrastructure network in the 200 West Area to enhance operational efficiencies and reduce the cost of operating the existing Solid Waste Operations Complex.

FONSI: $\quad$ The FONSI was approved on September 28, 1995.

The selected action in the FONSI was to construct and operate the Retrieval Complex, the Enhanced Radioactive Mixed Waste Storage Facility (Storage Facility), the Central Waste Support Complex (CWSC), and associated infrastructure upgrades (i.e., utilities, roads) in the 200 West Area to support the Solid Waste Operations 
Complex (SWOC). In addition, the proposed action includes a mitigation strategy which has been developed to address lost priority shrub-steppe habitat. The estimated cost of the action is $\$ 66$ million.

Other selected FONSI actions include:

- Initiate the retrieval activities from Trench 4C-T04 in the 200 West Area including the construction of support facilities necessary to carry out the retrieval operations

- The retrieval of post-1970 solid waste suspected of containing TRU radionuclides and the construction, operation, and maintenance of a complex of facilities to be used for the retrieval

- Provide a RCRA permitted storage facility for retrieved TRU and newly generated TRU, mixed, and GTC3 waste awaiting processing in the WRAP facility and for processed waste awaiting shipment to the permanent disposal site

- Two pre-engineered metal solid waste management support buildings

- Clear shrub-steppe habitat to construct new facilities

- Compensate for priority habitat loss in accordance with the Sitewide Mitigation Strategy when it is approved.

Current Status: Funding constraints have limited the actions that were selected and documented in the FONSI. Pre-engineered structures have been installed in the CWC and some infrastructure upgrades have been completed. Future activities will be contingent on budget and priorities.

DOE/EA-0982

Special Case Material, Construction and Operation of a Storage Unit, draft.

Background: This EA proposes to construct and operate a Special Case Material storage unit. The proposed high-activity remote-handled $(\mathrm{RH})$ waste storage facility would be a storage system consisting of such components as:

- Solid waste containers

- Shipping casks

- Transfer system

- Storage modules similar to that used by the commercial nuciear power industry.

The DOE has identified a need to centralize storage of $\mathrm{RH}$ radioactive waste. Also, $\mathrm{RH}$ waste needs to be relocated from the 300 Area Radiochemical Engineering Cells (REC) because the 324 Building B-Cell's HEPA filtration system could fail in the event of a seismic event. This could create a radiological release above the DOE offsite limit of 100 millirem effective dose equivalent to the general public.

The proposed action would provide a centralized $\mathrm{RH}$ storage facility with monitoring and retrievability capabilities in the 200 West Area. The action also would include 
HNF-SP-0903, Rev. 7

FONSI: $\quad$ The EA has not been finalized.

Current Status: This EA was suspended in the Fall of 1995 because of lack of funds but has since been reactivated. A DOE-RL EA Review Panel met on March 12, 1996, to consider whether the draft EA is ready for review by the tribes and state. The Panel questioned whether the proposed action was still needed in view of other decisions such as the Canister Storage Building. The EA has been placed on hold.

\section{DOE/EA-0983 Inert/Demolition Waste Landfill (Pit 9),}

Hanford Site, Richland, Washington, May 1995.

Background: $\quad$ This EA proposed to construct a waste landfill (Pit 9) to accumulate inert and demolition waste for the Hanford Site. The DOE has identified a need for a convenient and economical disposal capacity of these types of waste to support the demolition activities planned for the southern areas of the Hanford Site.

The current demolition waste landfill, Pit 10, located approximately 25 meters ( 8.2 feet) west of Route 4 S, reached full capacity in 1995 . The projected demolition activities on the Hanford Site will continue for up to 20 years. As a result, a replacement demolition landfill is required in the near term. Therefore, DOE proposed to use an existing alluvial gravel pit, Pit 9, as a new inert and demolition waste landfill for the Hanford Site. Pit 9 is located approximately 3 kilometers north of the 300 Area, in the 600 Area of the Hanford Site. It would be converted to use as an inert/demolition waste landfill by installing a lockable access gate at the entrance, and a fenced barrier around the entire landfill area and appropriately posted. No other physical alterations in the Pit 9 area would be necessary.

This action would support the disposal phase of various infrastructure demolition projects in the southern areas of the Hanford Site. These demolition projects would produce waste consisting of concrete, brick, incidental wood, used asphalt, and steel. Because of the large size of Pit 9, current disposal projections estimate that the pit would be available for the noted types of waste for 20 years.

FONSI: $\quad$ The FONSI was approved May 15, 1995.

The action described in the FONSI is as follows:

An existing alluvial gravel pit, Pit 9 would be used, as a new inert and demolition waste landfill. It would support the disposal of various infrastructure demolition projects in the southern areas of the Hanford Site.

Controls restricting the disposal of inert and demolition waste types would be strictly enforced. Workers at the demolition sites would segregate the various waste types according to DOE contractor procedures administrative controls to ensure all hazardous, dangerous, radioactive, asbestos, and liquid waste are separated and not included in the inert and demolition waste to be placed into dump trucks bound for the proposed inert/demolition waste landfill. 
When Pit 9 reaches its full capacity, or is no longer needed, the pit would be covered with a minimum of 0.3 meter ( 1 foot) of soil, any voids would be filled to maintain an aesthetic appearance, and the site revegetated with native species derived from the Hanford Site to assist in restoration success, soil stabilization, and create habitat with wildlife value, where appropriate.

Current Status: Pit 9 has been operational since July 1995.

DOE/EA-0984 Deactivation of the $N$ Reactor Facilities, May 1995.

Background: This EA proposed to place the $N$ Reactor facilities in a radiologically, environmentally, and structurally stable condition that would require minimal surveillance and maintenance until D\&D of facilities is initiated. Approximately 80 facilities would be involved. Activities under the proposed action would be conducted in two phases; a 3-year deactivation phase followed by a surveillance and maintenance phase of up to 21 years.

The DOE has identified the need to place the $\mathrm{N}$ Reactor facilities in a condition that enhances worker safety, protect the environment, and reduces the costs of surveillance and maintenance in the interim.

The current conditions at the $\mathrm{N}$ Reactor facilities, if left unmitigated, present a potential threat of a contamination release to the environment or radiation exposure to workers who maintain and monitor the facilities. The current conditions at the $\mathrm{N}$ Reactor facilities also are likely to require increased surveillance and maintenance costs in the future. These conditions are a result of past operation of the $\mathrm{N}$ Reactor facilities and include the following:

- Radiologically contaminated water, sediment, and hardware in the 105-N Fuel Storage Basin, and contaminated water in the 1300-N Emergency Dump Basin

- Small quantities of radioactive fuel fragments and a potential lithium target or target fragments that might be present in the fuel storage basin

- Hazardous substances, including asbestos, transformer oils, lead shielding, contaminated resins, and various chemicals contained in tanks and buildings

- Radioactive liquids in piping systems

- Loose surface contamination and unstabilized radiation zones in buildings

- Unsealed penetrations between building interiors and the environment

- Potentially dangerous structural conditions such as damaged roofs.

FONSI: $\quad$ The FONSI was approved May 1, 1995.

The action described in the FONSI included the following: 
- Deactivate the $\mathrm{N}$ Reactor facilities to remove conditions that present a potential threat to human health and the environment and to reduce future surveillance and maintenance requirements

- Provide surveillance and maintenance after deactivation. These activities would continue until $\mathrm{N}$ Reactor and its ancillary facilities are all decommissioned

- Specific activities included in the proposed action are as follows.

- Existing applicable equipment would be restarted to support deactivation activities.

- Equipment fluids, hazardous substances, and unattached equipment and materials would be removed and characterized, packaged, and transported to the 200 Areas for use, recycling, storage, or disposal as waste.

- Basins and tanks would be drained, and contaminated water and residuals would be removed and transported to the 200 Areas for disposal.

- The 105-N Fuel Storage Basin would be inspected for irradiated fuel fragments, which would be removed, packaged, and stored in the basin awaiting future decisions regarding interim storage.

- Contaminated water from the 105-N Fuel Storage Basin and the Emergency Dump Basin would be removed, pretreated as necessary in a facility specially constructed in the 100-N Area, and transported to the 200 Area Effluent Treatment Facility for additional treatment and disposal to the soil.

- Contaminated sediment, hardware, pieces of lithium targets, and irradiated fuel spacers would be removed, packaged as necessary, and transported to the 200 Areas for storage or disposal.

- Radiation zones would be decontaminated and removed or stabilized to fix loose contaminations.

- Support systems, such as, heating, ventilation, air conditioning, water, and monitors that are not required for future environmental compliance or personnel safety would be de-energized.

- Structural repairs would be made, as necessary, for future surveillance and maintenance needs.

- Building penetrations would be sealed to prevent entry of animals, and personnel access controls would be installed.

- Routine maintenance, including inspections, and vermin and weed control would continue.

Current Status: The deactivation action at the $\mathrm{N}$ Reactor has been completed. 
DOE/EA-0985

Background:

Relocation and Storage of TRIGA Reactor Irradiated Fuel, August 1995.

FONSI:

Current Status: The neutron sources have been removed from the reactor pool and are being stored in shipping containers. All the irradiated and unirradiated fuel elements were removed and shipped in accordance to the propose action. The shutdown of the facility was completed in June 1996. All proposed activities are complete.

The Mark I TRIGA Reactor was used for research and development, and as a neutron source for the Neutron Radiography Facility, which supported the fabrication of removable core components and test assemblies for use in the FFTF. Removal of the fuel assemblies stored in the TRIGA Reactor storage pool is the last action necessary to complete the shutdown of the 308 Building.

The irradiated TRIGA fuel assemblies would be packaged in six TRIGA casks and two DOT Specification 6M containers for transportation and storage in the interim storage area that would be constructed in the 400 Area.

The existing three unirradiated fuel assemblies would be transported to another TRIGA Reactor in Denver, Colorado. However, if the three fuel assemblies could not be transferred to Denver, they may be stored at the Plutonium Finishing Plant in the 200 West Area transferred to another reactor. All, or some, of the irradiated fuel assemblies may be shipped to other TRIGA Reactors before or after the relocation of the fuel assemblies has occurred. The scope of this EA does not cover the relocation of any irradiated fuel assemblies to other reactors.

During storage, the fuel assemblies in the TRIGA casks and DOE-6M containers would be managed as spent nuclear fuel.

The FONSI was issued August 10, 1995.

DOE/EA-0986 Project L-116, 200 Area Sanitary Sewer System.

draft.

Background: This EA proposes to replace the existing sanitary sewage septic systems in the 200 Area Plateau with two modern sanitary sewage collection systems and evaporative lagoon systems for treatment and disposal. The DOE has identified a need for this proposed action to alleviate failing and overloaded sewage treatment facilities in the 200 Areas and restrain the flow of effluent to the vadose zone.

Approximately 50 sanitary sewage septic systems presently serve facilities on the 200 Area Plateau. Many of these 30- to 40-year-old systems are failing or are overloaded. Currently, about $1,514,160$ liters (400,000 gallons) of sewage per month is being transported from failed 200 Area septic systems to the 100-N Area sanitary sewer lagoon. All of these septic systems discharge septic system effluent into the 
vadose zone. This discharge contributes to the 'mounding' of groundwater below the 200 Area Plateau, which drives existing below grade contamination plumes toward the Columbia River.

One sewage collection and lagoon system would serve the 200 West Area and surrounding areas and another system would serve the 200 East Area and surrounding areas. The proposed sewage treatment system would replace about 50 septic systems presently serving facilities in the 200 Area Plateau. These systems would eliminate most liquid discharges to the vadose zone. Sewage dump stations in each area would allow sewage from failed septic systems in other areas to be transported to the proposed lagoon system for treatment and disposal.

FONSI: $\quad$ The EA has not been finalized.

Current Status: $\quad$ The draft EA has been sent to the States, Tribes, and USFWS for review. Comments have been received and are being considered. In October 1995, as advised by the Site Infrastructure Division (SID), the project including the EA, was suspended due to budget constraints and will remain in this status until reactivated by DOE.

DOE/EA-0987 Disposition of Alkali Metal Test Loops, Hanford Site, Richland, Washington, May 1995.

Background: This EA proposed to package the metallic sodium and sodium-potassium eutectic material, and associated loop hardware, for shipment offsite for recycle, reuse, and/or disposal. The sodium test loops are located in the 200 and 300 Areas. Additionally, any or all loops may be packaged appropriately, and transferred offsite for reuse. Residual sodium wetted piping and associated equipment also would be packaged for recycle disposal, as appropriate. Ancillary tankage would be cleaned in situ to remove residual sodium for potential reuse/disposal. Consideration would be given to allow an offsite entity to perform all, or part, of the proposed action.

The proposed action is a result of DOE identification of a need to disposition nonradioactive alkali metal test loops located at the Hanford Site. The disposition of the alkali metals and test loops is required because these no longer have a useful purpose.

All facilities are monitored in accordance with DOE Orders and contractor procedures and guidelines, with appropriate surveillance documentation submitted to the DOE.

In Calendar Year 1993, the sodium was placed on the Federal Excessing List to allow procurement by the private sector. Numerous potential buyers have placed firm bids for procurement of the nonradioactive sodium inventory over a multi-year period. Therefore, the sodium and sodium-potassium eutectic alloy contained within the test loops are being managed as product, pending repackaging for shipment offsite to the private sector.

The facilities that store the product are not associated with the Fast Flux Test Facility, a sodium-cooled research reactor that was directed to transition to a radiologically and industrially safe shutdown condition beginning in December 15, 1993. The 
shutdown of the FFTF is not connected with these legacy facilities, and was addressed in separate, appropriate NEPA documentation.

FONSI:

The FONSI was approved May 1, 1995.

The action described in the FONSI is as follows.

- Appropriately package the metallic sodium and sodium-potassium eutectic material, and associated loop hardware for shipment offsite for recycle, reuse and/or disposal. Additionally, any or all loops may be packaged appropriately, and transferred offsite for reuse.

- Residual sodium wetted piping and associated equipment would be packaged for recycle or disposal, as appropriate.

- Ancillary tankage would be cleaned, in situ, to remove residual sodium, to the extent practicable, for potential reuse/disposal.

- Consideration would be given to allow an offsite entity to perform all, or part, of the proposed action.

Current Status: The test loops have been sent to L.M. Manufacturing under a Cooperative Research and Development Agreement. The project is expected to be completed in the year 2001 .

Additional sodium was transferred to rail cars and shipped to a commercial facility(ies).

DOE/EA-0988

Transfer of Plutonium-Uranium Extraction Plant and N Reactor Irradiated Fuel for Storage at the 105-KE and 105-KW Fuel Storage Basins, July 1995.

Background: The EA proposed to place the irradiated fuel located at the PUREX Plant and N Reactor facilities into rail transport cask cars and move the cask cars to the 105-KE and $105-\mathrm{KW}$ Basins in the 100-K Area. The proposed action also would include fuel handling and fuel placement at the $105-\mathrm{KE}$ and $105-\mathrm{KW}$ Basins. The fuel would be stored along with the other irradiated fuel now being stored in these facilities.

This is a result of a need to remove irradiated fuel from the PUREX Plant and the N Reactor to support the deactivation and stabilization of the facilities in preparation for $D \& D$ and to reduce the cost of maintaining the facilities prior to $D \& D$.

In December 1992, DOE directed the shutdown and deactivation of the PUREX Plant because the plant no longer is needed to support the nation's weapons grade plutonium production. Some irradiated fuel that was not processed remained in the PUREX Plant. Also, the N Reactor still had some zircaloy clad (ZC) irradiated material that was still in the N Reactor after July 1991 when DOE decided to proceed with activities leading to the ultimate D\&D of the facility. 
FONSI:

The FONSI was approved on July 12, 1995.

The action described in the FONSI is as follows.

- Unprocessed irradiated fuel would be transported, by rail, from the PUREX Plant and the $105 \mathrm{~N}$ Reactor to the $105-\mathrm{KE}$ and $105-\mathrm{KW}$ fuel storage basins in the $100 \mathrm{~K}$ Area.

- The fuel would be placed in storage at the K Basins, along with fuel presently stored, and eventually would be dispositioned in the same manner as the other existing irradiated fuel inventory stored in the $\mathrm{K}$ Basins.

- A maximum of three railcar shipments of fuel would be made, two shipments from the PUREX Plant and one from N Reactor. The K Basins operational limits on allowable packaging and uranium enrichment require that the PUREX ZC fuel be transported to the 105-KW Basin. The PUREX AC fuel elements could be shipped to either the 105-KE or 105-KW Basin where the fuel would be unloaded, packaged into canisters, and placed with the other fuel already stored in the basin.

- And fuel from the N Reactor would be transferred to 105-KW Basin, unloaded, and stored with the existing fuel.

Current Status: The PUREX fuel removal action has been completed. The 100-N Basin cleanout also has been completed.

DOE/EA-0992 Decommissioning of Building 233-S, Plutonium Concentration Facility, draft.

Background: This EA proposes a phased approach to decommissioning the Plutonium Concentration Facility, Building 233-S:

- Phase I: decontaminate the structures and associated equipment

- Phase II: dismantle the complex.

The 233-S Complex began operation in 1955 to concentrate plutonium nitrate solutions from the REDOX Plant. Using an ion exchange process, the solutions passed through a resin column where the plutonium remained on the resin and impurities passed out of the system. The plutonium was chemically removed from the resin, packaged, and shipped to the PFP for further processing. In 1962, the operation was expanded to include neptunium nitrate solutions received from REDOX.

Through 1990 , decontamination activities were performed periodically to prevent spreading of contamination from the process hoods. All identified concentrated hazardous chemicals have been removed from the 233-S Building, although there could be some residual liquid in the process lines. Hazardous chemicals and asbestos containing materials have not been identified in the building in more than very minor quantities. Decontamination plans would address the presence of these substances. 
Phase I activities at the 233-S Complex would consist of removing radiological and hazardous chemical substances, equipment and materials, and asbestos insulation.

The continuous air monitoring systems within the process area would continue to operate during dismantlement operations, to alert workers to the presence of airborne plutonium.

Sampling would be implemented to identify hazardous materials present in process piping and vessels.

After removal of the buildings and foundations, a vadose zone survey of the project site would be performed to determine the extent of soil contamination. Phase II activities would be completed by grading the site to facilitate precipitation run-off and covering the area with gravel to stabilize the site.

This EA originally included D\&D of the 232-Z Building. The D\&D of 232-Z Building has been broken out into a separate EA (refer to DOE/EA-1098).

FONSI:

The RL EA Review Panel met on June 6, 1995 to determine if the draft EA should be released for review by the States and tribes. During that and subsequent meetings, it was determined that the EA would not be released and that a different regulatory approach to address decontamination and decommissioning of the 233-S facility would be pursued.

Current Status: An EA for the 233-S facility will not be issued. NEPA requirements, per Secretarial policy, will be addressed in the CERCLA Engineering Evaluation/Cost Analysis (EE/CA) for the 233-S Plutonium Concentration facility (see Section 7.0, $\mathrm{DOE} / \mathrm{RL}$ 96-93). Ultimately, an Action Memorandum will be issued that will authorize the decommissioning work to be accomplished.

DOE/EA-0993 Shutdown of Fast Flux Test Facility, Hanford Site, Richland, Washington, May 1995.

Background: $\quad$ This EA proposed to permanently shutdown the FFTF by:

- Removing fuel

- Draining and de-energizing the systems

- Removing the stored radioactive and hazardous materials

- Performing other actions to place the facility in a radiologically and industrially safe shutdown state.

The DOE has identified a need to place the FFTF in a radiologically and industrially safe shutdown condition, suitable for a long-term surveillance and maintenance phase before final D\&D. The need is based on a determination that no combination of missions for the FFTF has a reasonable probability of financial viability over the next 10 years. Disposition of the associated radioactive and hazardous materials would be necessary to place the facility in a safe shutdown condition with reduced risk to workers, the public, and the environment, while achieving the desired cost savings. 
In December, 1993, DOE determined that no combination of missions for the FFTF has a reasonable probability of financial viability over the next 10 years. Therefore, shutdown was ordered with a goal to accomplish the shutdown effort in approximately 5 years. The Fast Flux Test Facility Transition Project Plan, WHC-SD-FF-SSP-004, provides additional details regarding overall shutdown activities and requirements.

Appropriate surveillance and maintenance would be performed to prevent unacceptable risks to persons or the environment until final D\&D of the facility is completed.

FONSI: $\quad$ The FONSI was approved May 1, 1995.

The proposed actions described in the FONSI for permanently shutting down the FFTF are as follows:

- Remove the fuel, drain and de-energize the systems, remove the stored radioactive and hazardous materials, and perform other actions to place the facility in a radiologically and industrially safe shutdown state

- Perform appropriate surveillance and maintenance to prevent unacceptable risks to persons or to the environment

- Defuel the reactor core to the Interim Decay Storage and the Fuel Storage Facility by use of standard FFTF refueling equipment and operating procedures. The fuel would be replaced with irradiated nonfuel core components; 13 new nonfuel core components; and three new simulated core assemblies that otherwise would have been excessed

- Appropriately disposition two fuel assemblies that experienced a breach in the fuel cladding during irradiation, several fuel assemblies that are known gas leakers, and seven sodium-bonded metal fuel assemblies plus sodium-bonded pins that would require slightly different disposition

- Maintain the metallic sodium in a molten state until the fuel assemblies can be removed from their respective storage locations and transferred to appropriate storage

- Perform an appropriate excess evaluation of the bulk metallic sodium inventory to determine if alternative sponsors and/or uses are available

- Maintain the residua! sodium in the main portion of the FFTF's piping and equipment after the sodium and sodium potassium eutectic alloy systems with an inert gas atmosphere to prevent any chemical reactions during long term surveillance and maintenance

- Appropriately package the solid and liquid effluents from the shutdown activities that contain radioactive and/or hazardous materials. Primary consideration would be given to transportation of waste to existing treatment, storage, and/or 
disposal (TSD) facilities. Offsite TSD facilities also would be considered, as appropriate.

Current Status: As of September 1995, the FFTF has been shutdown and deactivation activities are ongoing.

Shutdown activities currently are on hold pending a DOE decision regarding a potential interim tritium/long-term medical isotope production mission. Please refer to DOE/EIS-0310 status (Section 6.0).

DOE/EA-1005

Disposition and Transportation of Surplus Radioactive Low Specific Activity Nitric Acid, Hanford Site, Richland, Washington, May 1995.

Background: $\quad$ This EA proposed to transport approximately 692,730 liters (183,000 gallons) of Low Specific Activity (LSA) nitric acid currently stored at the Hanford Site in Richland, Washington, to British Nuclear Fuel private limited company (BNF plc), located in Sellafield, England.

The proposed action resulted from a need DOE identified to disposition surplus nitric acid as part of deactivating the PUREX Plant, to reduce the risk to the environment, to reduce the cost of long-term storage, and to ensure regulatory compliance.

A specific result of cessation of PUREX Plant operations is that excess chemicals are available, including the approximately 692,730 liters ( 183,000 gallons) of slightly radioactively contaminated nitric acid. The material is stored in four storage tanks at the PUREX Plant. The average concentration of the nitric acid is approximately 10 moles per liter. The total quantity of plutonium in the nitric acid is less than 0.3 gram ( 0.01 ounce). The total quantity of uranium is approximately 7,395 kilograms ( 16,300 pounds). The fissile components of the nitric acid consist of the negligible inventory of plutonium(238 and 239) and approximately 72 kilograms (158 pounds) of uranium 235 .

As part of the BNF plc operations, the uranium contained in the LSA nitric acid would be recovered and converted to solid uranium trioxide. The DOE would retain title to an amount of the solid uranium trioxide that is equivalent to the amount recovered from the LSA nitric acid. The current plans are to return the solid uranium trioxide material to the Hanford Site for storage with the existing inventory pending final disposition. The small quantity of plutonium would not be recovered for return to DOE, but would remain within the processing streams associated with routine BNF plc operations.

FONSI: $\quad$ The FONSI was approved May 15, 1995.

The proposed actions described in the FONSI are as follows:

- Transfer the nitric acid from its existing location in the PUREX Plant to transport containers designed and fabricated to appropriate specifications

- Secure the containers on a truck trailer and radiological monitor by trained personnel using prescribed procedures and equipment prior to release 
HNF-SP-0903, Rev. 7

- Inspect the containers and trailers before transport to ensure appropriate standards, specifications, and regulations, including U.S. Department of Transportation guidelines, and carrier security demands are met. Approximately 52 shipments from the Hanford Site to an east coast port would be required to transfer the entire inventory on nitric acid to BNF plc. Transport time from the Hanford Site to the east coast would be approximately 4 days for each shipment.

- Ship the nitric acid from any of three east coast ports (Portsmouth, Virginia; Baltimore, Maryland; and Newark, New York). The specific port for each shipment would depend on the carriers' shipping schedule.

- Recover the uranium contained in the nitric acid and convert to solid uranium trioxide (BNF plc action). The DOE owned solid uranium trioxide would be transferred to suitable storage containers and transferred to interim storage in the BNF plc storage facility. Current plans are to return this material to the Hanford Site for storage with the existing inventory pending final disposition.

- Subsequent to removing the entire inventory of nitric acid from the PUREX Plant, stabilize the storage tanks (e.g., rinse and isolate) and place into a condition suitable for long-term surveillance, pending decommissioning of the PUREX Plant. Rinse solutions would be transferred to existing waste management facilities on the Hanford Site for treatment, storage, and/or disposal.

- Return transport containers to the Hanford Site, decontaminate as necessary, and reuse or disposition as appropriate.

Current Status: Shipments of the nitric acid from the PUREX Plant have been completed.

\section{DOE/EA-1030 Characterization of Stored Defense Production Spent Nuclear Fuel and Associated Materials at Hanford Site, Richland, Washington, March 1995.}

Background: This EA proposed to characterize stored defense production spent nuclear fuel and associated materials on the Hanford Site. DOE has identified a need for characterization activities that would establish a basis for determining the types of interim storage modes that would be compatible with the spent nuclear fuel material (SNFM) in its present condition, and the kind and extent of processing, if any, the SNFM would require to make it compatible with alternative storage modes.

Currently, 1,150 metric tons (1,268 tons-short) of uranium (MTU) of irradiated $\mathrm{N}$ Reactor fuel are stored in 3,666 open canisters in the 105-KE Basin and $958 \mathrm{MTU}$ of $\mathrm{N}$ Reactor fuel are stored in 3,815 sealed canisters in the 105-KW Basin in the 100-K Area. Each basin also contains a small amount of irradiated single pass reactor (SPR) fuel [0.1 MTU (0.11 tons-short)] in 105-KW and 0.4 MTU ( 0.44 tons-short) in 105-KE Basin. In addition, there are 2.9 MTU (3.2 tons-short) of SPR and 0.5 MTU (0.55 tons-short) of N Reactor fuel stored in the PUREX Plant in the 200 East Area. The $\mathrm{N}$ Reactor fuel was discharged from the reactor between 8 and 25 years ago. Most of the SPR fuel is residual material from the 105-KE and $105-\mathrm{KW}$ and is over 20 years old. The total stored spent defense production nuclear fuel (SNF) amounts to about 2,110 MTU (2,325 tons-short). 
An estimated 12 percent of the fuel elements have cladding damage as a result of discharge and subsequent handling operations and 90 percent of the canisters are estimated to contain at least one damaged fuel element. In addition, some fuel has been damaged as a result of corrosion during storage.

The need for characterization arises because:

- Some fuel, if it were to become bare and dry, might auto ignite releasing radioactive material to the atmosphere, thus, auto ignition conditions need to be determined.

- The condition of material in canisters in 105-KW Basin is unknown, but may contain some uranium hydride, a reactive corrosion product.

- Proceeding with either wet or dry storage concepts for SNFM in the 100-K Area Basins without the technical basis provided by characterization would not be prudent in terms of safety and environmental protection.

FONSI: $\quad$ The FONSI was approved March 13, 1995.

The proposed action described in the FONSI is as follows:

- Obtain samples of spent nuclear fuel and associated materials stored in the 100-K Area Basins.

- Transport the samples by truck in commercially available NRC licensed casks to the 327 Building in the 300 Area.

- Subject the samples to physical and chemical characterization.

- Develop a range of alternative fuel conditioning technologies based on the characterization results.

- Return unused sample portions to storage in the 100-K Area Basins.

- Dispose of characterization wastes in approved disposal sites in the 200 Areas.

Current Status: The spent nuclear fuel characterization proposed actions are proceeding as scheduled. Several fuel elements and samples of basin sludge have been transferred from the $\mathrm{K}$ Basins to the Hanford Site laboratories for characterization. Characterization of the SNF fuel and basin sludge began in 1995 and is ongoing, and will continue through final disposition of the fuel as addressed in DOE/EIS-0245 (Section 6.0).

DOE/EA-1098 Decommissioning and Decontamination of Building 232-Z at the Hanford Site, Richland, Washington, draft.

Background: $\quad$ None available as of September 1998.

FONSI: $\quad$ The EA is on hold until further notice from the DOE-RL Programs office. 
Current Status: Because of schedule changes regarding 232-Z, 233-S has been broken out as a separate EA. Refer to DOE/EA-0992.

The EA has been delayed because of new information concerning the plutonium inventory that indicated there was more there than originally expected. A Memorandum of Understanding (MOU) between EPA and DOE regarding D\&D has been issued that allows DOE to perform D\&D action under CERCLA regulatory authority as (usually) non-time-critical removal actions. The environmental review of this proposed action may occur under CERCLA.

\section{DOE/EA-1111 K Pool Fish Rearing, Hanford Site, Richland, Washington}

Background: $\quad$ This EA proposal was to respond to a request by the Yakima Indian Nation (YIN) to lease surplus facilities at the $105-\mathrm{KE}$ and $105-\mathrm{KW}$ filter plant pools (K Pools) for fish rearing activities. These fish rearing activities would be: (1) business ventures by the YIN or other parties with public and private funds and (2) long-term enhancement and supplementation programs for game fish populations in the Columbia River Basin.

The proposed action is to enter into a use permit or lease agreement with the YIN or other parties who would rear fish in the 100-K Area Pools. The proposed action would include necessary piping, pump, and electrical upgrades of the facility; cleaning and preparation of the pools; water withdrawal from the Columbia River, and any necessary water or waste water treatment; and introduction, rearing, and release of fish. Future commercial operations may be included.

The fish-rearing program eventually would include raising fall chinook salmon juveniles, white sturgeon, coho salmon, steelhead-trout, rainbow trout, and channel catfish, walleye, bass, crappie, and other warm water species. Only chinook salmon would be released into the Columbia river.

FONSI: $\quad$ The FONSI was signed December 20, 1996.

Current Status: The pools presently are inactive.

\section{DOE/EA-1112 Sludge and Solid Residue Stabilization at the Plutonium Finishing Plant, Hanford Site, Richland, Washington}

Background: The purpose for this EA is to continue reducing worker exposure to radiation at the Plutonium Finishing Plant (PFP). The exposure to the workers would be reduced incrementally as sludges and residues remaining in the process areas are removed, stabilized, and moved to vault storage. The proposed action is an extension of the action analyzed in the PFP Sludge EA (DOE/EA-0978). The scope of this EA would install and operate up to nine additional laboratory-size muffle furnaces within three to five glovebox enclosures located in PFP while continuing operation of the two muffle furnaces currently operating in accordance with DOE/EA-0978. The scope also would allow stabilization of additional chemically reactive sludges and solid residues beyond those allowed via DOE/EA-0978. 
Alternatives considered in this EA included No Action, Disposal, Processing, Offsite Treatment and Storage, and Slow Stabilization. The proposed action of this EA to add more furnaces and continue stabilization of sludges and process residues was an interim action pending completion of the PFP Stabilization EIS analysis and its associated Record of Decision (see Section 6.0, DOE/EIS-0244).

The bounding accident postulated for this operation was determined to be a flammable gas deflagration inside the glovebox, which breaches the glovebox, and disperses 126 grams of plutonium into the room. As a result of the analysis, there would be no offsite or onsite population fatal cancers attributable to this exposure.

FONSI: $\quad$ The FONSI was approved November 21, 1995.

Current Status: Furnaces have been installed, and sludge stabilization activities are continuing.

DOE/EA-1123 Transfer of Normal and Low-Enriched Uranium Billets to the United Kingdom, Hanford Site, Richland, Washington

Background: This EA proposed to transfer approximately 710,000 kilograms $(1,565,256$ pounds $)$ of unneeded normal and low-enriched uranium to the United Kingdom from the Hanford Site, reducing long-term surveillance and maintenance burdens on the Hanford Site.

The surplus uranium billets would be repackaged, as necessary, and placed into appropriate Department of Transportation shipping containers. The material would be transported from the Hanford Site, overland to the port of Seattle, in approximately 45 truck shipments. The material would be transferred to a commercial cargo vessel and transported to the United Kingdom.

Alternatives to the proposed action included the No Action Alternative, alternative uses, alternative U.S. ports, and alternative transportation modes.

FONSI: $\quad$ The FONSI was approved November 9, 1995. The proposed action in the FONSI is in accordance with the proposed action in the EA.

Current Status: The transfer of the uranium billets has been completed.

DOE/EA-1135 Offsite Thermal Treatment of Low-Level Mixed Waste, Hanford Site, Richland, Washington

Background: This EA analyzes the potential offsite thermal treatment of low-level mixed waste generated at the Hanford Site.

With the February 23, 1998 publication of the City of Richland's SEPA EIS on the ATG facility, this EA has been reactivated. On March 18, 1998, the information in the SEPA EIS was compared to the 1996 draft EA to identify any new or changed information. The RL NEPA Panel reviewed the draft EA and recommended a FONSI be issued. A recommendation letter, final EA and draft FONSI were prepared. A comment letter arrived on April 17, 1998. The comments have been considered, a response prepared, and changes were made to the EA and draft FONSI. 
Comments have been received by phone and e-mail and have been considered. Responses to those comments and offers to meet with the commentors were sent on July 17, 1998. A two week comment period was offered, closing July 31,1998 . A meeting with one of the commenters was held on August 12. Also present at the meeting were Ecology and ATG. Comments were incorporated, and the EA was approved in May of 1999.

FONSI: $\quad$ The FONSI was approved May 6, 1999. The proposed action in the FONSI is in accordance with the proposed action in the EA.

Current Status: Work is ongoing to implement the proposed action.

DOE/EA-1142 200 West Area Raw Water Line,

Hanford Site, Richland, Washington

Background: This EA proposed to improve the raw water supply to the 200 West Area to ensure adequate water for fire protection, process water, and potable water uses. The proposed action would allow for the construction of a raw water pipeline from 2901-Y to the 282-W pumphouse to connect the existing water export lines directly to the water grid that services the 200 Areas.

Alternatives considered were the No Action Alternative, construction alternatives to preserve more habitat, and the alternative of drilling wells. Construction alternatives included alternate routes, placing the pipeline above ground, and using a different trenching technique to install the pipeline. The principal environmental issue was the disturbance of shrub-steppe habitat.

FONSI: $\quad$ No FONSI has been issued for this EA.

Current Status: $\quad$ Notification letters to the State and tribes and interested parties were sent on December 20,1995. The draft EA was transmitted to the State, Tribes, and interested parties on March 4, 1996, for comment. This EA has been placed on hold.

DOE/EA-1177 Salvage/Demolition of 200W, 200E, and 300 Areas Steam Plants, Hanford Site, Richland, Washington

Background: This EA proposes to salvage and demolish the 200 West Area, 200 East Area, and 300 Area Steam Plants and their associated steam distribution piping, equipment, and ancillary facilities. Activities include the salvaging and recycling of all materials, wastes, and equipment where feasible, with waste minimization efforts utilized. It is planned to remove all foundation and concrete footings and return the areas to ground level for potential reuse.

The transition of the Hanford Site mission from defense production to a restoration mission has reduced the large demand for steam required to support defense operations. The 200 West Area Steam Plant was shut down in fiscal year 1995 and is currently in surveillance and maintenance awaiting decommissioning. The estimated annual cost for access controls and surveillance and maintenance of the steam plants would escalate over time as the facilities deteriorate. The 200 East Area and 300 Area Steam Plants are currently in operation and are expected to be shut down in 
the near future. DOE needs to eliminate costly access controls, surveillance and maintenance activities associated with the deactivation of infrastructure and general purpose facilities.

FONSI: $\quad$ The FONSI was approved September 30, 1996.

Current Status: DOE is prioritizing salvaging/demolition activities.

\section{DOE/EA-1178 300 Area Steam Replacement, Hanford Site, Richland, Washington}

Background: $\quad$ This EA proposes an energy conservation measure for a number of facilities in the 300 Area of the Hanford Site. The measure includes replacing the existing centralized steam plant with heating units for individual facilities in the 300 Area. Implementation of the proposed action would reduce energy consumption and facility maintenance.

Steam to support process operations and facility heating in the 300 Area is currently produced by a centralized steam plant and piped to various facilities. This boiler was constructed during the 1940s and, because of its age, is not efficient, requires large operating and maintenance staff, and is not reliable.

FONSI: $\quad$ The FONSI has been issued as of September 30, 1996.

Current Status: The activity is complete.
200 Area Emergency Facilities Campus, Hanford Site, Richland, Washington

Background: This EA proposes to enhance fire protection, hazardous materials response, and emergency services to protect Hanford Site workers, property, and the environment. Activities include the upgrading the existing sewer system and providing secondary sanitary water supply to the $609 \mathrm{~A} / \mathrm{C}$ Fire Station Complex; moving an existing modular office facility to the west of the $609 \mathrm{~A} / \mathrm{C}$ Fire Station Complex to serve as the Emergency Services Headquarters; renovating the 609A/C Buildings into adequate living quarters and vehicle apparatus facility; and adding a new covered Vehicle Storage Area just south of the $609 \mathrm{~A} / \mathrm{C}$ Buildings.

FONS1: $\quad$ The FONSI was issued March 4, 1997.

Current Status: Work is in progress.

DOE/EA-1185 Management of Hanford Site Non-Defense Production Reactor Spent Nuclear Fuel, Hanford Site, Richland, Washington

Background: This EA proposes to place the Hanford Site's non-defense production reactor Spent Nuclear Fuel (SNF) in a radiologically- and industrially-safe, and passive storage condition pending final disposition. 
FONSI: $\quad$ The FONSI was issued March 28, 1997.

Current Status: Work is ongoing to implement the proposed action.

DOE/EA-1189 Solid Low-Level Waste (LLMW) Non-Thermal Treatment

Background: This EA proposes to non-thermally stabilize or encapsulate contact-handled low-level mixed waste to meet Resource Conservation and Recovery Act land disposal requirements.

FONSI: $\quad$ The FONSI was issued September 29, 1998.

Current Status: Work is ongoing to implement the proposed action.

DOE/EA-1203 Trench 33 Widening in 218-W-5 Low-Level Burial Ground, Hanford Site, Richland, Washington

Background: This EA proposes to widen and operate the existing and unused disposal trench 33 within the 218-W-5 burial Ground in the 200 West Area for disposal of LLW. The widening of trench 33 would allow for disposal of both boxed and large-packaged Category $1 \mathrm{LLW}$. This would provide for more cost-effective land use and increase the capacity of the Low-Level Burial Ground (LLBG), without an increase to the footprint of the LLBG.

FONSI: $\quad$ The FONSI was issued July 28, 1997.

Current Status: Trench 33 is receiving waste.

DOE/EA-1210 Lead Test Assembly Irradiation and Analysis, Watts Bar Nuclear Plant. Tennessee and Hanford Site, Richland, Washington

Background: This EA proposes to conduct a lead test assembly program to confirm the viability of using a commercial light water reactor (CLWR) to product tritium. The EA tiers from the Programmatic Environmental Impact Statement for Tritium Supply and Recycling. The EA covers those activities necessary to conduct tests involving irradiation of tritium-producing burnable absorber rods (TPBARs) in a CLWR and post-irradiation examination of the TPBARs. The proposed action would involve preparation and analysis activities at DOE facilities and irradiation of the TPBARs at a commercial nuclear power reactor (Watts Bar Nuclear Plant, Tennessee).

FONSI: $\quad$ The FONSI was issued July 22, 1997.

Current Status: Work has been initiated to implement the proposed action. 


\section{DOE/EA-1211 Relocation and Storage of Isotopic Heat Sources, Hanford Site, Richland, Washington}

Background: $\quad$ This EA proposes to construct and operate a storage site within the Central Waste Complex in the 200 West Area of the Hanford Site for the storage of isotopic heat sources currently stored in the 324 Building. There are 34 isotopic sources: 30 sealed isotopic heat sources manufactured in the 324 Building as part of a bilateral agreement between the Federal Republic of Germany and DOE; two production demonstration canisters; and two instrumented canisters. The agreement was for developing processes for the treatment and immobilization of high-level radioactive waste.

FONSI: $\quad$ The FONSI was issued June 6, 1997.

Current Status: The sources have been relocated and are being stored in the 200 West Area of the Hanford Site.

DOE/EA-1259

Background:

Current Status:

\section{WPPSS (Supply System) Sublease for an Aluminum Smelter Plant}

On May 1, 1998 the Manager-RL determined that an EA is the appropriate initial level of NEPA review for this proposed action. The draft EA was sent for public comment in August 1998.

This EA was terminated December 8, 1998, due to lack of response from the proponents to a request for further information to be used to respond to public comments.
DOE/EA-1260

Background:

FONSI:

Current Status:

\section{Transfer of 1100 Area, Southern Rail Connection, and Rolling Stock}

The proposed action is to transfer ownership of the Hanford Site 1100 Area north of Richland, Washington, and the Hanford Southern Rail Connection and rolling stock to the Port of Benton.

The FONSI was issued August 27, 1998.

Implementation activities for the proposed action have been completed.
DOE/EA-1276

\section{Widening Trench 36 of the 218-E-12B Low-Level Burial Ground}

This environmental assessment was prepared to assess potential environmental impacts associated with the proposed action to widen and operate unused Trench 36 in the 218-E-12B Low-Level Burial Ground for disposal of low-level waste.

FONSI: $\quad$ The FONSI was issued February 11, 1999.

Current Status: The proposed action has been completed. 
HNF-SP-0903, Rev. 7

DOE/EA-1319 Disposition of Surplus Hanford Site Uranium, Hanford Site, Richland, Washington

This environmental assessment was prepared to assess potential environmental impacts associated with the proposed action to disposition 1,866 metric tons of Hanford Site uranium that has been identified as surplus material. DOE needs to (1) relocate potentially saleable Hanford Site surplus unirradiated uranium to the DOE's Porstmouth Site near Portsmouth, Ohio, for future beneficial use and (2) provide onsite management of Hanford Site surplus uranium that is not considered readily saleable.

FONSI: $\quad$ The FONSI was issued June 15, 2000.

Current Status: Implementation activities for the proposed action have been initiated. 
HNF-SP-0903, Rev. 7

This page intentionally left blank. 
HNF-SP-0903, Rev. 7

\subsection{MISCELLANEOUS ENVIRONMENTAL ASSESSMENTS}

This chapter provides summary information on miscellaneous EAs.

DOE/RW-0070 Reference Repository Location,

Hanford Site, Richland, Washington, December 1984.

This is a NWPA document.

Background: In February 1983, the DOE identified a reference repository location on the Hanford Site as one of nine potentially acceptable sites for a mined geologic repository for spent nuclear fuel and radioactive HLW. The reference repository Basalt Waste Isolation Project (BWIP) would be within the Pasco Basin, a 4,850-square kilometer (1,872-square mile) topographic depression in the Columbia Plateau and, more specifically, in the central part of the Cold Creek syncline.

On the basis of the evaluations reported in this EA, the DOE found that the Hanford Site qualified under the guidelines for potential site locations. The DOE also found that the Hanford Site was suitable for site characterization because the evidence did not indicate the site would not be able to meet the guidelines. The DOE nominated the Hanford Site as one of five sites suitable for characterization.

The EA is a three-volume set.

FONSI: $\quad$ A FONSI was not required under the NWPA.

Current Status: The BWIP was terminated in 1987.

$\begin{array}{ll}\text { ELA/WPR/77-3 } & \text { Environmental Impact Assessment: Coring Well, } \\ & \text { Hanford Reservation, Richland, Washington, March } 1977 .\end{array}$

Background: This EIA proposed drilling a core well (ARH-DC-2) to test the geologic and hydrologic properties of the basalt rocks underlying the Hanford Site. The data were needed to support the National Waste Terminal Storage Program.

The proposed core well was to be located approximately 18 meters (59 feet) southwest of the existing deep drill hole ARH-DC-1, 183 meters (600 feet) north of the 200 East Area boundary fence, about 10.6 kilometers $(6.6$ miles) from the nearest active reactor site, and about 10 kilometers $(6.2$ miles $)$ from the nearest section of the Columbia River. The core well was to have been approximately 1,006 meters (3,300 feet) deep and 10 centimeters ( 4 inches) in diameter.

Special Notice: The ERDA Assistant Administrator for Environment and Safety determined that an EA was unnecessary for exploratory borehole ARH-DC-3, based on the close proximity of the hole to core well ARH-DC-2 (analyzed in this EIA).

FONSI: $\quad$ A FONSI was not required because the EIA was written before the CEQ's final regulations were issued.

Current Status: The EIA was never finalized because borehole construction was terminated. 
HNF-SP-0903, Rev. 7

RHO-BWI-CD-19-REV Constructing a Near-Surface Test Facility,

Hanford Reservation, Richland, Washington, February 1978.

Background: Refer to DOE/EA-0052 (Section 2.1) for information concerning this project. 


\subsection{U.S. ATOMIC ENERGY COMMISSION, ENVIRONMENTAL STATEMENTS (WASH) ${ }^{1}$ - HANFORD SITE ${ }^{2}$}

This chapter provides summaries of WASH EAs.

WASH-1510 Fast Flux Test Facility, U.S. Atomic Energy Commission, Hanford Reservation, Richland, Washington, May 1972.

Background: $\quad$ The FFTF is a nuclear reactor complex designed for irradiation testing of fuels and materials to be used in future sodium-cooled fast breeder power reactors. This R\&D facility is in the AEC's LMFBR program. The design and construction of the FFTF were authorized in 1966 and 1967, respectively.

The heart of the complex, a 400-MWt nuclear reactor fueled with a mixture of plutonium-uranium dioxide, provides a fast neutron flux irradiation environment similar to that of an LMFBR. Radioactive waste materials were generated at the FFTF site as a result of operation and maintenance of the reactor and reactor systems. This liquid, solid, and gaseous waste was produced through fission in the fuel and activation of reactor structural materials, primary sodium coolant, and the reactor cover gas. The plutonium in the fuel was also a source of radioactivity.

The FFTF design guidelines emphasized use of existing technology. The facility was designed to operate reliably, safely, and with minimal environmental effects. The design effort had been and continues to be supported by a strong $R \& D$ program with emphasis on testing. Safety features of the FFTF included: (1) duplicate and independent plant monitoring systems that sensed any abnormalities and shut down the plant, (2) a low-pressure coolant system, (3) a guard vessel surrounding the reactor vessel, and (4) a separate plant containment structure.

The FFTF emitted vapor to the air. The FFTF was designed so that there was no planned, continuous, or intermittent releases of radioactive effluents to the environment, other than radioactive gas leaks that might have occurred through seals, by diffusion through structural materials, or during accident conditions.

Radioactive waste was collected and shipped to a remote processing and storage site within the Hanford Site or to another location approved by the AEC. Transfer of radioactive material within the Hanford Site was in accordance with the AEC onsite procedures and regulations. Any offsite shipments of radioactive material were in compliance with regulations established by the AEC and the U.S. DOT.

The Hanford Site was selected because of proximity to project and design resources; availability of qualified management and technical personnel; availability of improved communications and travel facilities; extensive experience in the development of plutonium fuels; and experience in the design, construction, and operation of large power reactors such as the Hanford Site N Reactor.

Alternatives:

1. FFTF (the preferred alternative)--The existing fast flux reactors, Experimental Breeder Reactor No. II and Fermi, were not designed originally as fuel and

' The WASH documents were issued by the AEC.

${ }^{2}$ All WASH documents predated the CEQ's regulation on the need for RODs. 
material test facilities. These reactors could provide an interim measure of fast flux tests, but were inadequate to accomplish the in-depth testing needed for LMFBR demonstration and commercial plants. Both Experimental Breeder Reactor No. II and Fermi had limitations as to neutron flux spectrum, sodium coolant conditions typical of the future LMFBRs, testing capability required for highly instrumented and controlled fast flux environment tests, and adequate test space. As a result of the series of thermal neutron flux and fast neutron flux test facility studies, the AEC decided in 1965 that construction of an FFTF must be undertaken if the national objectives of the LMFBR R\&D program were to be achieved.

2. Thermal Flux Test Facilities--Fast breeder reactor fuels and materials required a test environment of high-temperature flowing sodium, a fast neutron flux environment, and high sodium temperature differentials to adequately duplicate the behavior of LMFBR fuels. None of the existing thermal flux reactors could be altered to provide a large enough fast flux and a proper environment for use in the LMFBR fuels and materials test program.

Current Status: The FFTF was built between 1969 and 1978 and achieved full power in 1980 . Operations began in 1982. The FFTF developed advanced nuclear fuels and materials for liquid metal reactors. It was used to test technologies essential to space power, fusion energy, medical and commercial isotope production, and eventually to eliminate nuclear HLW. Canada, Japan, and several European nations used the reactor to support development of their domestic advanced energy systems. As of September 1995, the facility has been shutdown (Reference DOE/EA-0993).

WASH-1520

Contaminated Soil Removal Facility, U.S. Atomic Energy Commission, Hanford Reservation, Richland, Washington, April 1972.

Background: This environmental statement proposed removing plutonium-contaminated soil from the floor of an existing enclosed trench (Z-9 in the 200 West Area) used between July 1955 and June 1962 for subsurface disposal of plutonium-contaminated liquids. Liquid waste from the PFP had been discharged to enclosed trenches since startup of the facility in 1950. Most of the plutonium in the liquid waste was retained by the soil and held within a few vertical feet of the point of release. Because of the quantity of plutonium contained in the soil, special precautions and emergency plans were required that were not required for other enclosed trenches.

In this environmental statement, the DOE proposed constructing facilities at the Z-9 trench to permit excavation of contaminated soil, adding equipment to the existing PFP for recovering plutonium from the contaminated soil, and constructing an underground storage vault for interim storage of contaminated soil.

Removal of the plutonium-contaminated soil would eliminate the need for special precautions and the necessary emergency plans to ensure the safe storage of plutonium. Because of the quantity of plutonium contained in the soil of the Z-9 trench, a nuclear chain reaction was considered. Even though the probability of this occurrence was thought to be remote, it was determined that the removal of the contaminated soil would eliminate any possibility of such an event. 
It was estimated that 100 kilograms (2,205 pounds) of plutonium were contained in the 51-cubic meter (66.71-cubic yard) volume of contaminated soil to be removed from the Z-9 Trench. It was believed that more than three-fourths of the plutonium in the soil (worth approximately $\$ 3,000,000$ ) could be economically recovered in the nearby PFP. The proposed operation also permitted extensive evaluation of soil-dissolution and plutonium-extraction techniques. Residues from the extraction operations and contaminated soil with insufficient plutonium to permit economical extraction would be packaged in plastic bags, placed in steel drums, and stored in a new underground storage vault. Because the contaminated soil would be packaged in steel drums, the soil could be moved to another location.

The proposed operation also would permit the extensive evaluation of techniques for removing and measuring contamination in soil. Appropriate adjustments could be made in the excavation plans as the soil was removed and the plutonium measurements were made.

The Hanford Site is interspersed with chemical separation facilities, underground pipelines and tanks, and supporting facilities in the 200 West Area. The aboveground structures of the Contaminated Soil Removal Facility would be removed after the soil removal operations were complete. These operations took place from 1974 to 1976. The facilities would be designed to avoid release of any contaminated soil during soil recovery and storage.

Alternatives: $\quad$ Alternatives to the proposed Contaminated Soil Removal Facility are as follows:

- The preferred action alternative would involve changes in the scope of the recovery concepts (i.e., hand excavation versus remote mechanical removal and vault storage of the contaminated soil without leaching).

- The no-action alternative would involve continued retention of the plutonium in the enclosed trench.

Current Status: The Contaminated Soil Removal Facility is now decommissioned and waste has not been placed in the Z-9 trench since June 1962. $\begin{array}{ll}\text { WASH-1521 } & \text { Radioactive Waste Evaporator and Auxiliaries, U.S. Atomic Energy Commission, } \\ & \text { Hanford Reservation, Richland, Washington, April } 1972 .\end{array}$

Background: This environmental statement proposed that the radioactive waste generated by operations on the Hanford Site could be safely stored and processed according to an established Waste Management Program. The AEC was converting highly radioactive liquid waste stored in buried, steel-lined, concrete tanks into solid, retrievable salt cake. The three waste evaporators used in the program had limited evaporative capacity and a limited heat removal capability in the waste tanks. This restricted the rate and efficiency of converting the liquid waste to salt cake. The storage tank volume close to the existing evaporator facilities was not sufficient to contain all of the resulting salt cake.

The environmental statement asserted that the operation of the radioactive waste evaporator and auxiliaries would alleviate the previously mentioned problems. The radioactive waste evaporator would be an evaporator-crystallizer unit that would 
process twice as much liquid waste as the existing three evaporators combined. The new unit would be located near underground storage tanks suitable for storing additional waste for solidification.

The auxiliaries would consist of pipelines and equipment modifications to allow the use of existing tanks for salt cake storage. The auxiliary tanks also would allow existing tanks to be used for neutralizing the excess alkalinity in concentrated liquid waste, and as concentrated waste coolers. The neutralization facility was necessary to solidify the fraction of the liquid waste that could not be converted to a salt cake by evaporation alone. The cooling facility would increase the evaporation rate for liquid waste by 10 to 20 percent.

The radioactive waste evaporator-crystallizer would operate at full capacity for about 3 years or until the backlog of liquid radioactive waste on the Hanford Site had been reduced to salt cake. It would be operated either at reduced rates or intermittently to process the remaining waste (i.e., those requiring an aging period of 3 to 5 years before they could be solidified). At the end of its useful life, the radioactive waste evaporator-crystallizer was to be decommissioned.

Effluents from the radioactive waste evaporator-crystallizer would include process and steam condensates, cooling water, human waste, contaminated solid waste, and ventilation air. Those effluents, which would contain radionuclides, would be treated to reduce their radionuclide concentration to ALARA levels before being discharged to an enclosed trench. The total yearly discharges contained in the condensates were estimated to be less than 0.2 curie of cesium-137, 0.01 curie of strontium- 90 , 0.07 curie of ruthenium-106, and 0.01 gram of plutonium-239. These releases would be in concentrations below applicable federal guidelines, and there would be no measurable effect at or near the Columbia River.

Alternatives: The alternatives included the following:

- The preferred alternative was to build the radioactive waste evaporator-crystallizer facility

- The continued use of the existing evaporators, which would have a combined capacity of less than one-half of the radioactive waste evaporator-crystallizer system, would require approximately 5 years more to complete the in-tank solidification of the waste being stored at the Hanford Site

- The use of other dewatering concepts, including atmospheric evaporation of water, calcination of waste, sorption of water by chemicals, and air drying.

Current Status: In 1980, the 242-S Evaporator was shut down and placed in standby condition three. Standby condition three means that no future use of the facility as an evaporator is foreseen. The 242-S Evaporator is being used as an alarm monitoring station for selected 200 West Area tank farms. The facility is locked and entered only to obtain specific alarm readings. 


\subsection{U.S. ENERGY RESEARCH AND DEVELOPMENT ADMINISTRATION EVIRONMENTAL IMPACT STATEMENTS - HANFORD SITE ${ }^{1}$}

This chapter provides summaries of ERDA documents.

ERDA-1538

Background:

Alternatives:
Waste Management Operations, Hanford Reservation, Richland, Washington, final, December 1975.

Since 1944, when the first Hanford Site facilities began producing plutonium for the Manhattan Project, radioactive waste has been generated. Consequently, there has been a continuous and evolving program for waste management.

This document was written for the Waste Management Operations Program at the Hanford Site. The draft statement was issued as WASH-1538. This statement reassessed the environmental impacts associated with continuing the Hanford Site Waste Management Operations Program to provide information for use in planning and decisionmaking to ensure that further waste management practices would be conducted to minimize adverse environmental consequences. The foreword of this document provided an introductory summary of: (1) the policies, plans, and standards applicable to the Hanford Site Waste Management Operations Program; (2) the Waste Management Operations Program; and (3) the programs and activities on the Hanford Site that were not covered in this EIS.

The quantities of materials released to the environment from Hanford Site operations were anticipated to decline as a result of (1) modifications of old and construction of new facilities and (2) curtailment of production activities.

Waste generated by production, $R \& D$, and other programs and activities at the Hanford Site were covered in this document. This document did not cover the alternatives and/or costs and benefits with respect to the production of special nuclear materials or the operation of R\&D programs. The operation of $\mathrm{N}$ Reactor and the PUREX Chemical Processing Plant were beyond the scope of this document.

Because the Waste Management Operations Program on the Hanford Site is an ongoing program, many of the long-term and short-term options for the control, handling, and disposal of radioactive waste were in various stages of R\&D. Although the status of these R\&D efforts was discussed in the statement, some of these R\&D programs required their own Environmental Statements at a later time.

Ultimate-disposal R\&D would be reevaluated periodically so that an appropriate impact statement relating to ultimate disposal could be prepared as soon as sufficient information was available.

Alternatives to HLW treatment were as follows:

- The preferred alternative was to continue the present program, which was solidifying the liquid waste to a salt cake form and constructing additional DSTs to contain the liquids during interim periods.

\footnotetext{
${ }^{1}$ All ERDA documents predated the CEQ's regulation on the need for RODs.
} 
- Shutdown of N Reactor in 1978,1983 , or 1990 , which would lead to ending the generation and processing of most new radioactive waste.

- Shutdown of PUREX in 1978, 1983, or 1990. Two options were presented: first, shutdown after processing all $\mathrm{N}$ Reactor fuel currently on hand; and second, shutdown now with the existing inventory of irradiated $N$ Reactor fuel either shipped offsite for processing or stored onsite without processing.

- Discontinue solidifying salt cake with the goal of converting the liquid HLW to a better solid form for interim storage, or holding the remaining liquid waste until an ultimate disposal method was developed and implemented. Implicit in these options was the need to construct new DSTs.

Current Status: The EIS was final as of December 1975.

\section{ERDA-1550 Final Environmental Impact Statement: High-Performance Fuel Laboratory, Hanford Reservation, Richland, Washington, September 1977.}

Background: The HPFL was to provide pilot-scale tests for safe, fast breeder reactor fuel manufacturing. The experience of designing, constructing, and operating the HPFL would have been used in future commitments to commercial fuel fabrication plants.

During normal HPFL operations, it was anticipated that extremely small quantities of noxious substances might be released into the atmosphere in spite of the multiple filtration features of the ventilation system. Releases of nonradioactive noxious substances into the atmosphere would have been within acceptable limits and were not expected to cause any health effects. The calculated doses to the population resulting from radioactive releases were to be negligible.

Benefits from the fuel fabrication development program and the HPFL would have been as follows:

- To society--Improved safeguards, reduced personnel exposure, releases in accordance with ALARA, and minimum generation of waste.

- To technology--Development and evaluation of improved fuel fabrication processes and equipment; simplification of current fuel fabrication and assembly processes; demonstration of online, timely inventory control and accountability: and demonstration of online product inspection.

- To industry--Demonstration of fabrication methods; generation of data to determine capital investment requirements; creation of a pilot line for process and equipment evolution; demonstration of process; demonstration of the use and handling of light-water, reactor-derived, recycle plutonium; demonstration of industrial-scale equipment and processes; and participation in program planning. 
Alternatives: The alternatives for the project were as follows.

- The preferred alternative was to build the HPFL in the 400 Area of the Hanford Site.

- Alternative technologies could have been examined (e.g., the mixed oxide dry powder fuel fabrication technique).

- Alternative designs identified and considered during the first phases of the HPFL exhibited higher costs and greater difficulties of program operation than the proposed facility.

- Potential use through modification of existing facilities at the Hanford Site was considered in the initial design effort.

- Each of the other alternative sites for the HPFL had its own particular set of characteristics that rendered it more or less desirable.

- The no-action alternative of not constructing the HPFL would have placed the burden of advanced LMFBR fuel development on private industry.

Current Status: $\quad$ For programmatic reasons, certain features of this proposed action were blended into the Process Facility Modifications (PFM) Project (DOE/EIS-0115) when constructed. The HPFL was never built.

ERDA-1556 High-Flux Neutron Source Facility, Hanford Reservation, Richland, Washington, draft, July 1977.

Current Status: This draft was finalized as DOE/EIS-0017; no action resulted. 
HNF-SP-0903, Rev. 7

This page intentionally left blank. 
HNF-SP-0903, Rev. 7

\subsection{U.S. DEPARTMENT OF ENERGY ENVIRONMENTAL IMPACT STATEMENTS}

This chapter provides summaries of EISs.

DOE/EIS-0017 Fusion Materials Irradiation Testing Facility, Hanford Reservation, Richland, Washington, final, April 1978.

Background: This EIS originated as the draft document ERDA-1556(D). This EIS proposed constructing and operating an irradiation test facility, the Deuterium-Lithium High-Flux Neutron Source (HFNS) Facility in the 300 Area of the Hanford Site. This project would have consisted of a test building and an accelerator building with an interconnecting transport tunnel for the deuteron beam.

Test specimens would have been fabricated into irradiation assemblies in existing Hanford Engineering Development Laboratory facilities, and irradiated test specimens transferred to existing Hanford Engineering Development Laboratory facilities for examination.

Alternatives: The alternatives discussed in the EIS included the following.

- The preferred alternative was to construct and operate an irradiation test facility, the HFNS, in the 300 Area of the Hanford Site.

- Alternative designs that were investigated included engineering design features and procedural safeguards to minimize environmental hazards during and after conceivable natural occurrences and accidents, as well as during normal operation.

- Alternative facility locations were examined to determine whether any other sites were preferable to the Hanford Site's 300 Area. A preferable site would have been one that offers the potential for reducing the environmental impact from facility construction and operation. Alternatives included different DOE national laboratories and other locations within the Hanford Site.

- Modification of existing facilities was considered to provide the physical plant equivalent to the Accelerator Building and/or the Test Building. This would have reduced the commitment of resources, thus further reducing the small impact of siting the new building and possibly reducing the cost of the project. Existing facilities in the 300 Area were surveyed for suitability and availability. The 309 Building was identified as a potential candidate to serve as the HFNS Test Building.

ROD: $\quad$ The ROD was never approved.

Current Status: The Fusion Materials Irradiation Testing Facility Project was cancelled. 
DOE/EIS-0046

Background: This EIS proposed a programmatic strategy that emphasized development of conventionally mined waste repositories deep in the earth's geologic formation for disposing commercially generated HLW and TRU waste. Because of the programmatic nature of this document and the preliminary nature of certain design elements assumed in assessing the environmental consequences of the various alternatives, this study was based on generic rather than specific systems.

The main objective of waste disposal was to provide reasonable assurance that this waste, in biologically significant concentrations, would be permanently isolated from the human environment. To provide input to the decision on a planning strategy for disposing of this radioactive waste, this EIS presented an analysis of environmental impacts that could occur if various technologies for management and disposal of such waste was to be developed and implemented.

The DOE was responsible for developing technologies for management and disposal of commercially generated TRU HLWs. The HLW was defined as either the aqueous solution from the first-cycle solvent extraction where spent fuel was reprocessed for recycling of uranium and plutonium or the spent fuel itself if that fuel was to be disposed properly. The HLW also was intensely radioactive. Other waste was generated during reprocessing that, although larger in volume than HLWs, was less intensely radioactive. Waste that contained more than a specified amount of radionuclides of atomic number greater than that of uranium was called TRU waste. Special attention was given to TRU waste because it contained alpha particle-emitting nuclides that were of particular concern as a result of their long half-lives and tenacious retention if incorporated in the body. Other waste forms that included neither HLW or TRU waste were called LLWs.

Alternatives: $\quad$ The alternatives discussed in the EIS included the following:

- Preferred alternative was that the R\&D program for waste management would emphasize the use of mined repositories in geologic formations (in the continental United States) capable of accepting radioactive waste from either the once-through or reprocessing cycles, while continuing to examine subseabed and very-deep-hole disposal as potential backup technologies. This action would be carried forward to identify specific locations for the construction of mined repositories. The proposed action did not preclude further study for other disposal techniques.

- Alternative action was that candidate technologies for parallel development strategy would have been:

- Rock-melt waste disposal

- Island-based geologic disposal

- Ice sheet disposal

- Well injection disposal

- Transmutation concept

- Space disposal

- Placement in the sediment beneath the deep ocean (subseabed)

- Disposal in very deep holes. 
- No-action alternative was that existing spent fuel would be left indefinitely where it was currently stored. Any additional spent fuel discharged from future operation of commercial nuclear power plants would likewise be stored indefinitely in water basin facilities, either at the reactors or at independent sites.

Alternatives: $\quad$ Alternatives considered were:

- Mined repositories

- Parallel technology development

- No-Action alternative.

The decision to proceed with a programmatic strategy favoring the disposal of commercially generated radioactive waste in mined geologic repositories was based on the DOE's commitment to the early and successful solution of the Nation's nuclear waste disposal problem. This would maintain the viability of nuclear energy as a future energy source for the United States. This decision also saved money by focusing federal funds on the further development of the most advanced disposal technique.

ROD:

The ROD was published in the Federal Register, May 14, 1981 (46 FR 26677).

The ROD called for the DOE to select a strategy for the disposal of commercially generated radioactive waste and the supporting program of R\&D. Actions of the ROD included the following:

- Adopt a strategy to develop mined geologic repositories for disposal of commercially generated HLW and TRU radioactive waste, while continuing to examine subseabed and very-deep-hole disposal as potential backup technologies.

- Conduct an R\&D program to develop repositories and the necessary technology to ensure the safe long-term containment and isolation of this waste.

Current Status: The draft version of this document was used on the Hanford Site in the 1970's and 1980 's for the preparation of EAs. At that time, it was known as the Generic/General Hanford Environmental Impact Statement. The document is no longer used for that purpose.

\section{DOE/EIS-0063 Waste Management Operations, Double-Shell Tanks for Defense High-Level Radioactive Waste Storage, Hanford Site, Richland, Washington, final, April 1980.}

Background: $\quad$ This EIS proposed completing the construction and operation of 13 tanks for radioactive liquid HLW storage on an interim basis until long-term or final disposal of the waste could be achieved. This EIS was written as a supplement to ERDA-1538. The scope of the EIS included the examination of design alternatives for the tanks under construction. The new facilities under construction consisted of 133.8 million-liter (1,300,854-gallon) high-activity waste tanks and their auxiliaries. All 13 tanks were being built in the 200 East Area of the Hanford Site. Impacts of 
the various design alternatives considered in this EIS were assessed on the basis of the effects of the designs on tank durability, ease of waste retrieval from such tanks, choices (and timing of such choices) for a long-term radioactive waste storage and final disposal technology, as well as the environment in general.

This EIS did not address the environmental consequences of using the tanks for long-term storage; the plan called for using the tanks only on an interim basis. The design life of the new tank system was considered sufficient to contain the waste pending implementation of long-term disposal.

Alternatives: $\quad$ The alternatives discussed in the EIS were as follows:

- The preferred alternative was to complete construction and use the 13 new DSTs for interim storage of liquid HLW at the Hanford Site. Construction of the tanks was completed and tank use was scheduled to begin in May 1980, after operational testing of all mechanical components and control instruments.

- Use thicker and more chemically resistant steel plates.

- Use an impressed current cathodic protection system to guard the tanks against stress corrosion cracking.

- Use better waste retrieval equipment and enlarged tank openings to facilitate waste removal from tanks at some future date.

- Compare the use of cooling coils to the use of air cooling now provided in the design and construction of the 13 tanks at the Hanford Site.

- The no-action alternative stated that the 13 tanks need not have been constructed and that existing storage tanks would be used as part of the continued present action. The no-action alternative was discussed and shown to be unacceptable.

ROD:

The ROD was published in the Federal Register, July 9, 1980 (45 FR 46155).

The ROD called for construction of the 13 DSTs so they could be used to store defense radioactive HLW at the Hanford Site.

Actions under the ROD included the following:

- The DOE action covered construction and operation of the 13 tanks. The DSTs would be designed to safely contain liquid radioactive waste for an interim period.

- The new DSTs would employ significant design and safety improvements over the 140 SSTs.

Current Status: The DSTs were constructed and are currently in operation. 
DOE/EIS-0080

Background:

Alternatives:
Decommissioning of the Shippingport Atomic Power Station, Hanford Site, Richland, Washington, final, May 1982.

This EIS preferred alternative was to dismantle and remove all fluids, piping, equipment, components, structures, and waste (having radioactivity levels greater than those permitted for unrestricted use) to a waste disposal area. The Hanford Site and Savannah River Site were chosen as possible disposal areas.

The DOE also proposed decommissioning the Shippingport Atomic Power Station near the Ohio River in Shippingport, Pennsylvania. The Shippingport Atomic Power Station was constructed during the mid-1950's as a joint project of the federal government and the Duquesne Light Company to develop and demonstrate pressurized water reactor technology and to generate electricity. The station consisted of a pressurized water reactor, a turbine generator, and associated facilities. The reactor and steam generation portions of the station were owned by the DOE. The electricity-generating portion of the station was owned by the Duquesne Light Company.

The station achieved criticality in December 1957 and had been operated by the Duquesne Light Company under supervision of the DOE Division of Naval Reactors since that time. The station had produced over 6.6 billion kilowatt-hours of electricity. Operation of the station resulted in 37 man-rem of occupational exposure in 1979.

The alternatives in this EIS were as follows:

- The preferred alternative was the immediate dismantling of the Shippingport Atomic Power Station. This included the removal from the site, shortly after shutdown, of all fluids, piping, equipment, components, structures, and waste having radioactivity levels greater than those permitted for unrestricted use. Immediate dismantling resulted in a lower cost than any other decommissioning alternative.

- The safe storage alternative involved dismantling the facility after a storage period of several decades, during which radioactive isotopes would be allowed to decay. During preparation for safe storage, radioactive materials outside the safe storage boundaries would be removed. Security, surveillance, maintenance, and radioactive monitoring would be continued during the safe storage period. Safe storage followed by deferred dismantling would have resulted in higher costs than immediate dismantling and prohibited unrestricted use of the facility and site until deferred dismantling was completed.

- The entombment alternative involved complete isolation of the radioactivity in the station from the environment by means of massive concrete and steel barriers until the radioactivity had decayed to innocuous levels. The pressure vessel cladding and internals might have been removed before entombment or might have been left within the entombed structure, depending on the inventory of radioactivity. Maintenance, surveillance, and occasional monitoring would have been required for this alternative.

- The first no-action alternative involved continuing operation of the station to produce electricity. Because the DOE had no continued use for the station, 
further operation would have required the utility to purchase the station from the federal government and obtain an operation license from the NRC. Because the station was over 20 years old, it was likely that extensive analyses and modifications would have been necessary to meet current NRC requirements.

- The second no-action alternative involved defueling and closing the station, and continuing some monitoring, surveillance, and maintenance of important plant systems. Closing the station while continuing maintenance, monitoring, and surveillance would have left the station intact and would have permitted some decaying of cobalt-60. This would have delayed the decision as to the station's eventual disposition.

- The third no-action alternative involved defueling and closing the station and doing nothing further. This was not an acceptable alternative because the public would have had direct access to radioactive water, equipment, and other material, as well as to high dose rate areas in the station. A substantial effort would have been required to ensure that the radioactivity remaining in the station after defueling constituted no hazard to the public.

ROD: The ROD was published in the FR, August 19, 1982 (47 FR 36276).

The DOE decided to decommission the Shippingport Atomic Power Station. The station would be decommissioned by dismantling immediately following end-of-life testing and defueling of the reactor.

Actions under the ROD included the following.

- Contract No. E(36-1)-292 covered the working relationship between the DOE and the Duquesne Light Company for construction and operation of the Shippingport Atomic Power Station. This contract required that the DOE, on expiration or termination of the contract, "make the nuclear portion of the plant safe from a radiation standpoint."

- All practicable means to avoid or minimize environmental harm from the selected alternatives would be adopted. Plans were developed to keep all radiation exposures ALARA. For example, one-piece removal of the pressure vessel was studied as a way to reduce both occupational radiation dose and cost.

- Workers would wear dosimeters that would need to be checked frequently to ensure compliance with occupational radiation dose guidelines.

- The existing onsite and offsite radiation monitoring program or an equivalent program would be in operation during decommissioning.

- No liquids would be released to the Ohio River unless these met applicable federal and state standards and permit conditions.

- Radioactive waste would be transported according to DOT regulations and would be buried at a DOE disposal site in accordance with criteria established by DOE Order 5480.1A. 
- The volume of radioactive waste from immediate dismantling would have virtually no impact on available DOE disposal space.

- Occupational safety and health practices would be in operation according to the directives of DOE Order 5480.1A and applicable state and federal laws.

Current Status: The Shippingport Atomic Power Station was decommissioned and the reactor vessel was transported to the Hanford Site for disposal.

DOE/EIS-0089 Addendum: Operation of PUREX and Uranium Oxide Plant Facilities, Hanford Site, Richland, Washington, February 1983.

Background: This EIS analyzed the environmental effects of the DOE proposal to resume operation of the PUREX and Uranium Trioxide (UO3) chemical processing facilities. The draft (DOE/EIS-0089) and the addendum make up the Final EIS for the PUREX Facility. The PUREX and UO3 facilities were used to process irradiated fuels and separate plutonium, uranium, and neptunium for use in the DOE's defense and R\&D program. The PUREX and UO3 facilities were used from 1956 to 1972 to process the irradiated fuels produced by up to nine production reactors located on the Hanford Site.

After the PUREX and UO3 facilities processed the inventory of irradiated fuels available in 1972, their continued operation to process fuel produced from the only operating reactor at the Hanford Site was no longer economical. Plans were made to operate the facilities on a batch basis when sufficient quantities of irradiated fuel were available for processing and plutonium was required for defense program and R\&D purposes. Therefore, the PUREX and UO3 facilities have been maintained in standby condition since 1972. During this standby period, modifications have been made to the facilities to mitigate the environmental impact of their operation and to maintain their operational viability. It was determined that processing of the irradiated fuels was required to meet the Nation's defense and R\&D needs.

The PUREX and UO3 facilities consisted of chemical processing facilities used from 1956 to 1972 . Modifications identified in ERDA-1538 have been incorporated into the facilities since 1975 .

These improvements mitigated the environmental impacts and improved safety aspects by: (1) reducing process condensate discharge, (2) improving plant protection measures, and (3) recovering krypton gas.

The radionuclides in the process condensates discharged to the ground through cribs were reduced to less than 50 percent of the 1972 values. Similarly, plutonium contained in liquid effluents discharged to cribs was reduced from about 4 curies per year to an estimated 0.4 curies per year. The radionuclides contained in the ammonia scrubber waste were concentrated by distillation and stored in underground DSTs. The risk of theft or sabotage was reduced by enhanced safeguards for special nuclear materials and improved facility protection measures.

An additional modification considered, but not included in the proposed action, was recovering krypton-85 gas from fuel dissolved offgases before discharge to the environment through the 61-meter (0.0379-cubic yard) stack. The estimated capital 
cost would be $\$ 20$ million for collection equipment, plus about $\$ 150$ million for storage facilities.

Alternatives: The alternatives discussed in the EIS included the following:

- The preferred alternative was the resumption of operation of the Hanford Site PUREX and UO3 facilities to process irradiated N Reactor-equivalent fuel

- Construction of a new fuel processing facility on the Hanford Site

- Processing fuel offsite; however, this would have increased the risk of releases during fuel transport and handling

- No action would have postponed the decision; however, there would be some potential for release during fuel storage.

ROD: $\quad$ The ROD was published in the Federal Register, May 16, 1983 (48 FR 21993).

The DOE decided to resume operation of the PUREX and UO3 chemical processing facilities at the Hanford Site.

Preferred actions in the ROD included the following:

- All releases to the air and groundwater and all population and occupational exposures from operation of the PUREX and UO3 facilities would be below levels established under the DOE standards and guidelines.

- All practicable means to further mitigate environmental impact and safety concerns were to be adopted. In this regard, modifications that were or are being made to the facilities would include the following:

- Gaseous effluent control improvements

- Liquid effluent control improvements

- Upgraded PUREX ventilation system

- Additional security and safeguards procedures and systems for protection of special nuclear materials

- A new criticality alarm system to improve nuclear criticality accident detection and permit more effective mitigative steps

- Upgraded ventilation systems at the UO3 Plant product loadout station

- Upgraded fire protection systems at both the PUREX and UO3 facilities

- New transfer lines to underground storage tanks 
- Seismic protection upgrades

- Plutonium oxide production system within the PUREX Facility.

- The DOE continued to monitor the site with environmental measurement and surveillance programs. An expanded radiological surveillance program initiated in 1979 continued.

Current Status: In 1990, DOE determined that the PUREX Facility would longer operate. The plant is shutdown, deactivated, and readied for D\&D. As of September 1995, an EA approved the transfer of irradiated fuel from the PUREX plant to the K Basins (Reference DOE/EA-0988). The fuel was transferred from the PUREX Plant.

\section{DOE/EIS-0113 Disposal of Hanford Defense High-Level, Transuranic and Tank Waste, Hanford Site, Richland, Washington, final, December 1987.}

Background: This EIS examined the potential impacts calculated for the final disposal of existing high-level TRU and tank waste stored at the Hanford Site since 1943 and future waste. Waste excluded from the scope of this EIS was LLW and waste associated with the D\&D of existing surplus or retired Hanford Site facilities. However, included was the waste from D\&D of future facilities such as the Hanford Waste Vitrification Plant (HWVP) that might be built and operated in direct support of disposal actions addressed in the EIS. While existing and future waste lends themselves to the same type of treatment afforded commercial nuclear waste, the older tanks, cribs, and burial sites contain a variety of waste in forms that could require specialized treatment and recovery.

For purposes of analysis, the waste under the scope of this EIS was divided into six classes; four of these consisted of waste stored or future waste to be placed in interim storage pending disposal, and two classes were waste previously disposed of as LLW. Because of their TRU content, these two were reexamined to determine whether any additional protection was justified.

Existing tank waste, the first waste class, was subdivided further into SSTs and DSTs as a result of the physical and chemical differences in tank contents. The SSTs contain mostly solid waste not readily retrievable. The DSTs contain liquids and suspended solids that are readily retrievable by pumping and sluicing.

Future tank waste, the second waste class, included waste generated from the PUREX Facility's operations after October 1983. This waste was stored in DSTs as liquids and suspended solids that are readily retrievable by pumping and sluicing.

Strontium and cesium capsules, the third waste class, were stored in water basins until disposal. After their useful life, the capsules would be returned for disposal. This waste would be double encapsulated in stainless steel or alloy.

Retrievably stored and newly generated TRU waste, the fourth waste class, contained solid TRU waste produced since 1970 and packaged, labeled, and stored pending final disposal. 
The TRU-contaminated soil sites, the fifth waste class, were sites that contained specific contaminated soil from disposal of liquid waste in cribs, ditches, trenches, settling tanks, French drains, and reverse wells (also known as injection wells). Although previously disposed of, this waste was reexamined to determine whether additional environmental protection was warranted.

Lastly, pre-1970 buried suspect TRU-contaminated solid waste, the sixth waste class, contained general trash and failed equipment buried in trenches before 1970 .

Although previously disposed, this waste also was reexamined to determine whether additional protection was warranted.

Most of the impacts identified would be because of a loss of active institutional control in the year 2150 , which was assumed for all alternatives. These impacts were not representative of continued waste practices.

This EIS was both a programmatic EIS, which was intended to support broad decisions about the disposal strategies for the Hanford Site waste addressed in this EIS, and an implementation EIS intended to provide project-specific environmental input for decisions on certain disposal activities and facilities.

The EIS was prepared before Washington State was granted authority pursuant to the RCRA for mixed waste. The appropriate application of the RCRA and CERCLA to the waste classes in the EIS has not been addressed.

Subsequent to the issuance of the ROD in 1988, the Tri-Party Agreement was signed by the EPA, Ecology, and DOE-RL to implement many of the actions discussed in the ROD, and thus to ensure compliance with the RCRA and CERCLA requirements.

Other laws, standards, and regulations were applicable primarily during operational phases. Operational experience suggests that compliance with these other laws and regulations would not be affected significantly, regardless of the alternatives selected.

Alternatives: The three disposal or enhanced-protection alternatives initially selected for detailed analysis are the following:

- Geologic disposal--Most (98 percent by activity) of the waste within the scope of this EIS would be retrieved (to the extent practicable) and processed, with some packaged and transported for disposal in either an onsite or offsite geologic repository. The remainder would be disposed of onsite and isolated with a protective barrier and marker system.

- In-place stabilization and disposal--The DST waste would be retrieved and grouted in near-surface vaults. The TRU and SST waste would be stabilized in their existing locations to the extent practicable and covered with a protective barrier and marker system. Encapsulated strontium and cesium would be retrieved from water basins, placed in an additional package, placed in a drywell storage facility, and isolated from the environment by a protective barrier and marker system.

- Reference alternative (combination disposal)--Elements of the geologic disposal and in-place stabilization and disposal alternatives would be employed to provide a balanced disposal or enhanced-protection approach that would give 
reasonable expectation that this alternative will limit risks to populations over the long term, without incurring near-term risk because of disturbing waste that is currently stable and difficult to retrieve. Readily retrievable waste would be processed for geologic disposal. Other waste would be disposed of in place. All waste disposed near the surface would be isolated from the environment by a protective barrier and marker system.

A no-action alternative, continued storage of the waste, also was considered in detail. The DOE did not consider this alternative to be a viable long-term option based on current waste management policies, particularly in view of the large accumulated costs associated with maintaining the waste in a storage mode for many centuries. The no-action alternative was analyzed in accordance with the CEQ regulations. In the short term (i.e., for periods less than 100 years), the no-action alternative could be considered as a 'delay major action' alternative, after which time disposal alternatives could be considered. If the DOE were to choose the no-action alternative, waste would remain as disposed of or continue to be stored indefinitely using existing storage practices with planned improvements to comply with the RCRA and CERCLA requirements, as applicable. Active administrative control would be provided. Federal ownership and presence on the Hanford Site was planned in perpetuity (but for comparative analyses, loss of active institutional control was assumed to occur in the year 2150). It must be emphasized that this scenario was defined simply for comparing alternatives. Present disposal practices with active administrative control will not result in the impacts calculated for this scenario.

The preferred alternative was developed following agency and public review of the draft EIS and consists of a combination of the reference alternative for some classes of waste and a deferred decision for other classes of waste. Under this alternative, readily retrievable waste (DST waste, strontium and cesium capsules, and retrievably stored and newly generated TRU waste) would be processed for geologic and grout disposal, and other waste would be left in place until results of ongoing or planned development and evaluation are obtained.

ROD: $\quad$ The ROD was published in the Federal Register, April 14, 1988 (53 FR 12449). It was decided to implement the 'preferred alternative' as discussed in DOE/EIS-0113. Actions under the ROD were as follows:

- To proceed with the disposal activities for the following defense waste at the Hanford Site:

- DST waste

- Retrievably stored and newly generated TRU waste

- The only pre-1970 buried suspect TRU-contaminated solid waste site outside the 200 Areas Plateau

- Strontium and cesium encapsulated waste.

- To process existing and future waste from the storage DSTs at the Hanford Site for final disposal, the DOE would design, construct, and operate the HWVP; complete the necessary pretreatment modifications and operate the pretreatment 
facility (planned to be the Hanford B Plant); and use the Hanford Site Transportable Grout Facility

- The radioactive HLW fraction would be processed into a borosilicate glass waste form and stored at the HWVP until a geologic fraction would be solidified as a cement-based grout and disposed at the Hanford Site in near-surface, concrete-lined vaults

- Existing and future DST waste would be characterized for hazardous chemical constituents, as well as other chemical constituents that could affect glass or grout formulation, before processing

- The Waste Receiving and Processing Facility would be designed, constructed, and operated at the Hanford Site to sort, process, and repackage retrievably stored and newly generated TRU-contaminated solid waste for shipment to the WIPP located approximately 41.84 kilometers ( 26 miles) from Carlsbad, New Mexico. The only pre- 1970 buried suspect TRU-contaminated solid waste site outside the Central Plateau would be removed to the 200 Areas Plateau for disposal as solid TRU waste

- Encapsulated cesium and strontium waste would continue to be stored safely until a geologic repository was ready to receive this waste for disposal. Before shipment to a geologic repository, this waste would be packaged in accordance with repository waste acceptance specifications

- For the remainder of the waste classes covered in the Hanford Defense Waste-EIS (DOE 1987) (SST waste, TRU-contaminated soil sites, and pre-1970 buried TRU-contaminated solid waste within the 200 Areas Plateau), the DOE had decided to conduct additional development and evaluation before making decisions on final disposal. This development and evaluation would focus on methods to retrieve and process this waste for disposal, as well as methods for stabilizing and isolating the waste stored near surface. Results from this work. would be publicly available. Before decisions on final disposal of this waste, the alternatives would be analyzed in subsequent environmental documentation, including a supplement to the Hanford Defense Waste-EIS (DOE 1987) for decisions on disposal of the SST waste

- There was one exception to waiting for the final disposal of SST waste, TRU-contaminated soil sites, and pre- 1970 buried suspect soil sites. The exception was that to consolidate the waste, the DOE would proceed with exhuming and processing the only pre- 1970 buried TRU-contaminated solid waste site (the 618-11 site) located outside the 200 Areas Plateau

- For the pre-1970 buried TRU-contaminated solid waste and TRU-contaminated soil sites (except for the 618-11 site), the present remedial action program would continue. 
Current Status: There have been three Supplement Analyses approved to support this EIS as follows:

- Canister Storage Building (CSB) Foundation and Support Building (2704HV).

- WRAP I

- WRAP IIA

The Supplement Analysis (SA) for the CSB was approved to construct the facility for storage of high-level borosilicate log canisters. However, other NEPA decisions identified additional programmatic uses for the CSB (e.g., storage of high-level glass log canisters; low-level glass log canisters; WESF capsules; and K Basin spent nuclear fuel).

A SA was prepared and approved to cover the construction and operation of the Waste Receiving and Processing Facility, Module 1 (Module 1). Module 1 would examine, process, repackage, and certify certain CH-TRU waste for shipment to WIPP that meets certain size and weight criteria. In December, 1992, a DOE decision was reached that the impacts of construction and operation of WRAP 1 were covered adequately in the HDW-EIS.

An SA also was prepared for WRAP 2A and a determination made that impacts of construction and operation were covered adequately in the HDW-EIS. The primary purpose of the WRAP 2A would be to handle $\mathrm{CH}$-TRU mixed waste.

\section{DOE/EIS-0115 Process Facility Modifications Project, Hanford Site, Richland, Washington, draft canceled April 1986.}

Background: This EIS proposed constructing and operating a segmentation and dissolution facility as a front-end modification to the PUREX Facility at the Hanford Site. The PFMs would permit the recovery of plutonium from the irradiated FFTF fuel for use in DOE programs. The FFTF fuel would have been prepared in the PFM for subsequent processing in the PUREX Facility. A corollary purpose was to provide an improved method of preparing irradiated fuel from the DOE's $N$ Reactor (N-fuel) for processing in the PUREX Facility.

The proposed action also would have eliminated the current method of chemically decladding irradiated $\mathrm{N}$-fuel, thereby reducing the volume of radioactive liquid waste and the potential environmental impacts of waste management at the Hanford Site. The PFM would not have been a standalone facility that produced a final end product; its function would have been to segment the fuel elements into short pieces from which the fuel could be dissolved. The dissolved fuel solution would have been transferred to the PUREX Facility for separation and purification of the plutonium, uranium, and desired byproducts.

The proposed PFM capabilities would have included cask handling, fuel storage, fue! segmentation and dissolution, and handling of offgas and solid waste. Construction would have started in 1986. The PFM would have been operational in 1993. The EIS included discussion of the PFM facility and processes; quantities, composition, and disposition of process waste; the relationship of the PFM to the PUREX and UO3 Facility operations and other facilities; and analysis of projected environmental impacts. 
Alternatives: The alternatives discussed in this EIS were as follows:

- Preferred alternative: Construct and operate the PFM as a front end modification to the PUREX Facility

- To construct and operate a smaller scale segmentation and dissolution facility adjacent to the Hanford Site PUREX Facility to process the FFTF fuel. During normal operations, the smaller scale PFM would have released gaseous and particulate emissions and solid waste. Radioactive liquid waste would have been routed to the PUREX Facility for treatment before disposal

- To transport and process the FFTF fuel at the DOE Savannah River Site by providing modifications at the Savannah River Site to process the FFTF fuel. Although the quantities of radionuclides released would have been similar to the Hanford Site and Savannah River Site, the integrated 70-year whole body dose to an offsite individual of the population would have been higher at the Savannah River Site than at the Hanford Site. This higher dose would have occurred because the Savannah River Site population was larger and closer to the site, and the pathways for radionuclides in liquid effluents to reach the population were more direct

- To modify existing structures at the Hanford Site to process the FFTF fuel only. Processing, whether performed at the FMEF or at the PUREX Facility as modified by the PFM, would have required the same essential unit operations, and the environmental consequences would have been similar, except for higher radiation doses resulting from closer proximity of the population to the site

- The no-action alternative would not have resulted in significantly different environmental effects from the proposed action or the alternatives, except that it lacked the benefits of reduced HLW and cladding removal waste.

Each of the alternatives to the proposed action would have continued to process $\mathrm{N}$-fuel in the existing Hanford Site PUREX Facility, using the then-current operating chemical decladding process. The DOE's preferred alternative was the proposed action; only this action would have reduced the radioactive liquid waste volumes requiring storage in underground DSTs, while also recovering the plutonium from the FFTF fuel needed to satisfy national defense and R\&D purposes.

Current Status: This draft was not finalized. This project was cancelled.

DOE/EIS-0119 Decommissioning of Eight Surplus Production Reactors at the Hanford Site, Richland, Washington, final, December 1992.

Background: $\quad$ This EIS provided environmental information to assist the DOE in the selection of a decommissioning alternative for the eight surplus production reactors at the Hanford Site (54 FR 18325). Nine water-cooled, graphite-moderated plutonium production reactors were constructed along the Columbia River at the Hanford Site between 1943 and 1963. Eight of these reactors (B, C, D, DR, F, H, KE, and KW) were retired from service and were available for decommissioning. 
In 1980, the DOE approved an EA of the F Area Decommissioning Program, which addressed dismantling the $F$ Reactor and disposal of radioactive materials in burial grounds in the 200 Areas of the Hanford Site. Four alternatives were considered at that time: layaway, protective storage, entombment, and dismantling. Based on the EA, a FONSI for the dismantling alternative was published in the FR, August 22, 1980 (45 FR 56125).

The DOE then noted that it would be more appropriate to consider and implement a consolidated decommissioning program for all eight of the surplus production reactors at the Hanford Site, and decided to examine all reasonable decommissioning alternatives. Accordingly, on May 16, 1985, the DOE published a "Notice of Intent to Prepare an Environmental Impact Statement on Decommissioning the Eight Shutdown Production Reactors Located at the Hanford Site, Near Richland, Washington" in the 50 FR 20489. The scope of the draft EIS included only the disposition of the eight reactors, fuel storage basins, and the buildings housing these systems. To comply with the NEPA requirement for early preparation of environmental documentation, this draft EIS had been prepared before final engineering plans for decommissioning the reactors were available. As with any major action, it was expected that once a decommissioning alternative was selected, detailed engineering design would be carried out that could improve on the conceptual engineering plans presented. However, the engineering design would result in environmental impacts not significantly greater than those described here.

Alternatives: The alternatives discussed in this EIS were as follows.

- The preferred alternative was to demolish the reactor buildings and transport the reactor blocks in one piece by tractor-transport across the Hanford Site along a predetermined route to an onsite LLW burial area.

- The reactors would be stored temporarily in secure status for 75 years, after which the reactor buildings would be demolished and the reactor blocks transported in one piece by tractor-transport across the Hanford Site along a predetermined route to an onsite LLW burial area.

- The reactors would be stored temporarily in a safe, secure status for 75 years, after which the reactors would be dismantled fully and any remaining radioactive waste would be transported to an LLW burial area on the Hanford Site.

- The reactors would remain at their present locations; contamination would be contained; major voids would be filled; potential pathways would be sealed; and an engineered mound of building rubble, earth, and gravel would be constructed over the decommissioned reactor to provide a long-term protective barrier against human intrusion, water infiltration, and water and wind erosion.

- The no-action alternative was that the reactors be left in place and the present maintenance and surveillance programs continue.

- Close the facilities and do nothing further. This alternative was neither responsible nor acceptable and was not considered further. 
Current Status: The ROD was published in 58 FR 48509 (September 1993). The DOE decided in favor of the preferred alternative; the reactor blocks for the Hanford Site's eight defunct plutonium reactors will be kept at their present sites until their radiation level lowers through natural decay and will be buried. The DOE hopes to begin moving the reactor blocks without dismantling to the burial site on the Hanford Site's Central Plateau in approximately 75 years. The B Reactor has since been included in the National Register of Historic Places and will likely remain in place and intact.

\section{DOE/EIS-0189 Tank Waste Remediation System,} Hanford Site, Richland, Washington

Background: The 200 Areas of the Central Plateau, where the waste tanks and cesium and strontium capsules are located, have been used extensively for fuel reprocessing, waste management, and disposal activities. In addition to the waste tanks and capsules, the 200 Areas are the location of several inactive fuel reprocessing facilities (REDOX, PUREX, T Plant, B Plant, U Plant, and PFP), buried solid waste, and irradiated fuel storage. The 200 Areas are also the location of 43 of the 72 Superfund sites (past waste disposal or release sites requiring investigation and potential remediation), nearly 2,500 hectares (6,200 acres) of surface contamination, and past contaminant releases to the ground, which have resulted in groundwater contamination plumes that underlie approximately 520 square kilometers ( 200 square miles) of the Hanford Site.

More than 80 percent ( 391 million curies) of the radionuclides are estimated to be located in the 200 Areas. Of the radionuclides in the 200 Areas, the waste in the tanks (208.5 million curies) and the cesium and strontium capsules (173.5 million curies) account for approximately 97 percent of the inventory. Another 1.4 million curies are estimated to have been released or leaked to the ground, approximately 4.9 million curies have been disposed of in solid waste burial grounds, and 2.6 million curies are stored in solids or contained in irradiated fuel storage. The TWRS EIS addresses only management and disposal of tank waste and the cesium and strontium capsules.

The alternatives that were in the draft EIS were as follows:

- No Action Alternative (Tank Waste)

- Continue current waste management activities

- No remediation performed

- Long-Term Management Alternative

- Continue Current waste management activities

- Similar to No Action, except includes replacing DSTs in 40 years and again in 90 years

- Includes upgrades to tank farm system to address safety and regulatory compliance issues

- No remediation performed 
- In Situ Fill and Cap Altemative

- Remove and treat liquid

- Fill tanks with gravel (no waste immobilization)

- Cover tanks with Hanford Barriers

- All waste disposed of onsite

- In Situ Vitrification Alternative

- Remove and treat liquid

- Vitrify waste in-place

- All waste immobilized and disposed of onsite

- Ex Situ Intermediate Separations Alternative

- Retrieve maximum amount of waste practicable

- Separate waste into LLW and HLW using sludge washing and ion exchange

- Vitrify waste

- Dispose of LLW onsite in subsurface vaults

- Dispose of HLW offsite at the potential geologic repository

- Ex Situ No Separations (vitrification or calcination) Alternative

- Retrieve maximum amount of waste practicable

- Vitrify or calcine waste

- Dispose of all waste offsite at the potential geologic repository

- Ex Situ Extensive Separations Alternative

- Retrieve maximum amount of waste practicable

- Separate waste into LLW and HLW using multiple separation process

- Vitrify waste

- Dispose of LLW onsite in subsurface vaults

- Dispose of HLW offsite at the potential geologic repository

- Ex Situ/In Situ Combination Alternative

- Retrieve approximately 50 percent of the waste volume based on long-term risk

- Fill remaining tanks with gravel and cover with Hanford Barriers

- Separate retrieved waste into LLW and HLW using sludge washing and ion exchange

- Vitrify all waste retrieved

- Dispose of LLW onsite in subsurface vaults

- Dispose of HLW offsite at the potential geologic repository

- Phased Implementation Alternative

- Construct and operate two demonstration-scale facilities to prove the concept for immobilization is effective before building a full-scale facility 
- Perform retrieval, separations, immobilization, and disposal similar to the Ex Situ Intermediate Separations alternative

- No Action (Capsules)

- Continue safe storage in WESF

- No remediation would be performed

- Onsite Disposal Alternative

- Retrieve capsules from WESF and package for disposal

- Dispose of in shallow subsurface dry wells

- All capsules would be disposed of onsite

- Overpack and Ship Alternative

- Retrieve capsules from WESF and package for offsite shipment

- Ship capsules to the potential geologic repository for disposal

- Vitrify with Tank Waste Alternative

- Retrieve capsules from WESF and transport to tank waste vitrification facility

- Vitrify capsule contents with high-level tank waste

- Ship to potential geologic repository for disposal with tank waste

ROD:

The ROD was issued February 27, 1997. In the ROD, DOE decided to implement the preferred alternative identified in the Final EIS for retrieval, treatment, and disposal of tank waste, the "Phased Implementation alternative" and to defer the decision on disposition of cesium and strontium capsules.

Supplement Analysis: Supplement Analysis for the Proposed Upgrades to the Tank Farm Ventilation, Instrumentation, and Electrical Systems under Project W-314 in Support of Tank Farm Restoration and Safe Operations (DOE/EIS-0189-SA1) - This SA was prepared to support a determination on the need for additional NEPA analysis regarding Tank Farm upgrades in the areas of instrumentation and control, tank ventilation, waste transfer, and electrical distribution for existing Tank Farms [i.e., Project W-314 (which was included in the TWRS EIS analysis)]. Based on the SA, DOE determined that no additional NEPA analysis was required. The SA was signed June 6, 1997.

Supplement Analysis: Supplement Analysis for the Tank Waste Remediation System (DOE/EIS-0189-SA2) - This SA was prepared to support a determination on the need for additional NEPA analysis regarding those areas of Tank Waste Remediation System (TWRS) activities where new data and information has become available. Sources of substantive new information include: revised tank waste inventory; new accident analysis documentation; emerging vadose zone transport data and analysis; revised engineering parameters; and technology development activities. Based on the SA, DOE determined that no additional NEPA analysis was required. The SA was signed May 15, 1998.

Current Status: Tank waste disposition alternatives are being implemented. 
HNF-SP-0903, Rev. 7

DOE/EIS-0200 Office of Environmental Management Programmatic Environmental Impact Statement (PEIS)

Background: $\quad$ This Waste Management Programmatic Environmental Impact Statement (WM PEIS) is a nationwide study. The study examines the environmental impacts of managing five types of radioactive and hazardous waste that results primarily from nuclear defense activities - the development, production, and testing of nuclear weapons at a variety of sites located around the United States. The five waste types are as follows:

- Low-Level Mixed (LLM)

- Low-Level (LL)

- Transuranic (TRU)

- High-Level (HL)

- Hazardous (HW).

The DOE intends to enhance the management of its current and anticipated volumes of LLM, LL, TRU, HL, and HW to ensure safe and efficient management of these waste types. Each waste type has unique physical and regulatory requirements and accordingly is managed separately. For each waste type system, facilities are needed to treat, store, and dispose of the waste. This EIS not only examines the waste in an integrated fashion for the impacts of complex-wide waste management decisions for each waste type but also the specific cumulative impacts for all the waste facilities at a given site. In this context, management of these waste types includes the following:

- Modifying existing waste management facilities or constructing new facilities or constructing new facilities at particular sites

- Operating modified or new waste management facilities at those sites

- Transporting waste among waste management facilities, as necessary

- Sampling and analyzing waste constituents, as necessary.

Alternatives: There are four categories of alternatives.

- No Action: Selection of this alternative would involve using only currently existing or planned waste management facilities at DOE sites. This alternative provides an environmental baseline against which the impacts of other alternatives can be compared.

- Decentralized Alternatives: Selection of these alternatives would result in managing waste where it is or where it would be generated, treated, or disposed in the future. Under these alternatives, the waste management facilities would be located at a larger number of sites than under the regionalized or centralized alternatives. 
- Regionalized Alternatives: Selection of these alternatives would result in transporting wastes to various sites (fewer than the number of sites considered for the decentralized alternatives but greater than the number of sites considered for the centralized alternatives). More than one regionalized alternative is considered for all waste types.

- Centralized Alternatives: Selection of these alternatives would result in transporting waste to one or two sites for treatment, storage, or disposal. As with the regionalized alternatives, those sites that have the largest volumes of a given waste type generally were considered as sites for centralized treatment, storage, or disposal.

Current Status: The Notice of Availability for the draft EIS was published in the Federal Register on September 22, 1995. The final EIS was issued in May 1997. The TRU Treatment ROD was approved on January 20,1998 and was published in the Federal Register on January 23, 1998 (63 FR 3629). The Hazardous Waste Treatment ROD was published in the FR on August 5, 1998 (63 FR 41810). The HLW Storage ROD was published on August 26, 1999 (64 FR 46661). The Treatment and Disposal of Low-Level Waste and Mixed Low-Level Waste ROD was issued on February 18, 2000 (65 FR 10061).

\section{DOE/EIS-0203 Programmatic Spent Nuclear Fuel Management and Idaho National Engineering} Laboratory Environmental Restoration and Waste Management Programs, final.

Background: This EIS considered the programmatic (DOE-wide) alternative approaches to safely, efficiently, and responsibly manage existing and projected quantities of spent nuclear fuel until the year 2035. The DOE's spent nuclear fuel responsibilities include fuel generated by DOE production, research, and development reactors; naval reactors; domestic non-DOE reactors such as those at the National Institute of Standards and Technology and the Armed Forces Radiobiology Research Institute; and special-case commercial reactors such as Fort St. Vrain and the Lynchburg Technology Center.

The DOE did not analyze the ultimate disposition (final step in which material is disposed) of spent nuclear fuel in this EIS. Decisions regarding the actual disposition of DOE's spent nuclear fuel will follow appropriate review under the NEPA and be subject to licensing by the NRC.

Alternatives: $\quad$ The DOE must provide for safe, efficient management of its spent nuclear fuel during the next 40 years, pending ultimate disposition. The alternatives considered are as follows.

- No Action: Take minimum actions required for safe and secure management of spent nuclear fuel at or close to the generation site or current storage location.

- Decentralization: Store most spent nuclear fuel at or close to the generation site or current storage location with limited shipments to DOE facilities.

- 1992/1993 Planning Basis: Transport to and store newly generated spent nuclear fuel at the Idaho National Engineering Laboratory or Savannah River Site. Consolidate some existing fuels at the Idaho National Engineering Laboratory or the Savannah River Site. 
- Regionalization: Distribute existing and projected spent nuclear fuel among DOE sites based primarily of fuel type or geography.

- Centralization: Manage all existing and projected spent nuclear fuel inventories from DOE and the Navy at one site until ultimate disposition.

ROD: $\quad$ The ROD was issued June 1, 1995 (60 FR 28680).

The ROD includes a Department-wide decision to regionalize spent nuclear fuel management by fuel type for Department-owned spent nuclear fuel. The ROD also contains decisions dealing with site-wide environmental restoration and waste management programs at the Idaho National Engineering Laboratory.

Spent Nuclear Fuel Management. The DOE has decided to regionalize spent nuclear fuel management by fuel type at three sites: Hanford Site, Idaho National Engineering Laboratory, and Savannah River. Under this decision, the fuel type distribution would be as follows.

- Hanford production reactor fuel will remain on the Hanford Site.

- Aluminum clad fuel will be consolidated at the Savannah River Site.

- Non-aluminum clad fuels (including spent nuclear fuel from the Fort St. Vrain Reactor and Naval spent fuel) will be transferred to the Idaho National Engineering Laboratory.

The Navy will resume shipments of its spent nuclear fuel to the Idaho National Engineering Laboratory immediately, upon the staying or dissolution of an injunction ordered by the United States District Court for the District of Idaho on May 19, 1995.

\section{Amendment to Record of Decision.}

The Department of Energy (DOE) has issued an amendment (61 FR 9441) to the May 30, 1995 Record of Decision on the Programmatic Spent Nuclear Fuel Management and Idaho National Engineering Laboratory Environmental Restoration and Waste Management Programs Final Environmental Impact Statement (60 FR 28680). The May 30, 1995 Record of Decision includes a decision to regionalize the management of DOE owned spent nuclear fuel, by fuel type, and also includes decisions concerning environmental restoration and waste management programs at the Idaho National Engineering Laboratory. The amended Record of Decision reflects the October 16, 1995 Settlement Agreement among DOE, the State of Idaho, and the Department of the Navy pertaining to spent nuclear fuel shipments into and out of the State of Idaho. The Settlement Agreement was entered as a Consent Order by the U.S. District Court for the District of Idaho on October 17, 1995, which resolved litigation between the State of Idaho and DOE. This amended Record of Decision does not modify or rescind any of the provisions of the May 30, 1995 Record of Decision, except as follows:

The amended Record of Decision reduces the number of shipments of spent nuclear fuel into the State of Idaho. As a result, there are differences in the number of spent nuclear fuel shipments and inventories from those listed in Tables 3.1 and 3.2 of the 
May 30, 1995 Record of Decision. Tables 1.1 and 1.2 of this amendment hereby revise Tables 3.1 and 3.2, respectively, of the May 30, 1995 Record of Decision to show those differences. Table 1.1 shows the origin and interim management destination of specific fuels and the potential number of shipments. One shipment, whether by truck or rail, consists of a single shipping container of spent nuclear fuel. Table 1.2 shows the existing and resulting inventory at DOE's main spent nuclear fuel management locations. The differences include the Fort St. Vrain fuel and 512 shipments of the Hanford Site fuel. The change regarding Fort St. Vrain spent nuclear fuel shipments implements an explicit provision of the October 17, 1995 Consent Order settling the litigation among the State of Idaho, the Department of Energy, and the Department of the Navy. The change regarding spent nuclear fuel at the Hanford site reflects the Consent Order's general limitation of spent nuclear fuel shipments to the Idaho National Engineering Laboratory. Both the Fort St. Vrain and Hanford spent fuels may be safely maintained at their present locations. There are also refinements in the number of spent nuclear fuel shipments to the Idaho National Engineering Laboratory from Argonne National Laboratory-East, Sandia National Laboratory, the Oak Ridge Reservation, Babcock \& Wilcox, and Foreign Research Reactors. The environmental impacts associated with the decisions contained in this Amendment were analyzed in the DOE Programmatic Spent Nuclear Fuel Management and Idaho National Engineering Laboratory Environmental Restoration and Waste Management Programs Final Environmental Impact Statement.

Current Status: Activities described in the ROD have been, and are being, implemented.

DOE/EIS-0212 Safe Interim Storage of Hanford Tank Wastes, Hanford Site, Richland, Washington, final.

Background: The DOE proposed to prepare the Safe Interim Storage (SIS)-EIS in response to the need, identified by the DOE and Ecology, to address near-term safety issues in the Hanford Site priority Watchlist tanks. The SIS-EIS would respond to the need to allow for continued safe operation of facilities that generate waste on the Hanford Site to comply with existing regulations. Safety concerns regarding Watchlist tanks have been identified as the Priority 1 Hanford Site Tank Farm Safety Issues (issues/situations that contain the most necessary conditions that could lead to worker or offsite radiation exposure through an uncontrolled release of fission products). The SIS-EIS considers alternatives for maintaining safe interim storage of Hanford Site tank waste types during the interim period before making and implementing decisions that would be the subject of analysis in the TWRS EIS.

Processing of reactor fuel for plutonium production and other waste management activities created a wide variety of radioactive and hazardous waste, some of which have been stored in underground tanks. The radioactive wastes from various processes have been transferred among tanks so that chemical and physical characteristics of the waste types vary greatly among tanks and even within individual tanks. Typically, tank waste is highly radioactive and chemically hazardous.

On November 5, 1990, the U.S. Congress enacted Public Law 101-510, Safety Measures for Waste Tanks at Hanford Nuclear Reservation, of the National Defense Authorization Act for Fiscal 1991, which addresses safety issues concerning the handling of waste in Hanford Site tanks. In response to this legislation, DOE created 
the tank Watchlist that identified those tanks with potential safety concerns that warranted special attention. Safety issues have been prioritized by the DOE high-level Waste Tank Task Force.

The DOE and Ecology have determined that the accumulation of high concentrations of flammable gas, principally hydrogen, occurring in 101-SY tank constituted a safety problem of the highest priority. The mitigation of hydrogen production, pressure generation, and unacceptably high concentrations of flammable gas in this tank is a primary focus of the actions evaluated in this EIS. Additionally, the actions considered include alternative methods of waste transfer across the Hanford Site, either in support of mitigating the safety issues.

Alternatives: The preferred alternative consisted of the following components:

- Construction and operation of the Replacement Cross-Site Transfer System (RCSTS) for cross-site transfer of SWLs, and 200 West Area Facility waste from 102-SY tank to DSTs in the 200 East Area

- Construction of a waste retrieval system in 102-SY tank to retrieve solids

- Continued operation of a mixer pump in 101-SY tank

- Transfer of liquid waste through the Existing Cross-Site Transfer System (ECSTS) until the proposed RCSTS becomes operational in 1998.

ROD:

The ROD was issued by the DOE on November 21, 1995 (60 FR 61687).

Basis for the ROD Decision: Based on the consideration of environmental impacts, cost, engineering standards, criticality safety, and comments received on the Final SIS EIS will process with the preferred alternatives.

ROD Decision: The DOE will construct and operate the RCSTS on the proposed route identified in the Final SIS EIS, continue operating the mixer pump in 101-SY tank, and transfer waste from the interim stabilization program and other facility waste in the 200 West Area. During construction of the RCSTS, SWLs and 200 West Area facility waste will be transferred through the ECSTS to DST storage in the 200 East Area. These actions will provide safe, compliant, and reliable high-level waste transfer capabilities and will operate with waste at subcritical levels under the existing Hanford Tank Farm Interim Safety Basis, until final disposal decisions are made under the TWRS EIS.

Current Status: Activities described in the ROD have been, and are being, implemented. Those activities include installation and operation of a cross-site transfer line for tank waste, and ongoing tank waste maintenance and operations.

\section{DOE/EIS-0222 \\ Hanford Comprehensive Land-Use Plan Environmental Impact Statement}

Background:

This EIS would be used to develop a coordinated strategy for remediation of hazardous and radioactive waste sites on the Hanford Site. This strategy would integrate potential future Hanford Site land uses into remediation decisions. Adoption of this coordinated strategy would ensure that remediation goals for the 
Hanford Site are coordinated both with DOE's requirements for land and other resources needed for the remediation project and with the Hanford Site's other missions while protecting human health and the environment. Coordinating remediation goals for each geographic area of the Hanford Site into a coherent remediation strategy for the entire Hanford Site would minimize the likelihood of making inconsistent decisions at the operable unit level.

Alternatives: $\quad$ This EIS will analyze a No Action Alternative and a range of alternatives reflecting reasonable remediation strategies for the Hanford Site. The Hanford Site has been divided into four geographic areas for the purpose of analyzing impacts:

- Columbia River

- Reactors on the Columbia River

- Central Plateau

- All other areas.

The remediation strategies for these geographic areas are based on three broad categories of levels of access that would be consistent with the nature and extent of any residual contamination remaining following remediation - unrestricted, restricted, and exclusive. These use categories serve as remediation goals representing the aggregate condition of each geographic area. Although portions of the Hanford Site are uncontaminated, the future uses of each geographic area would be determined by the amount of remediation that can be achieved at the waste sites rather than by the condition of the uncontaminated areas.

The Hanford Site has two additional geographic areas - the Fitzner/Eberhardt Arid Lands Ecology Reserve and north of the River. The waste sites in the Fitzner/Eberhardt Arid Lands Ecology Reserve and north of the River already have been remediated and, therefore, are not addressed in the EIS.

The EIS will not select or recommend specific remediation technologies because decisions to deploy specific technologies would be made via the CERCLA/RCRA past-practice regulatory process.

ROD: $\quad$ The ROD was published in the Federal Register (64 FR 61615) on November 12, 1999. The land-use plan consists of several key elements that are included in the preferred alternative in the FEIS.

Current Status: Activities described in the ROD are being implemented.

DOE/EIS-0229

Background:

\section{Storage and Disposition of Weapons Usable Fissile Materials final.}

This programmatic EIS, among other things, assesses the potential environmental impacts of alternatives and locations for storing weapons-usable fissile materials (plutonium and highly-enriched uranium.

On January 14, 1997, DOE issued a ROD (62 FR 3014; January 21, 1997) selecting weapons-usable fissile materials storage and surplus plutonium disposition strategies. For plutonium storage, DOE decided to consolidate part of its weapons-usable plutonium storage by upgrading and expanding existing and planned facilities at the Pantex Plant near Amarillo, Texas and the Savannah River Site (SRS) near Aiken, 
South Carolina. For plutonium currently stored at the Hanford Site (Hanford) near Richland, Washington, and other DOE sites, DOE decided that surplus weapons-usable plutonium would remain at these sites until disposition (or move to lag storage at a disposition facility). The plutonium destined for the SRS, i.e., non-pit, weapons-usable surplus plutonium, would be moved only if certain conditions were met. Those conditions were: (1) the plutonium had been stabilized under corrective actions in response to the Defense Nuclear Facilities Safety Board (DNFSB) Recommendation 94-1 and packaged to meet the DOE storage Standard 3013-96, Criteria for Safe Storage of Plutonium Metals and Oxides, (2) the construction and expansion of the Actinide Packaging and Storage Facility (APSF) at the SRS had been completed, and (3) the SRS had been selected in the upcoming Record of Decision for the Surplus Plutonium Disposition Environmental Impact Statement as the immobilization disposition site for surplus weapons-usable plutonium.

On August 6, 1998, DOE issued an amended ROD (63 FR 43386) to support, in part, early deactivation of plutonium storage facilities at the Hanford Site. Namely, DOE will take steps that allow the relocation of all Hanford surplus weapons-usable plutonium (about 4.6 metric tons) to the SRS, between about 2002 and 2005 , pending disposition. However, consistent with the storage and Disposition PEIS ROD, DOE will only implement the movement of Hanford non-pit, surplus weapons-usable plutonium inventories to the SRS if the SRS is selected as the immobilization disposition site. All shipments of plutonium to SRS will be by Safe Secure Transport (SST) in accordance with applicable DOE, U.S. Department of Transportation and U.S. Nuclear Regulatory Commission requirements and regulations.

Current Status: DOE is pursuing implementation of activities described in the ROD.

DOE/EIS-0244 Plutonium Finishing Plant, 200 West Area, Hanford Site, Richland, Washington, final.

Background: The EIS evaluates the potential impacts associated with the stabilization of plutonium-bearing materials at the PFP. These materials have been grouped into four categories:

- Nitrate and chloride solutions (ion exchange, vertical calcination, and thermal stabilization)

- Oxides, fluorides, and process residues (thermal stabilization using a continuous furnace)

- Metals and alloys (repackaging)

- Polycubes and combustibles.

Alternatives: $\quad$ The preferred alternative involves removing and stabilizing plutonium-bearing material currently in hold-up at the PFP Facility. This is material that has accumulated or been retained in PFP Facility gloveboxes, hoods, process equipment, piping, exhaust and ventilation systems, and the PRF canyon as a result of 40 years of plutonium processing operations. The removal activities would be limited to materials that are readily retrievable. Because of the nature and location of the 
material in hold-up, various technologies would be employed to remove the material for subsequent stabilization.

ROD: $\quad$ The Final EIS (FEIS) was approved by DOE-RL on May 10, 1996. The ROD was published in the Federal Register on July 10, 1996 (61 FR 36352).

Basis for the ROD Decision: Based on the consideration of environmental impacts, cost, engineering standards, criticality safety, and comments received on the Final PFP EIS, DOE will implement a select group of stabilization alternatives.

ROD Decision: The DOE will implement a select group of stabilization alternatives identified in the Final EIS. These include three out of four of the preferred stabilization and immobilization processes analyzed in the Final EIS. The action also will involve the removal of readily retrievable plutonium-bearing material in hold-up at the PFP Facility and the stabilization of this and other plutonium-bearing material at the PFP Facility. Following stabilization, plutonium-bearing material will be in a form suitable for interim storage in existing vaults at the PFP Facility.

Plutonium-bearing material having low plutonium content and meeting criteria established by DOE may be immobilized through a cementation process at the PFP Facility and transferred to a Hanford Site solid waste management facility for storage. By selecting a suite of alternatives, DOE anticipates that health impacts to workers and the cost to implement the action will be reduced.

The primary stabilization processes for each inventory are as follows:

- Plutonium-bearing solutions (ion exchange, vertical calcination, and thermal stabilization; and hydroxide precipitation followed by thermal stabilization)

- Oxides, fluoride, and process residues (batch thermal stabilization using muffle furnaces)

- Metals and alloys (batch thermal stabilization using muffle furnaces)

- Polycubes and combustibles [pyrolysis (a thermal process involving distillation and decarbonization that separates the plutonium oxides from the polystyrene) and batch thermal stabilization]

- Removal of holdup (limited to plutonium-bearing materials that readily are retrievable)

- Immobilization (candidate plutonium-bearing material with low plutonium content may be immobilized and discarded. The plutonium-bearing material will include materials that are containerized and stored in vaults or gloveboxes and hold-up material).

Supplement Analysis: Supplement Analysis for the Immobilization of Plutonium-Bearing Materials at the Plutonium Finishing Plant, Hanford Site, Richland, Washington (DOE/EIS-0244-FS/SA1) - This SA was prepared to support a determination on the need for additional NEPA analysis regarding packaging concreted plutonium-bearing materials at PFP. Based on the SA, DOE determined that no additional NEPA analysis was required. The SA was signed March 28, 1997. 
Supplement Analysis: Supplement Analysis, Increasing Batch Size for Thermal Stabilization of Plutonium Finishing Plant Metals, Oxides, and Process Residues, 200 West Area, Hanford Site, Richland, Washington (DOE/EIS-0244-FS/SA2) - This SA was prepared to support a determination on the need for additional NEPA analysis regarding increasing the amount of plutonium thermally stabilized per batch at PFP. Based on the SA, DOE determined that no additional NEPA analysis was required. The SA was signed August 2, 1999.

Supplement Analysis: Supplement Analysis, Project W-460, Plutonium Finishing Plant Plutonium Stabilization and Packaging System, 200 West Area, Hanford Site, Richland, Washington (DOE/EIS-0244-FS/SA3) - This SA was prepared to support a determination on the need for additional NEPA analysis regarding enhanced stabilization, packaging, and storage capabilities for plutonium oxides and metals at the PFP. Based on the SA, DOE determined that no additional NEPA analysis was required. The SA was signed March 9, 1999.

Supplement Analysis: Supplement Analysis, Changes to the Immobilization Alternative, Plutonium Finishing Plant, 200 West Area, Hanford Site, Richland, Washington (DOE/EIS-0244-FS/SA4) - This SA was prepared to support a determination on the need for additional NEPA analysis regarding the use of an alternate method (direct packaging of plutonium-bearing materials in the pipe-container-in-drum [i.e., 'pipe-and-go']) for packaging all or part of bulk plutonium-bearing materials. Based on the SA, DOE determined that no additional NEPA analysis was required. The SA was signed August 18, 2000.

Supplement Analysis: Supplement Analysis, Magnesium Hydroxide Precipitation Process at the Plutonium Finishing Plant, Metals, 200 West Area, Hanford Site, Richland, Washington (DOE/EIS-0244-FS/SA5) - This SA was prepared to support a determination on the need for additional NEPA analysis before stabilization of all PFP plutonium-bearing solutions via a magnesium hydroxide precipitation process (beyond the 20 percent addressed in the ROD) is performed. Based on the SA, DOE determined that no additional NEPA analysis was required. The SA was signed September 22, 2000.

Current Status: $\quad$ DOE is implementing decisions described in the ROD and conducting activities addressed in the Supplement Analysis documentation.

DOE/EIS-0245 Management of Spent Nuclear Fuel From the K-Basins at the Hanford Site, Richland, Washington, final (61 FR 3922)

Background: This EIS analyzes the potential environmental consequences related to the management alternatives for spent nuclear fuel presently stored at the $100-\mathrm{K}$ Area basins. These alternatives, in addition to the No Action Alternative, include enhanced $\mathrm{K}$ Basin storage, new wet storage, new dry storage, and processing (domestic and foreign). The final range of alternatives in the EIS and consistent with the Implementation Plan.

Approximately 2,100 metric tons (2,315 tons) of SNF are stored in water basins in the Hanford Site $100-\mathrm{K}$ East and 100-K West Area reactors. This SNF is principally metallic uranium, but also includes about 5 metric tons ( 5.5 tons) of plutonium and 
about 1 metric ton (1.1 ton) of radioactive fission products. Most of this fuel is from the operation of the $\mathrm{N}$ Reactor. Some of the fuel is damaged and has corroded and become radioactive sludge. Fuel in the $\mathrm{KE}$ Basin is stored in open canisters; corrosion products (sludge) have fallen to the floor of the basin. Fuel in the KW Basin is stored in sealed canisters so any sludge is contained in the canisters. The KE Basin has leaked water and radionuclides to the soil beneath the basin, but neither basin is believed to be leaking now.

Alternatives: $\quad$ The proposed action is to take expeditious action to reduce risks to public health and the environment by removing spent nuclear fuel from the $\mathrm{K}$ Basins and, subsequently, to take action to manage the spent nuclear fuel in a safe and environmentally sound manner for up to 40 years until ultimate disposition decisions are made and implemented.

The proposed alternatives include the following:

- No Action

- Enhanced K Basin storage

- New wet storage

- Drying/passivation (conditioning) with dry storage

- Calcination with dry storage

- Onsite processing

- Foreign processing.

The preferred alternative is drying/passivation with dry vault storage, incorporating the following:

- Remove K Basin spent nuclear fuel from existing canisters, clean, and desludge

- Repackage the spent nuclear fuel into fuel baskets designed for multicanister overpacks (MCOs) that would include provision for water removal, spent nuclear fuel conditioning, and criticality control

- After loading spent nuclear fuel into the MCOs, welding the top, and draining an MCO through small penetrations on the top, initially dry the spent nuclear fuel under vacuum, flood the MCO with an inert gas, seal the penetrations, and place the MCO into a transportation cask

- Transport the sealed MCOs in these casks via truck to the Canister Storage Building (CSB) site in the 200 East Area, and provide for temporary vented staging as necessary

- Vacuum condition the spent nuclear fuel in the MCOs, as soon as practicable, heating the spent nuclear fuel to remove water that is chemically bound to the spent nuclear fuel and canister corrosion products, and to dissociate any reactive uranium hydride

- Following conditioning, weld-seal the spent nuclear fuel in an inert gas in the MCOs for dry interim storage in a vault for up to 40 years 
- Collect the sludge removed from the basins and disposition as waste in the DST System after removal from the basin

- Collect the debris from the basins and dispose of the debris as low-level waste in existing low-level waste burial grounds

- Remove and transport contaminated basin water to the 200 Area Effluent Treatment Facility for final disposal at the 200 Area State-Approved Land Disposal Site, and replace the contaminated basin water with clean water, maintaining basin water levels

Eventually all basin water would be removed as part of facility deactivation activities. The principal factors influencing the choice of drying/passivation with vault storage as the preferred alternative include speed of implementation, improved stability of the SNF, life-cycle cost, and beneficial reuse of an existing (but incomplete CSB) structure.

ROD:

The ROD was published in the Federal Register March 15, 1996 (61 FR 10736).

Basis for the ROD Decision: Based on consideration of environmental impacts, costs, compliance requirements, engineering practicability, worker and public health and safety, and on comments received on the draft EIS, DOE will implement the preferred alternative with two modifications.

ROD Decision: The preferred alternative will involve removing the spent nuclear fuel from the basins, vacuum drying, conditioning and sealing the spent nuclear fuel in inert-gas filled canisters for dry vault storage for up to 40 years pending decisions on its ultimate disposition. The preferred alternative also calls for transfer of the basin sludge to DST System for management, disposal of non-spent nuclear fuel basin debris in a low-level burial ground, disposition of the basin water at the 200 Area State-Approved Land Disposal Site, and deactivation of the basins pending decommissioning.

The first modification is with respect to sludge management. In the preferred alternative, sludge is to be dispositioned as waste in the DST System. However, while in the basins, the sludge will continue to be managed as spent nuclear fuel. Should it not be possible to put the sludge into the DST System, the sludge either will continue to be managed and treated as spent nuclear fuel, or grouted and packaged to meet the solid waste burial ground waste acceptance criteria. The impacts of alternate sludge management were analyzed in the FEIS and are small. By mass, the sludge is about $0.5 \%$ of the spent nuclear fuel and impacts of continuing to manage the sludge as spent nuclear fuel would be negligible by comparison.

The second modification is with respect to the timing of the placement of the MCOs into the transportation casks. In the preferred alternative, the fuel baskets would be loaded into the MCO's, drained, and vacuum dried before placement in the transportation casks. However, placing the MCOs in the transportation casks before loading the fuel baskets into the MCOs would reduce the exposure of personnel to radiation during draining and vacuum drying.

The DOE selected the preferred alternative principally because this will alleviate concerns for protection of workers, public health and safety, and the environment (by 
expeditious removal of the spent nuclear fuel from the vicinity of the Columbia River). The preferred alternative will use a partially completed existing facility (the CSB), will have few, if any, impacts on the physical environment (minimal new construction), and will be implemented at a cost on par with or substantially less than that of the other alternatives.

Supplement Analysis: Environmental Effects of Changes in DOE's Preferred Alternative for Management of Spent Nuclear Fuel from $K$ Basin

(DOE/EIS-0245-SA1) - This SA was prepared to support a determination on the need for additional NEPA analysis as a result of deleting the hot conditioning/passivation step from the preferred alternative selected in the ROD. Based on the SA, DOE determined that no additional NEPA analysis was required. The SA was signed August 27, 1998.

Current Status: Activities described in the ROD have been, and are being, implemented.

\section{DOE/EIS-0250 Geologic Repository for the Disposal of Spent Nuclear Fuel and High-Level Radioactive Waste at Yucca Mountain}

The Notice of Availability for the Draft EIS was issued in August 1999 (64 FR 44200), with public comment invited from August 13, 1999 through February 9, 2000. The Draft EIS provides information on potential environmental impacts that could result from a proposed action to construct, operate, and monitor, and eventually close a repository for the disposal of spent nuclear fuel and high-level radioactive waste (including Hanford-generated wastes) at Yucca Mountain in Nevada.

\section{DOE/EIS-0259 Disposal of Decommissioned, Defueled Cruiser, Ohio Class, and Los Angeles Class Naval Reactor Plants, final.}

Background: $\quad$ As of the end of 1994, the U.S. Navy had 99 nuclear-powered submarines and 13 nuclear-powered surface ships in operation. Today, over $40 \%$ of the Navy's principal combatants are nuclear-powered.

A nuclear-powered ship is constructed with the nuclear power plant inside a section of the ship called the reactor compartment. The components of the nuclear power plant includes a high-strength steel reactor vessel, heat exchangers (steam generator), and associated piping, pumps, and valves. Each reactor plant contains over 100 tons of lead shielding, part of which is made radioactive by contact with radioactive material or by neutron activation of impurities in the lead.

Before a ship is taken out of service, the spent fuel is removed from the reactor pressure vessel of the ship in a process called defueling. This defueling removes all of the fuel and most of the radioactivity from the reactor plant of the ships. The handling and disposal of spent fuel is not the subject of this EIS.

Alternatives: $\quad$ Preferred Alternative - Land burial of the entire reactor compartment at the Low-Level Burial Grounds on the Hanford Site. 
- The reactor compartments would be prepared for shipment at Puget Sound Naval Shipyard, shipped to and buried on the Hanford Site in the Low-Level Burial Grounds. The pre-LOS ANGELES Class submarine reactor compartments would be disposed in the 218-E-12B Burial Ground in the 200 East Area.

No Action Alternative - Protective Waterborne Storage for an Indefinite Period - A ship can be placed in floating protective storage for an indefinite period. Nuclear-powered ships also can be place into storage for a long time without risk to the environment. However, this protective storage does not provide a permanent solution for disposal of the reactor compartments from these nuclear-powered ships. Thus, this alternative does not provide permanent disposal.

Disposal and Reuse of Subdivided Portions of the Reactor Plant - In general, disposal and reuse of subdivided portions of the reactor compartments would expand and build on operations and processes in use at Naval Shipyards to overhaul ships and recycle nonradioactive portions of decommissioned ships. It would require large-scale changes in terms of the numbers and size of components to be processed.

Indefinite Storage Above Ground at the Hanford Site - In this alternative, reactor compartments would be stored indefinitely on the Hanford Site. This alternative is similar to the preferred alternative through shipment of the reactor compartments to the 218-E-12B Burial Ground. However, as in the No Action alternative, storage is not a disposal alternative. Such storage would only defer the need to permanently disposition the radioactive, hazardous, and $\mathrm{PCB}$ waste contained by the reactor compartments.

Other Alternative - The following alternatives were eliminated from detailed evaluation:

- Sea disposal

- Land disposal of entire reactor compartments at other sites

- Permanent above ground disposal on the Hanford Site.

ROD:

A ROD was published in the Federal Register August 9, 1996 (61 FR 41596). Based on consideration of environmental impacts, costs, compliance requirements, engineering practicability, worker and public health and safety, and on comments received on the draft EIS, the preferred alternative was selected.

An EIS entitled Disposal of Decommissioned, Defueled Naval Submarine Reactor Plants was prepared by the Department of the Navy, as the lead agency, with DOE as a cooperating agency. The ROD to the aforementioned EIS was published in the Federal Register in December 1984, which provided NEPA documentation for pre-Los Angeles Class submarine reactor plants (refer to DOE/EIS-0222).

Current Status: $\quad$ Activities described in the ROD have been, and are being, implemented. Submarine reactor compartments have been, and will be, transported for disposal at the 218-E-12B Low-Level Burial Ground, a 70-hectare (173-acre) waste disposal unit in the 200 East Area. To date, approximately 80 submarine reactor compartments have been transported safely and disposed in one area of this burial ground. 
DOE/EIS-0276 Interim Storage of Plutonium at the Rocky Flats Environmental Technology Site

The Notice of Intent to prepare this EIS was published in the Federal Register on July 17, 1996. The public scoping period closed August 16, 1996. The alternatives being proposed for consideration in the EIS include transportation and storage of weapons-useable fissile materials to other DOE sites, including Hanford. The EPA NOA appeared in the November 21, 1997 Federal Register (62 FR 62303) and the DOE NOA was published in the November 25, 1997 Federal Register (62 FR 62761). Public hearings were held in December at Rocky Flats, Savannah River, and Los Alamos.

Current Status: No Final EIS has been issued.

\section{DOE/EIS-0283 Surplus Plutonium Disposition}

Background: $\quad$ An EIS was prepared, tiering from the Storage and Disposition of Weapons-Usable Fissile Materials Programmatic Environmental Impact Statement (Storage and Disposition PEIS, DOE/EIS-0229) issued in December 1996, and the associated ROD (62 FR 3014), issued on January 14, 1997.

The EIS examined reasonable alternatives and potential environmental impacts for the proposed siting, construction, and operation of three types of facilities for plutonium disposition. The first is a facility to disassemble and convert pits (a nuclear weapons component) into plutonium oxide suitable for disposition. As explained in the January 1997 ROD, this pit disassembly and conversion facility will be located at either DOE's Hanford Site, Idaho National Engineering and Environmental Laboratory (INEEL), Pantex Plant, or Savannah River Site (SRS). The second is a facility to immobilize surplus plutonium in a glass or ceramic form for disposition in a geologic repository pursuant to the Nuclear Waste Policy Act. This second facility will be located at either the Hanford Site or SRS, and will include a collocated capability to convert non-pit plutonium materials into a form suitable for immobilization. The EIS discusses various technologies for immobilization. The third type of facility will fabricate plutonium oxide into mixed oxide (MOX) fuel. The MOX fuel fabrication facility would be located at either the Hanford Site, INEEL, Pantex, or SRS. MOX fuel would be used in existing commercial light water reactors in the U.S., with subsequent disposal of the spent fuel in accordance with the Nuclear Waste Policy Act. Some MOX fuel also could be used in Canadian deuterium uranium (CANDU) reactors depending on negotiation of a future international agreement among Canada, Russia, and the U.S. The EIS discusses D\&D of the three facilities.

ROD: $\quad$ The ROD was published in the Federal Register (65 FR 1608) January 11, 2000. DOE decided to implement a program to provide for the safe and secure disposition of up to 50 metric tons of surplus plutonium as specified in the Preferred Alternative of the EIS.

Current Status: $\quad$ DOE is pursuing implementation of the decisions addressed in the ROD. 
Background: An EIS has been prepared by the Bonneville Power Administration (Bonneville), which provides program-wide direction for how Bonneville will manage vegetation on rights-of-way and at facilities.

The EIS proposes various alternatives responding to Bonnevilles need to increase program efficiency and consistency in keeping vegetation a safe distance away from electric power facilities and controlling noxious weeds. The EIS examines the advantages and disadvantages of herbicide use, and to what extent herbicides could and/or should be used. The Integrated Vegetation Management concept (a strategy to cost-effectively control vegetation with the most benign overall long-term effect on public health and safety and the ecosystem) is considered in the evaluation of alternatives.

ROD: $\quad$ The Record of Decision was signed July 28, 2000 (65 FR 48490).

Current Status: Activities described in the ROD are being implemented.

DOE/EIS-0286 Hanford Site Solid Waste (Radioactive \& Hazardous) Program EIS

Background: $\quad$ On 5/16/97, the Acting Manager-RL determined that an EIS was the appropriate level of NEPA review. The draft Notice of Intent was sent to EM-1 on 6/30/97 for approval. EH gave the SW EIS the EIS number 0286. The NOI was approved by EH-1 on 10/21/97 and appeared in the FR on 10/27/97 (62 FR 55615). Public scoping meetings were held in Richland on November 12, 1997 and in Pendleton, Oregon on November 13, 1997. The State of Oregon requested an extension of the public scoping period from December 11, 1997 to January 30,1998, and requested additional public meetings. In response to this request the comment period was extended to January 30, 1998. The Notice of Extension appeared in the December 11, 1997 Federal Register (62 FR 65254). A letter was received from the Yakama Indian Nation (YIN) requesting they be co-preparers of the EIS. After a meeting between RL and the Yakama Technical Staff, the YIN sent a second letter asking for co-operating agency status. The extended scoping period closed January 30,1998. Written comments were received, including comments from the Washington State Department of Ecology and the Oregon Department of Energy. In April RL accepted the YIN as a consulting agency in the preparation of this EIS. Work has been focussed on defining the inventory of wastes to be addressed in the EIS. A letter was signed by the RL-NCO on August 20, 1998 inviting the YIN to participate in the EIS preparation meetings.

Current Status: The draft EIS is anticipated to be issued in FY 2001.

\section{DOE/EIS-0287 Idaho High-Level Waste and Facilities Disposition}

Background: $\quad$ An Idaho High-Level Waste and Facilities Disposition Draft EIS has been prepared which analyzes the potential environmental consequences of managing two waste types at the Idaho National Engineering and Environmental Laboratory. The two types are high-level waste in a calcine form and liquid mixed transuranic waste (historically known as sodium bearing waste and newly generated liquid waste). The 
draft EIS also analyzes the disposition of existing and proposed high-level waste facilities after their missions have been completed. The waste processing alternatives are No Action, Continued Current Operations, Separations, Non-Separations, and Minimum Processing. The facilities disposition alternatives are No Action, Clean Closure, Performance-Based Closure, Closure to Landfill Standards, Performance-Based Closure with Class A Grout Disposal, and Performance-Based Closure with Class C Grout Disposal. The period of analysis for actions considered in the draft EIS is from 2000 to 2095. For residual contamination and waste disposal, DOE analyzed potential impacts over 10,000 years. The Hanford Site's Tank Waste Remediation System is an integral consideration in dealing with the disposition of high-level wastes.

Current Status: $\quad$ The Final EIS is being prepared, and is expected to be completed in Fiscal Year 2001.

\section{DOE/EIS-0306 Treatment and Management of Sodium-Bonded Spent Nuclear Fuel}

Background: This EIS considers environmental impacts of proposed treatment and management of sodium-bonded SNF, including some former FFTF fuel now stored at Hanford. The Notice of Intent to prepare the EIS was issued on February 22, 1999 (64 FR 8553) and scoping meetings were held. The Draft EIS Notice of Availability was issued July 30, 1999 (64 FR 41420). Public meetings were held in South Carolina, Idaho, and Virginia. Public comment period closed 9/13/99. The Final EIS was issued in July 2000.

Current Status: A ROD is anticipated to be issued in Fiscal Year 2001.

DOE/EIS-0310 Programmatic Environmental Impact Statement for Accomplishing Expanded Civilian Nuclear Energy Research and Development and Isotope Production Missions in the United States, Including the Role of the Fast Flux Test Facility

On August 18, 1999 the Secretary of Energy announced that an EIS would be prepared to analyze the impacts of FFTF as a next step in determining the future of the reactor. A Notice of Intent was issued in the Federal Register on September 15, 1999 (64 FR 50064). As stated in the NOI summary, this PEIS will analyze the potential environmental impacts of alternative ways to meet the projected irradiation needs for the next 35 years by enhancing the existing infrastructure as follows:

(1) Resuming FFTF operation, (2) constructing and operating a research reactor at a generic DOE site, and (3) constructing and operating one or more neutron accelerators at a generic DOE site. In addition, the PEIS will analyze the potential environmental impacts of meeting the projected mission needs to the extent possible using existing reactor and neutron accelerator facilities.

Current Status: $\quad$ On 9/10/99, a Notice of Intent to prepare an EIS was published in the Federal Register (64 FR 50064). Scoping meetings were held from 10/13/99-10/27/99.

The Notice of Availability for the Draft EIS was issued 7/28/00 (65 FR 46443). Public comment period ended 9/18/00. 
The Washington State Departments of Health and Ecology determined in February 1997, that an EIS must be prepared under the State (of Washington) Environmental Policy Act (SEPA) before the State can make several key environmental decisions regarding the facility. These decisions include: approval of a site closure plan, renewal of the operating license, and an amendment to the regulations limiting the receipt of NARM. Public scoping is underway through $3 / 27 / 97$. A public meeting was held on 3/5/97 in Kennewick at the Ecology office. Ecology and Health have invited RL to consult with them on issues, concerns, and potential impacts that should be considered in the EIS. A meeting was held on 3/25/97 between Ecology, Health and RL NEPA staff to discuss issues and concerns. RL sent a response letter to DOH and Ecology on 4/8/97 outlining DOE's issues and concerns and RL's role. Ecology and Health have selected an EIS preparation contractor.

Current Status: A draft EIS was issued for comment in August 2000. A Final EIS is anticipated to be issued in 2001 . 
HNF-SP-0903, Rev. 7

This page intentionally left blank. 


\subsection{CERCLA ACTIVITIES AND NEPA}

The Comprehensive Environmental Response, Compensation, and Liability Act (CERCLA) of 1980 requires remediation of sites where there has been the release or threat of release of hazardous substances. The CERCLA process for evaluating remediation alternatives includes evaluating and comparing each alternative against nine criteria including overall protection of human health and the environment, long-term effectiveness, and short-term effectiveness. These criteria address many of the elements that would be addressed in a NEPA evaluation. Overall protection of human health and the environment evaluates whether an alternative adequately protects human health and the environment. Long-term effectiveness considers the magnitude of the residual risk (risk to human health or the environment from untreated waste or treatment residuals remaining at the conclusion of remedial activities) and the adequacy and reliability of controls needed to manage untreated wastes or treatment residuals. Short-term effectiveness evaluates impacts occurring during remediation such as risks to the community (e.g., from air emissions), risks to workers, and risks to the environment (e.g., from activities occurring in ecologically-sensitive habitats).

DOE recognizes that the CERCLA evaluation process overlaps significantly with the NEPA evaluation process. To coordinate and streamline the processes, DOE Order 451.1A states that DOE CERCLA documents shall "incorporate NEPA values, such as analysis of cumulative, off-site, ecological, and socioeconomic impacts, to the extent practicable." Thus, with the specific addition of NEPA values,

CERCLA documents can be used to satisfy NEPA requirements. This order has been met at the Hanford Site by adding a section on 'NEPA Considerations' to CERCLA documents, primarily engineering evaluations/cost analyses (EE/CA) and feasibility studies (FS). The overall effect has been to reduce duplicative documentation while at the same time providing more comprehensive documents for public review.

The following lists identify EE/CAs and FSs that have incorporated NEPA values.

\section{$\mathrm{EE} / \mathrm{CAs}$}

Engineering Evaluation/Cost Analysis for the 100-B/C Area Ancillary Facilities and the 108-F Building, DOE/RL-96-85, Rev. 0

Engineering Evaluation/Cost Analysis for the 100-N Area Ancillary Facilities and Integration Plan, DOE/RL-97-22, Rev. 1

Engineering Evaluation/Cost Analysis for 100-N Area Waste, BHI-00785, Rev. 0

Engineering Evaluation/Cost Analysis for the 105-DR and 105-F Reactor Facilities and Ancillary Facilities, DOE/RL-98-23, Rev. 0

Engineering Evaluation/Cost Analysis for the 233-S Plutonium Concentration Facility, DOE/RL-96-93, $\operatorname{Rev}, 0$

Engineering Evaluation/Cost Analysis for the 105-D Reactor Facilities and Ancillary Facilities, DOE/RL-2000-45, Rev. 0

Engineering Evaluation/Cost Analysis for the 105-H Reactor Facilities and Ancillary Facilities, DOE/RL-2000-46, Rev. 0 
Engineering Evaluation/Cost Analysis for the 331-A Virology Laboratory Building, DOE/RL-99-64, Rev. 0

Engineering Evaluation/Cost Analysis for the 105-N Area Ancillary Facilities and Integration Plan, DOE/RL-97-22, Rev. 0

FSs

Phase I Feasibility Study for the Canyon Disposition Initiative, DOE/RL-97-11, Rev. 1

Corrective Measures Study for the 100-NR-1 and 100-NR-2 Operable Units, DOE/RL-95-111, Rev. 0

100-NR-1 Treatment, Storage, and Disposal Units Corrective Measures Study/Closure Plan,

DOE/RL-96-39, Rev. 0

100-HR-3 Operable Unit Focused Feasibility Study, DOE/RL-94-67, Rev. 0

100-KR-4 Operable Unit Focused Feasibility Study, DOE/RL-94-48, Rev. 0

100 Area Source Operable Unit Focused Feasibility Study, DOE/RL-94-61, Rev. 0

Remedial Investigation/Feasibility Study Report for the 300-FF-5 Operable Unit, DOE/RL-94-85, Rev. 0

Phase III Feasibility Study Report for the 300-FF-1 Operable Unit, DOE/RL-94-49, Rev. 0

Remedial Investigation and Feasibility Study Report for the Environmental Restoration Disposal Facility, DOE/RL-93-99, Rev. 1

Focused Feasibility Study for the 300-FF-2 Operable Unit, DOE/RL-99-40, Rev. 0

100 Area Burial Grounds Focused Feasibility Study, DOE/RL-98-18, Rev. 0

Focused Feasibility Study for the K Basins Interim Remedial Action, DOE/RL-98-66, Rev. 0 
HNF-SP-0903, Rev. 7

\subsection{REFERENCES}

45 FR 21676, 1980, "Surry Steam Generator Project Environmental Assessment," Federal Register, April 2.

45 FR 46155, 1980, "Double-Shell Tanks for Defense High-Level Radioactive Waste Storage, Hanford Site, Richland, Washington," Federal Register, July 9.

45 FR 56125, 1980, "Finding of No Significant Impact, 100 F-Area Decommissioning Program; Hanford Site," Federal Register, August 22.

46 FR 26677, 1981, "Program of Research and Development for Management and Disposal of Commercially Generated Radioactive Wastes; Record of Decision," Federal Register, May 14.

47 FR 36276, 1982, "Record of Decision to Decommission the Shippingport Atomic Power Station," Federal Register, August 19.

47 FR 40820, 1982, "Finding of No Significant Impact and Notice of Availability of Environmental Assessment for the Conduct of Detailed Site Through Construction of an Exploratory Shaft on the Hanford Site," Federal Register, September 16.

48 FR 21993, 1983, "Record of Decision to Resume Operation of Purex and Uranium Oxide Plant Facilities; Hanford Site, Richland, Washington," Federal Register, May 16.

50 FR 20489, 1985, "Notice of Intent to Prepare an Environmental Impact Statement on Decommissioning the Eight Shutdown Production Reactors Located at the Hanford Site Near Richland, Washington," Federal Register, May 16.

53 FR 12449, 1988, "Disposal of Hanford Defense High-Level, Transuranic, and Tank Wastes, Hanford Site, Richland, Washington; Record of Decision (ROD)," Federal Register, April 14.

53 FR 50444, 1988, "Proposed Finding of No Significant Impact; SP-100 GES Test Site; Hanford Site, Richland, Washington," Federal Register, December 15.

54 FR 18325, 1989, "Availability of Draft Environmental Impact Statement on Decommissioning of Eight Surplus Production Reactors at the Hanford Site, Richland, Washington," Federal Register, April 28.

54 FR 39564, 1989, "Finding of No Significant Impact; SP-100 GES Test, Hanford Site, Richland, Washington," Federal Register, September 27.

58 FR 48509, 1993, "Eight Surplus Production Reactors Decommissioning; Hanford Site, Richland, Washington," Final Environmental Impact Statement, Federal Register, September 16, 1993.

60 FR 28680, "Programmatic Spent Nuclear Fuel Management and Idaho National Engineering Laboratory Environmental Restoration and Waste Management Programs, Part III," ACTION: Record of Decision, Federal Register, Thursday, June 1, 1995.

60 FR 54221, "Final Environmental Impact Statement for the Safe Interim Storage of Hanford Tank Wastes at the Hanford Site, Richland, WA. ACTION: Record of Decision, Federal Register, Friday, October 20, 1995. 
60 FR 61687, "Safe Interim Storage of Hanford Tank Wastes, Hanford Site, Richland, WA. ACTION: Record of Decision, Federal Register, Friday, 1, 1995.

61 FR 3922, "Availability of the Final Environmental Impact Statement for Management of Spent Nuclear Fuel from the K Basins at the Hanford Site, Richland, WA. ACTION: Notice of Availability of Final Environmental Impact Statement, Federal Register, Friday, February 2, 1996.

61 FR 10736, "Management of Spent Nuclear Fuel from the K Basins at the Hanford Site, Richland, WA. ACTION: Notice of Record of Decision, Federal Register, Friday, March 15, 1996.

61 FR 36352, "Record of Decision for Plutonium Finishing Plant Stabilization Final Environmental Impact Statement, Hanford Site, Richland, WA. ACTION: Notice of Availability of Record of Decision, Federal Register, Wednesday, July 10, 1996.

Chatters, J. C., and N. A. Cadoret, 1990, Archaeological Survey of the 200 East and 200 West Areas, Hanford Site, Washington, PNL-7264, Pacific Northwest Laboratory, Richland, Washington.

Comprehensive Environmental Response, Compensation, and Liability Act of 1980, 42 USC 9601 et seq.

DOE, 1987, Final Environmental Impact Statement: Disposal of Hanford Defense High-Level, Transuranic and Tank Wastes, Hanford Site, Richland, Washington, 5 vols, DOE/EIS-0113, U.S. Department of Energy, Washington, D.C.

DOE, 1988, Environment, Safety, and Health Program for Department of Energy Operations for Richland Operations, DOE Order 5480.1 A, U.S. Department of Energy, Washington, D.C.

Ecology, EPA, and DOE, 1996, Hanford Federal Facility Agreement and Consent Order, as amended, Washington State Department of Ecology, U.S. Environmental Protection Agency, and U.S. Department of Energy, Olympia, Washington. 


\section{DISTRIBUTION}

U.S. Department of Energy

Headquarters, Washington D.C.

E. B. Cohen

Room 3E-080

Forrestal Building

U.S. Department of Energy,

Richland Operations Office

P. F. X. Dunigan, Jr. (5)

A5-15

Reading Room

Bechtel Hanford, Inc.

R. J. Landon

$\mathrm{H} 0-02$

Fluor Hanford

R. H. Engelmann

Gl-30

M. T. Jansky (5)

G1-30

Pacific Northwest National Laboratory

M. D. McKinney

K8-03

Hanford Technical Library

P8-55

Lockheed Martin Services, Inc.

Central Files

B1-07

DPC

H6-08

EDMC (2)

H6-08

DynCorp Tri-Cities Services, Inc.

C. J. Grando

G3-26

Jacobs Engineering

D. Nichols

A0-25

Distr-1 
HNF-SP-0903, Rev. 7

This page intentionally left blank.

Distr-2 